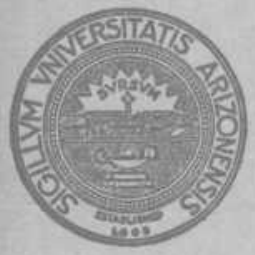

Alnuturgity of Ariznna College of Agriculture Agricultural Experiment Station

\title{
THE LIFE HISTORIES AND ECOLOGY OF JACK RABBITS, \\ LEPUS ALI.ENI AND LEPUS CALIFORNICUS SSP., IN RELATION TO GRAZING IN ARIZONA
}

\author{
$\mathrm{By}$ \\ Charles T. Vorhies, Entomologist, \\ Agricultural Experiment Station, \\ University of Arizona, \\ AND \\ WALtTER P. TAyzor, Senior Biologist, \\ United States Department of Agriculture, \\ Bureau of Biological Survey.
}




\section{ORGANIZATION}

\section{BOARD OF REQENTS}

HIS EXOEI,LENCY, B. B. MOEXR, M.D., Governor (Ex-ofticio)

Phoenix

HON. FERMAN E. HENDRTX, Ph.D., State Supt. of Publie Instruetion (Ex-ofiliofo) ......... Phoenix Appointed Members

HON, ROBERT F. TALIY, B.S., M.E., President nerome

HON. CHARLKS M, LAYTON . M M.

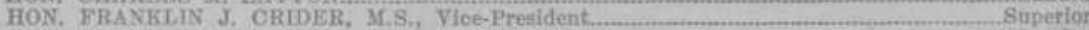

HON. THEODORA MARSH

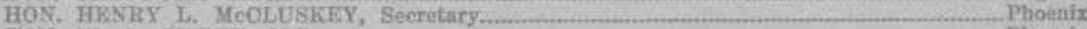

HON, W. 0. SWEKK, M.D . Phoenfx

HON, BVERETT E, EITINWOOD, HA.B......... Phoentx

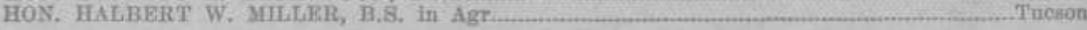

HOMER L. SBANTZ, Ph.D., Se,D.

President of the University

PXPRRDERNT STATION STAFE

PAUL S. BURGESS, Ph.D Director and Dean

AGRICULTURAL CHEMISTRY AND SOILS DEPARTMENT

WHALM T. MeCHORGR, M.S.

- JAMTES F, BREAZEAIE, B.S.

THEOPHIL F. BUEHRER, Ph.D.

gricultural Chemist

HOWARD V. SMITH. M.S.

Biochemist

ROBERT A. GREENE, Ph.D.

Physical Chemist

ALVIN D. AYRES, M.S

F. OSBORN FOSTPR, M.S. Assistant Asrieultural Ohemist (Phoenix) Assistnnt Agricultural Chemist. (Phoenix)

AGRICULTURAL ENGINEERING DEPARTMENT (Irrigation)

GEORAE E. P. BMTTH. C.T., D.Eng.

A grienitural Enginner BAROLD O. SOHW ALEN, B.S. in M.E., M.S. In O.E._........ Associate Asticultural Engineer WILLTAM A. STERNBERGEN, B.S. in C.E................... Assistant Agricuitural Fngineer

AGRONOMY DEPARTMENT

RAIPH S, HAWKTNS, Ph.D.

Agronomist

IAN-A. BRTOGS, M.S

ROBERT L. MATYOOK, Ph.D.

"ARTHUR T. BARTEL, ar.S

ANIMAL HUSBANDRY DEPARTMENT

FRNTEST B. STANTEY, M.8.

EVBRETF I. SCOTT, Ph.D

Acsocinte Amonomint Assintint Agronomist Juntor Agronomist

BOTANY DEPARTMENT JOHN J. THORNBER, M.A.

DAIRY HUSBANDRY DEPARTMENT

WALTER S. CUNNINGHAM, M.S

Animal Hrabandmin RICHARD N. DAVIS, M.8.

Dairy Husbanitmun ENTOMOLOGY AND ECONOMIC ZOOLOGY DEPARTMENT

CHARLES $\mathrm{T}$. VORHIES, Ph.D.

FIMAER D, BALI, PhD

†WALTER. P. TAYT.OR, Ph.D

LAWRTNOE P. WEFRIE, Ph.D

Pntomologist

Ceonomie Zoolnorist

HORTICULTURE DEPARTMENT

ALLFN F. KINNISON, M.S.

DAVID W. ALBERT, MS.

MATCOLM F. WHARTON, M S

Research Biologist

Associate Dairy Husbrendman

AITON H. FINCH, Ph. D.

RORER'T H. HII GFMAN, B.S.

Fortienlturist

tKARL HARRIS, M.S ........

HUMAN NUTRITION DEPARTMENT

MARGARET OAMNACK FMTTH, Ph.D.

GHADY HARTIEY ROEHM, Ph.D

FDITH LANTZ, M.S.

PLANT BREEDING DEPARTMENT

WALKER E, BRYAN, M.S.

EMAS H. PRESSIEY, M.S.

PLANT PATHOLOGY DEPARTMENT

JAMPS 6 . BROWN, Ph.D

RUBPRT B. STRELTS, Ph.D

MIIITON M. EVANS, M.S Assfistant Entamologist Aseociate Hortienituriat (Tempe)
Assigtant Horticulturist.
Assistant Horticulturist Aseociate Horticnituriat (Tempe)
Assiatant Horticulturist
Asistant Horticulturlst Assistant Forticultarist (Temne) Assistant Irrigatton Enginear (Phoenix) LTRY HUSBANDRY DEPARTMENT

HARBY EMBLETON, B.S HUBPRT B, HINDS, M.S.

Nutrition Chemist Asanciate Nutrition Chemiat Amsistant Nutrition Clvemist

RANGE ECOLOGY DEPARTMENT

WIIIIAM G. McCINNIES, Ph. ANDREW A. NICHOL, B.S. I.AURENCE D. LOVE, M.S.

Plant Breeder Associate Plant Breeder

Plant Pathologint Assoofate Plant Pathologint Research Assistant in Plant Patholory Poultry Fusbandman Assiatant Poultry Husbandmen

Pange Ecoloufat Assistant Range Ecologist Research Asslatant in Range Ecologr

IIn cooperation with United States Department of Agriculture, Bureau of Biological Survey. fin cooperntion with United States Department of Agriculture, Buresu of Agricultural Bngineering.

-In cooperation with United States Department of Agriculture, Bureau of Plant Industry. 


\section{CONTENTS}

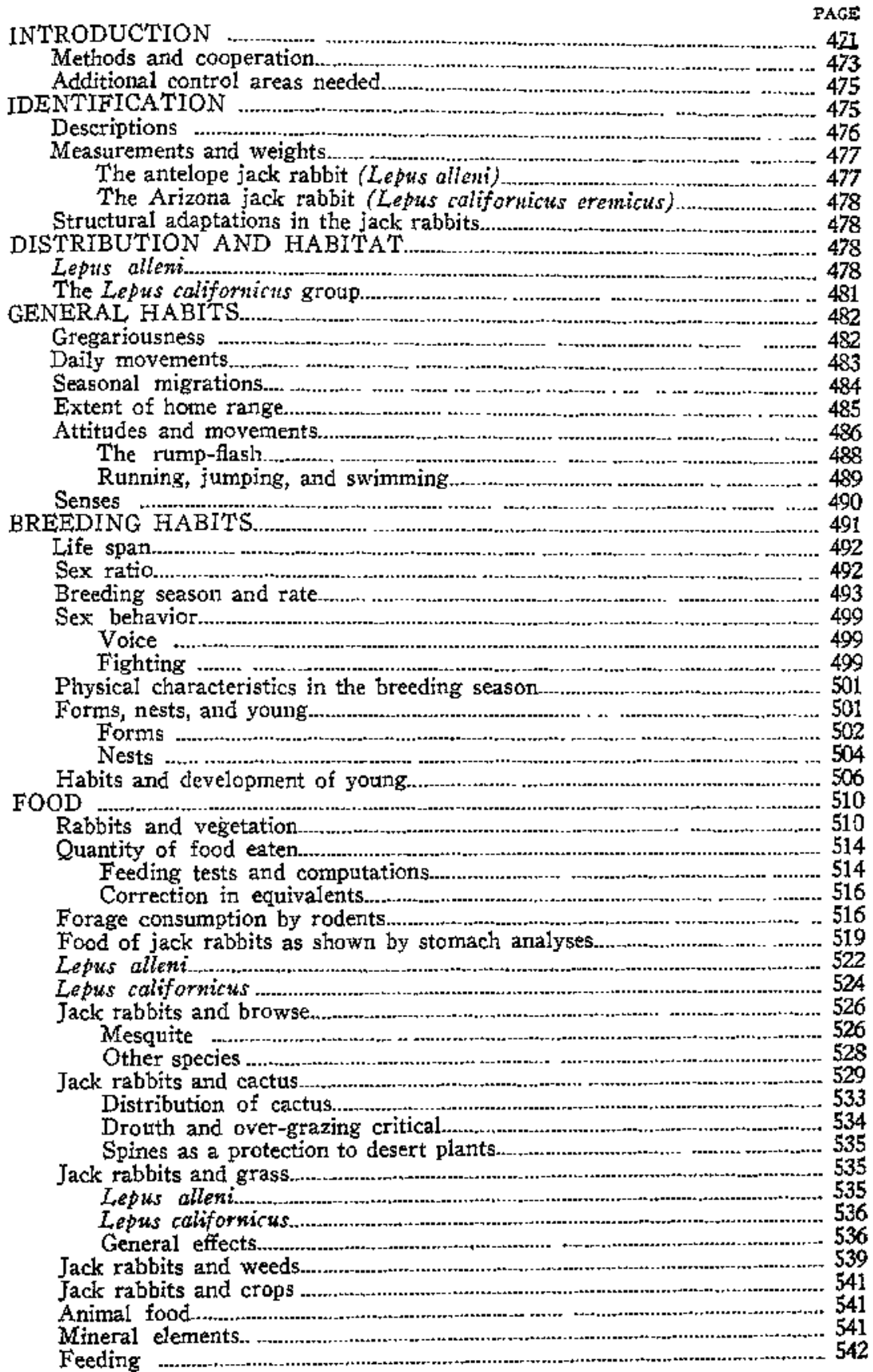




\section{ILLUSTRATIONS}

Fig. 1.-Range, in Arizona, of Lepus alleni compared with that of Lepus califormicus ssp. Lepus californicus occurs all over the state.

Fig. 2.-Percentage consumption of food of L. allcni throughout the year..... 524

Fig. 3.-Percentage consumption of food of L. californicus eremicus throughout the year..

Fig. 4. -Dotted lines show routes traversed in making jack rabbit-cow counts.. $\mathbf{5 5 8}$ Fig. 5-Diagram of bio-physical complex..

\section{PLATES}

Plate 1.. Frontispiece

Plate $2 \ldots$ 487

Plate $3 .$. 503

Plate 4. 507

Plate 5 .. 517

Plate 6 . 520

Plate 7. 521

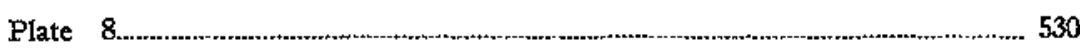

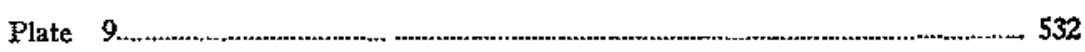

Plate 10

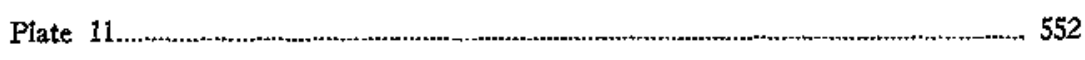

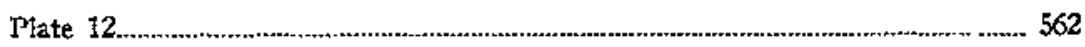




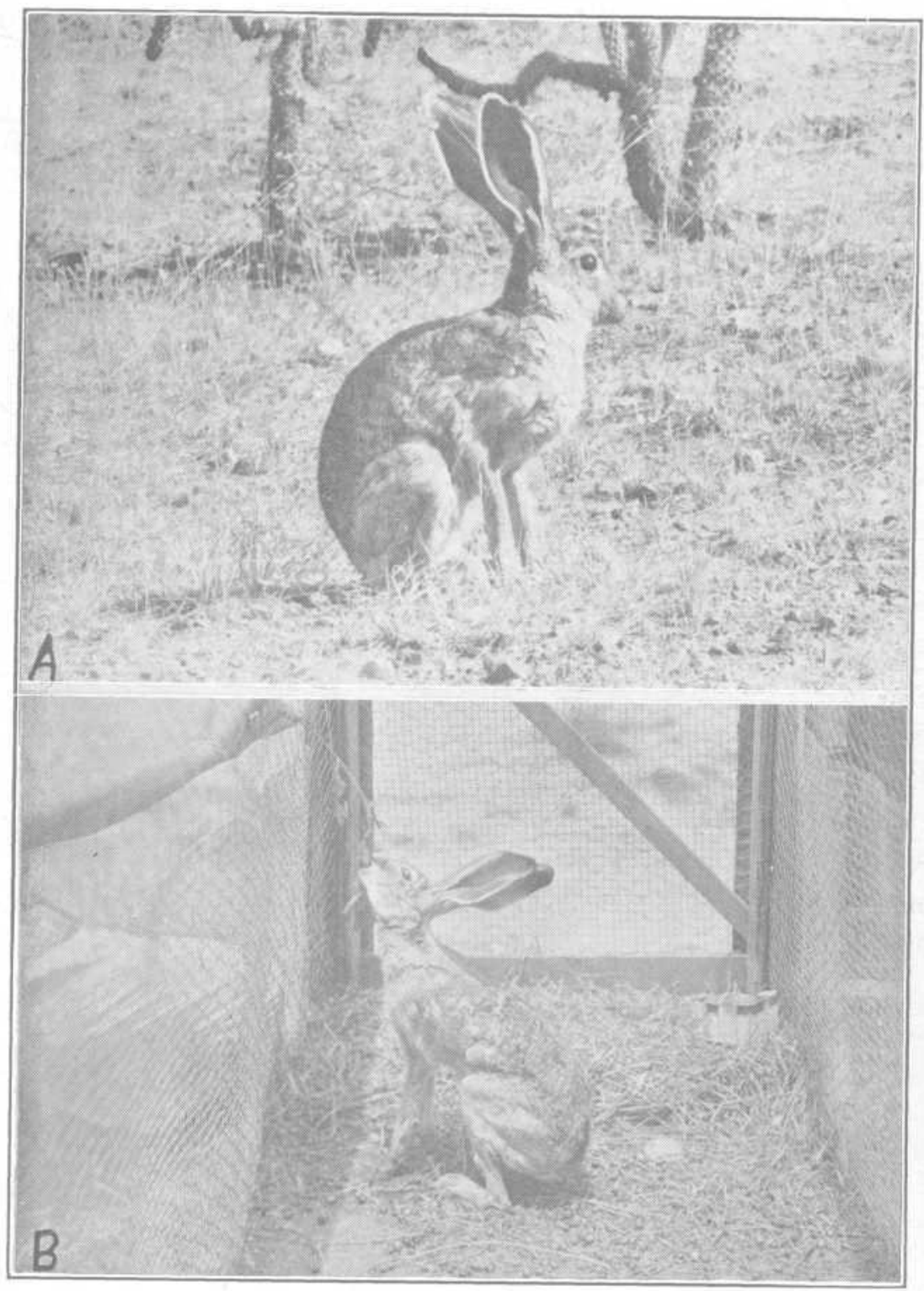

Plate 1,-The jack rabbits of southern Arizona: A, The antelope jack rabbit (Lepus alleni alleni), Santa Rita Experimental Range, near Tucson, Arizona; B, The Arizona jack rabbit (Lepus californicus eremicus), Tucson, Arizona. Note the conspicuotis white-edged ears of alleni, and the black-tipped ears of californicus. 


\section{THE LIFE HISTORIES AND ECOLOGY OF JACK RABBITS, LEPUS ALLENI AND LEPUS CALIFORNICUS SSP., IN RELATION TO GRAZING IN ARIZONA}

$\mathrm{Bx}$

ChARLES T. Vorhiss, Entomologist, Agricultural Experiment Station, University of Arizona, AND

WaLter P. TAYLor, Senior Biologist, United States Department of Agriculture, Burcau of Diological Survey.

\section{INTRODUCTION}

The jack rabbit, in its proper place, is a picturesque and to some extent a trseful citizen. But what, under modern conditions, is its proper place? Not, to be sure, on the alfalfa fields or other crop lands in farming districts. Certainly not in foreign countries or in lands far from its natural area of clistrbution. Stories of bringing the rabbit of Europe into England and the same species into Australia and New Zealand are franght with interest and full of significance. They carry an unmistakable warning to the "introductionists." A critical scientist (Farrow, 1925, p. 104) has gone so far as to suggest that "The passing of England from a forest period into a grassland period may of late have been accelerated by the influence of rabbits." The situation in Australia is still more serious According to Stead (1928, p. 5), "Probably it will be agreed that no single circumstance in the history of Australia has so profoundly affected the economic development of our pastoral and agricultural industries as the introduction of the European wild rabbit." These are strong words. Let us translate them into concretes. The lowly rabbit, a more profound influence on the economic development of the country, at least during the period referred to by Stead, than problems of capital and labor, tariff, immigration, interracial and international relations! The further one goes, however, in the study of conditions on that continent, the more readily he comes to agree that Stead's comment is by no means overdrawn.

Nor do we have to go to foreign countries for illustrations of potential damage by jack rabbits. In the valleys of California, and in the arid lands of the intermountain region, as eastern Oregon, eaştern Washington, Wyoming, Colorado, Idaho, Utah, and Nevada, jack rabbits have not infrequently attained to plague status, warranting, yes, necessitating, drastic control measures as a price of crop security. 
The story is not all unfarorable, however, to our long-eared compadre. Some people use its ample carcass for food, and there is no reason why, with proper precautions, this use should not be extended. The jack rabbit is a "key-industry" species, affording sustenance to a variety of flesh-eating mammals, which otherwise might give more attention to pouttry, lambs, calves, quail, and other game birds, in the conservation of which man has a decided interest.

We must apparently surrender the cherished idea that wild creatures generaily, and in their native habitats, are either wholly good or wholly bad. A broad and open-minded view should be taken toward the lesser inhabitants of our globe. Such an attitude is only fair to our animal colleagues, and more than this, it is the only safe course for ourselves. History shows that mankind has frequently been guitty of policies and practices in reference to natural resources that have resulted in inexcusable waste and have made man hinself poorer. At intervals all our policies for the regulation of natural resources should be given a critical re-examination in the light of the latest information. Only in this way can we be reasonably sure we are giving present and future generations a square deal.

As our knowledge of wild life problems increases, we are compelled to conclude that: (1) problems involving particular animals and plants are different in different places, and should be worked out with full knowledge of local conditions; (2) problems involving particular animals or plants can be solved only when attention is given to the interrelationships existing between the species involved and all other important species. Interrelationships with environment also are of vital importance.

Studies in biology, as with this study of the jack rabbit, can never be up-to-date. Nature's great equation is always changing. Factors are dropped out here and there; others are introduced. It is obvious that many human enterprises affect jack rabhit status - among them:

(1) bringing new lands under irrigation; (2) grazing by livestock; (3) predatory animal and rodent control; (4) deforestation. The research job, in biology, is never done. Published books and papers are at best but progress reports. These facts do not detract from, but rather add to, the need for research and the publication of research.

We would like to be able to answer all the questions that have arisen, and to present, in simple words and clear, formulas for regulating the jack rabbit under all conditions to man's advantage. Unfortunately, such definiteness of statement is impracticable. It is disappointing perhaps, that we have been able merely to open the subject rather than to settle all the problems that have arisen in connection with it. Recall, however, that studies in the wild life field, though now given much less 
financial support, are infinitely more difficult than those, say, in playsics and chemistry. "The motions of the solar system since its beginning are less complicated than the play of a child for a day" (Cattell, 1929, p. 336). It should be remembered, too, that in the long run, biological studies, since they deal with living matter, behavior, population, food, shelter, adaptation, environment, and heredity, promise more. perhaps. for the future welfare of mankind than all other investigations put together. We humans are animals, dependent for our living on other animals and on plants. Studies of individual and community relationships involved in the world of living things should be the most useful as well as the most fascinating pursuit open to mankind.

Field work for the present study of the jack rabbit was done almost exclusively in southern Arizona. Specific conclusions reached apply only in that or closely similar regions. Free use has been nade, however, of available pertinent information that seems to throw any light on the questions that arose during the cotrrse of the study.

\section{METHODS AND COOPERATION}

During the period of his residence in Tucson, Vorhies (since 1915) has taken an interest in the jack rabbits of the vicinity and at intervals has given time to their study in the field. Beginning during short visits in 1918, and continuing during a period of residence beginning in 1922, Taylor has likewise been concerned at intervals with the ecology of the jack rabbit. Field work by the writers has been done both separately and together. Most of the actual investigations have been conducted on the Santa Rita Experimental Range, but personal field work has been done west through California (Vorhies and Taylor), north to central Utah (Taylor), east through Texas (Taylor), and south to Libertad, Hermosillo, and Kino Bay, Sonora, Mexico (Vorbies).

The Santa Rita Experimental Range is a tract of nearly 50,000 acres located at the northwest base of the Santa Rita. Mountains about 35 miles south of Tucson, Arizona. It lies on a bahada* between altitudes of 2,700 and 4,500 feet, and includes a variety of types of vegetation of the semi-arid country.

The Jornada Experimental Range is a similar, but larger, grazing range experiment station near Las Cruces, New Mexico. Both these areas are under the administrative control of the United States Forest Service.

\footnotetext{
*A long, gently sloping land form, isually made tp of contiguons alluvial fans, occurring about the bases of some of the southern Arizona mountains. Bahadas are intermediate between the plains of the valley bottom and foothills. They are ustrally well grassed as compared with lower-lying areas.
} 
Some years ago (Vorhies and Taylor, 1922, p. 3) the Agricultural Experiment Station of the University of Arizona, the United States Biological Survey, the Camegie Institution of Washington, and the United States Forest Service undertook a study of the ecology of the range lands of the Southwest, the work being centered on the Santa Rita Range, and including investigations of the life histories of rabbits and the more important rodents and their relations to vegetation. The present paper is based on this work.

The preparation of this bulletin has been facilitated by a number of workcrs. Dr. Frederic E. Clements, of the Carnegie Institution of Washington, has given active cooperation. Officers of the Sotthwestern Forest and Range Experiment Station, especially G. A. Pearson, director. C. K. Cooperrider, senior range examiner in charge of grazing investigations, and P. B. Lister and Matt Culley (director) of the Santa Rita Experimental Range, have extended uts numerous courtesies, as did also R. L. Hensel and R. R. Hill, former directors. The stockmen who run their cattle on the Santa Rita Range have been helpful in many ways. Special mention, in this connection, should be made of cooperation by Mr. W. D. Parker. Professor McGinnies, of the Department of Range Ecology of the University of Arizona, participated in some of the freld work (charting quadrats, and taking vegetative notes).

MI. E. Mrrsgrave (Forest Service), and D. A. Gilchrist, regional supervisor, rodent and predatory animal control, southwestern district, (Biological Survey) have been helpftul. $\Lambda$ considerable amount of information gathered in New Mexico and Texas has been furnished us by Don A. Spencer of Control-Methods Research, and Shaler E. E. Aldous of the Food Habits Research Laboratory, Biological Survey, Denver, Colorado. Ben E. Foster, leader rodent and predatory animai control, State of Arizona, and Chas. E. Gillham, assistant leader, have cooperated in numerous ways. A number of other Biological Survey workers have furnished important information, among them being: E. E. Horn, John W. Meyer, Joseph Keyes, F. E. Garlough, Leo L. Laythe, James Silver, Thomas B. Murray, Wallace W. Smith, Otto E. Stephl. E. R. Sars, A. E. Gray, John C. Gatlin, Ira N. Gabrielson, Stanley G. Jewett, Laurence C. Whitehead, Cedric R. Landon, George H. Holman, Reuben S. Zimmerman, Leo K. Couch, Theo. H. Scheffer, and O. J. Mirie.

C. C. Sperry of Food Habits Research, Biological Survey, Washington, D. C., under the direction of W. L. McAtee, in charge, did all the painstaking work of analysis of the contents of jack rabbit stomachs.

We have had the active cooperation of the authorities of the University of Arizona, especially President H. L. Shantz, Dr. P. S. Burgess, 
dean and director, College of AgricuIture; Dr. E. D. Ball, former dean, College of Agriculture; and A. A. Nichol and D. M. Gorsuch. Likewise, we have received the most cordial backing and encouragement of Dr. W. B. Bell, principal biologist in charge of the Division of Biological Investigations, Biological Survey, Washington, D. C., Edward A. Preble, assistant in charge, Stanley P. Young, principal biologist in charge of the Division of Predatory Animal and Rodent Control, and of Paul G. Redington, chief of the bureau.

\section{ADDITIONAL CONTROL AREAS IEEDED}

In attempting to determine the role of the jack rabbits on the range we have been impressed with the need, in all such studies, of more adequate control areas. We feel that in any bio-ecological problem, involving the plants, animals, soil, and climate of particular areas, it is desirable and often essential to have control areas of large size, i.e., several hundred or preferably several thousand acres, under natural conditions, to compare with areas subject to various degrees of modification by man. Provision, on the Santa Rita Range. of large areas in each type (semi-desert, mesa, foothill), and embracing, as far as possible, every important condition, free from all grazing by cattle, would help the observer to find the right answers to the questions that are sure to come up in the course of his work. In the absence of such areas the answers will lack something in definiteness and concluiveness. Among the problems to the solution of which large-sized control areas might be expected to contribute are: life histories, soil relations, and food habits of native animals (rodents, birds, insects, etc.); most productive management of range; range rehabilitation: carrying capacity of the range for livestock. game and native rodents: game problems; and erosion on range lands.

\section{IDENTIFICATION}

The jack rabbits may be readily distinguished from other rabbits by their structural characters and habits. Lyon (1904, pp. 386-389) gives detailed keys to the families, genera, and subgenera of the order Lagomorpha to which all rabbits belong, based on dental, cranial and other skeletal characters. It is unnecessary to recapitulate these keys, except to point out that in the skull of the jack rabbits the interparietal is not present as a distinct bone in adult life, while in the cottontails it is present. In this characteristic the cottontails (genus Sylvilagus) resemble the European rabbit and the domesticated varieties of rabbits.

In life the jack rabbits can be readily distinguished from the cottontails of the same region by their entirely different habits. While the 
jack rabbit, on being alarmed, runs with long strides, interrupted by an occasional observation leap, covering much country in a very short space of time, the cottontail, under similar conditions, scuttles hutriedly to cover, htunping along on its relatively short legs, its white tail bobbing up and down with the motion of its body, the animal dodging artfully en route to sheiter, which is seldom far off. The jack rabbit stops in the open, poised for another tun if necessary. The cottontail generally disappears, in a burrow, although an occasional individual ma pause a moment at the entrance to see what is going to happen next.

The dimensions and weights of the jack rabbits afford a ready means of separating them from the cottontails.

\begin{tabular}{|c|c|c|c|}
\hline $\begin{array}{c}\text { Total } \\
\text { lengtli } \\
2(670-553)\end{array}$ & $\begin{array}{c}\text { Tail } \\
\text { vertebrae } \\
58(76-48)\end{array}$ & $\begin{array}{l}\text { Hind } \\
\text { foot } \\
140(150-127)\end{array}$ & $\begin{array}{c}\text { Ear from } \\
\text { notch } \\
162(173-138)\end{array}$ \\
\hline Micus & & & \\
\hline duboni & $71(90-50)$ & $132(145-112)$ & $139(163-127)$ \\
\hline ....... 359 & 51.4 & 84.4 & 58.9 \\
\hline
\end{tabular}

It will be noted that the total length of the cottontail is but 77 percent, the hind foot 75 percent, and ear from notch 54 percent, of those of the smallest measured jack rabhit. The weights, too, are distinctive. While the cottontail weighs but 2-3 pounds, the Arizona jack rabbit weighs on an average 5.5 pounds, while the antelope jack rabbit tips the scales at an average of 8 pounds.

The two jack rabbits indigenous to the Tucson region in southem Arizona (Arizona jack rablit, Lepus califormicus eremicus, and antelope jack rabbit, Lepus alloni alleni) can also be easily distinguished (Plate 1). Their dimensional differences have already been referred to and are further treated on pages 477, 478. An easy field mark for distinguishing the two at a glance is the color of the tips of their very conspicuous ears. While the Arizona jack rabbit has the tip of the ear black for 1 to $11 / 2$ inches, the antelope lacks the black tip.

\section{DESCRIPTIONS}

Excellent descriptions of both the Arizona and the antelope jack rabbits have been published by Nelson (1909, pp. 117-118, 140.141). These descriptions, stupplemented by our own stuclies of the animals in the field, and by additional information here given on the weights. measurements, and structural adaptations of the two species, should suffice to convey at least some notion of their principal characteristics. It is worthy of remark that Nelson regards Lepus alleni as ". . the hand-

* From Nelson, 1909. p. 223. 
somest and most strongly marked of the jack rabbits, its huge ears, long legs, short tail, and bright color completely differentiating it and making it one of the most remarkable and striking of American mammals."

\section{MEASUREMENTS AND WEIGHTS}

External measurements include: Total length: From tip of nose to tip of tail vertebrae, measured before skinning. Tail i'ertebrac: Length from point in angle when tail is bent at right angles to body to tip without hairs. Ear from notch: Length from notch at bottom of external opering to tip exclusive of hairs. Hind foot: Length from heel to tip of longest claw.

It may be noted that alleni is the longest-eared jack rabbit in the United States, its ears being as much as $81 / 4$ inches in total length measured from head to ear tip. Recorded tail measurements of rabbits are less satisfactory than in most mammals owing to the difficulty of making them accurately. They do show, however, that califomicus, notwithstanding its smaller size, has a longer tail than alleni. The tail of californicus averages 12.7 percent of the total length, while the tail of alleni averages but 9.4 percent of its total length.

\section{THE ANTELOPE JACK RABBIT (LEPUS ALLENI ALLENI)}

Average measurements of 53 adult specimens of both sexes taken at various localities in Arizona, mostly on the Santa Rita Range: Total length, 622 millimeters (670-553); tail vertebrae, 58 (76-48); ear from notch, 162 (173-138); hind foot, 140 (150-127). The average weight of 116 individuals of both sexes was 8 pounds $(13-6)$.

Averages of 23 adult females: Total length, 625 millimeters $(660-$ $597)$; tail vertebrae, 59 (76-48); ear from notch, 161 (173-138); hind foot, 141 (150-133). The average weight of 55 adult females was 9 pounds (13-6.4). Excluding the females which were advanced in pregnancy, the average weight was 8 pounds $(10-6.4)$. It is worth noting that the smallest (probably youngest) female recorded as an adtult was already pregnant. On the other hand more than one nonpregnant female was recorded at 10 pounds.

Averages of 30 adult males: Total length, 619 nillimeters (670-553); tail vertebrae, 57 (70-52); ear from notch, 163 (173-146); hind foot, $140(150-127)$. The average weight of 61 adu't males was 8.2 pounds 10.5-6).

On the above showing size and weight differences between the sexes are insignificant. 
THE ARIZONA JACK RABBIT (LEPUS CALIFORNICUS EREMICUS)

Average measturements of 32 adult specimens of both sexes taken in various localities in southern Arizona: Total length, 556 millimeters (630-465); tail vertebrae, 71 (90-50); ear from notch, 139 (163-127); hind foot, 132 (145-112). The average weight of 47 adult specimens of both sexes was 5.5 pounds $(7.5-4.4)$.

Averages of 20 adult females: Total length, $572(610-540)$; tail vertebrae. 72 (90-50); ear from notch, 136 (145-127); hind foot, 131 (145-112). The average weight of 24 adult females was 5.9 pounds $(7.5-4.4)$. Ten non-pregnant females were found to average 5.8 pounds (7.3-4.4) in weight, or almost as much as the whole lot of females.

Averages of 12 aduit males: Total length, 559 (630-465); tail vertebrae, 70 (90-55) ; ear from notch, 143 (163-136); hind foot, 133 (145123). The average weight of 23 adult males was 5.1 pounds (6.1-4.4).

Here again, sex differences in size are insignificant.

Dixon (1926), found marked differences of both length and weight between the sexes of $L . \varepsilon$. richardsonit in Kings County, California.

\section{STRUCTURAL ADAPTATIONS IN THE JACK RABBITS}

The jack rabbits are specialized in numerous and important ways. While we cannot at present go into this phase of inquiry, we believe an intensive study of their adaptations to environment would be of interest as well as importance. To get the most out of such an investigation close attention should be given to behavior as well as structure of the animals. There is nothing commonplace about the jack rabits. They attract almost instant notice from passersby. Their speed of running. associated with lanky build, long legs, and appropriate musculature, is perhaps the most conspicuous of their characteristics; but their sensitive hearing, associated with their phenomenally long ears, is only slightly less so. Among other adaptations deserving mention are their independence of a supply of free water and their success in hiding their young.

There is hardly a feature in the structure or behavior of the rabbit which would not well repay critical stucly. As a living machine, adapted to life in an arid environment, the jack rabbit is an outstanding sticcess.

\section{DISTRIBUTION AND HABITAT LEPUS ALLENI}

Lepus alleni belongs to the subgenus Macrotolagus, and is one of the so-called Lepus callotis group of white-sided jack rabbits, a group principally Mexican in distribution. Three species and two subspecies are 


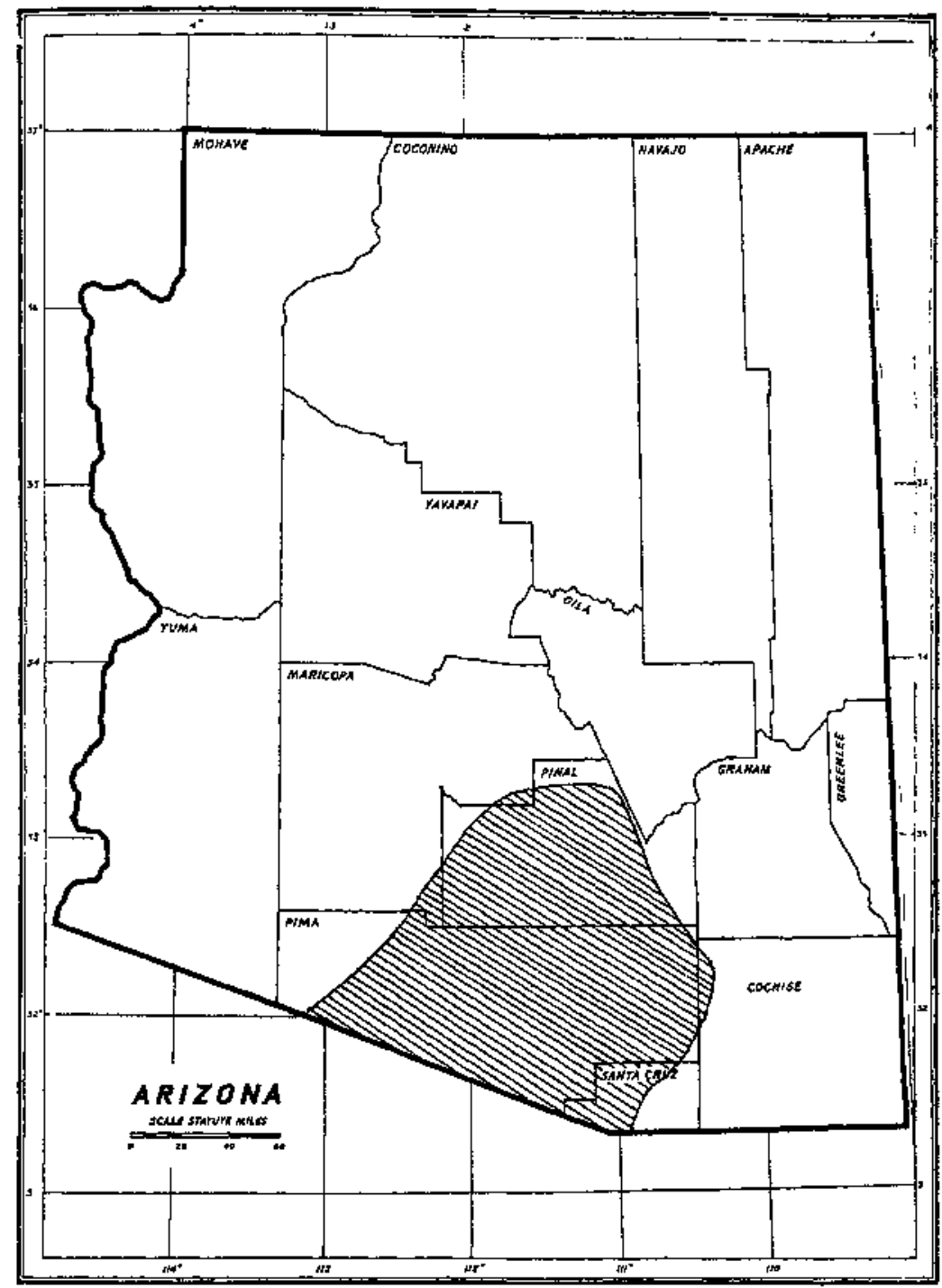

Fig. 1.-Range, in Arizona. of Lepus alleni (shaded area) compared with that of Lepus coliformicus $\mathrm{ssp}$, which occurs all over the State.

exclusively confined to that country, and but two forms, L. allenti and L. gaillardi, get into the United States. L. gaillardi barely crosses the line into extreme southwestern New Mexico, while the antelope jack rabbit (L. alleni) is found over a considerable portion of southern Arizona (Figure 1). 
Yothies, on a trip from Tucson to Port Libertad, Sonora, Mexico, observed Lepus alloni at intervals all the way, this extending to the westward the range of the species as mapped by Nelson (1909, p. 116).

In Arizona $L$. alleni is found north to Queen Creek and to a point half way between Sacaton and Chandler (Maricopa County), east to Cascahel, Pantano, and Empire Ranch (Pima County,* and west to Quijotoa Yalley, Quitobaquita (Pima County), and Casa Grande (Pinal County). Southward this jack rabbit is found to a little beyond Guaymas, in southern Sonora, Mexico.

The species is exclusively Lower Sonoran. It is found from sea level to an average altitude of about 4,000 feet. We have one record. V. R. Ranch, near Rosemont, Pima County, Arizona, 5,000 feet.

The antelope jack rabbit occurs in a variety of situations in Arizona, seeming to prefer grassy slopes at moderate elevations. The animals seem to like the bahadas or mesas above the giant cactus belt, where grasses, mesquites, and catclaws abourd. They occur also, somewhat scattered, on the creosote desert, and even, at times, in the heavy mesquite growth along the valley bottoms. On the grassy bahadas at altitudes of perhaps 3,500 feet, the antelope jack rabhits are usually several times as numerous as the I.epris californicus type; but in the mesquites along the valley bottoms, and on the barten creosote bush desert, the L. californicus type is ustually more numerous. Lepus alleni is rarely observed in broken or hilly cotuntry.

We are unable to determine the factors limiting the distribution of the antelope jack rabbit. Altitudinally and zonally temperature may possibly control. In general, the grass is both more dense and of greater volume above the point at which $L$. alleni stons. There is often a better supply of otber food, also, as mesquite and other herbage. Habitats apparently suitable extend to the north, in the direction of Phoenix and Wickenburg, well beyond the last antelope jack rabbit. There are no appreciable physical or climatic barriers except to the westward. In the vicinity of Gunsight, Pima County, the soil and vegetation change somewhat, the soil becoming softer and more sandy. Some mammals occur in the sandy soil to the west which are not found in the harder soil to the east (Vorhies and Taylor, 1922, p. 9). The vegetational change as a barrier is difficult to define, but to the westward through this region there is Iess precipitation, and succulents, on which the jack rabbits would have to depend more and more for water, become less and less abundant. The limit of distribution to the westward is less puzzling than in other directions. In the vicinity of and for some distance to the east of Pantano the grass cover becomes much improved, and there the antelope jack rabbit drops out.

\footnotetext{
* Recentiy observed by the authors east to near Fort Huachuca, Cochise County.
} 
The occurrence of antelope jack rabbits on the Santa Rita Range is very spotty. They frequently congregate in places where mesquite is thick and grass correspondingly reduced. The animals are more abtundant than elsewhere over a certain tract, several square miles in extent, centrally located in the mesa type in Pasture 2 of the Range. The grass on this area is scattered and the noxious burroweed, (Isoconta coronopifolia)* is abundant. Mesquite and other shrubs are present in moderate abundance. There is a "lick" in this area, where rabbits evidently go to eat soil. The poor character of the grass on certain areas of rabbit concentration may be due in part to soil conditions and overgrazing by livestock, and in part to grazing by the rabbits themselves. it is entirely possible that overgrazing by livestock has reduced the grass and brought on a crop of weeds and that the rabbits have been attracted by the more open country and perhaps by the more palatable varieties of these weeds.

At times one finds the jack rabbits abundant on the mesas, at others in the shallow washes, which ordinarily possess a greater variety of vegetation than the mesas. The jack rabbits may therefore at times find better food and shelter in the washes, and there, during the heat of the day or when a wind is blowing, they tend to congregate.

\section{THE LEPUS CALIFORNICUS GROUP}

The Lepus californicus group, also of the subgenus Macrotolagus, is made up of the so-called gray-sided jack rabbits. To it belong $L$. californiczus with 14 subspecies and $I_{\text {. }}$ insularis of Espiritu Santo Island, Lower California. The members of the $r_{\text {. }}$ californicus group constitute the typical and well-known jack rabbits of the western United States (Nelson, 1909, p. 127). They range from South Dakota and eastern Washington south to the Valley of Mexico, and from the plains of Kansas and Texas west to the Pacific Coast. Altitudinally the group occurs from sea level to 8,000 feet or more in the Valley of Mexico and the monntains and plateaus of our own arid interior. The range of the species embraces every life zone from the upper border of Arid Tropical through the I,ower and Upper Sonoran well into the Transition Zone. In its flexibility of geographical, ecological, altitudinal, and zonal requirements, the $L$. californirus group of jack rabbits stands in vivid contrast to the group of white-sided species.

Information gathered within the ranges of the several subspecies of Lepus californicus in the Southwest has been entered under the species rather than the subspecies. Data available are not stufficient to war-

* Dayton (Misc. Pub. 101, U. S. Dept. Agric., 1931, p. 157) uses Aplopappus fruticosus for the burroweed. 
rant an attempt to treat the subspecies separately, although this is desirable and ultimately may be mperative. The subspecies concerned are:

Lcpts californicus deserticola, type locality west edge Colorado Desert, California. Range: Southeastern California, the greater part of Nevada, western [tah, western Arizona, and northwestern Sonora.

Lefus calfornicus eremicus, type locality Fairbank. Cochise Connty, Arizona. Range: Sorthern and sottheastern Arizona.

Lepus californicus texiants, type locality probably Western Texas. Range: Northeastern Arizona, southwestern Colorado, New Mexico except northeastern corner, western Texas, and a considerable area in northern Mexico.

I.epus californicus melanotis, type locality Oklahoma, near Independence, Kansas. Range: Northeastern New Mexico, northern Texas, eastern Colorado, most of Nebraska and Kansas, and western Oklahona.

Lepus californicus merriani, type locality Fort Clark, Kinney County, Texas. Range: Southern Texas and northeastern Mexico.

\section{GENERAL, HABITS}

\section{GREGARIOUSNESS}

Whether or not jack rabbits may properly be spoken of as gregarious we frequently see groups of from two to six individuals, especially of antelope jack rabbits, in suitable places and at all times of the year. In many cases these groups are undoubtedly associated for breeding purposes, for one or more males may be found in the vicinity of a female. In other instances, groups are of a single sex.

As an example of concentration, Foster told us of seeing on one occasion 17, and again 25, antelope jack rabbits in one bunch near Batamote Ranch, Sierrita Mountains, southern Arizona.

On February 24, 1928, antelope jack rabbits were abundant on the slopes of certain washes on the Santa Rita Range. Between 5 and 6:30 p. m. $4,6,10,12$, and even 20 of these rabbits were observed, scattered well out over the landscape, and finally, by carefully scanning the area panoramically from one point, 32 were seen. These were not bunched, but weil scattered out. Nearly all were feeding or watching; very few were resting.

Between 3:30 and 4:00 p. m., February 20, 1925, few antelope jack rabbits were found on the mesas of the Santa Rita Range. A count made over a 2-mile course disclosectmonly seven individuals, but in a 
certain large wash they were abundant. Apparently the rabbits had resorted to the wash to escape the effects of a strong wind. Groups of half a dozen or more rabbits were commonly observed. Sixteen ran out from the wash onto the mesa at about the same time. In a few minutes 50 were counted in the wash, and in half an hour about 100 were seen. Observers in a different part of the wash reported similar large numbers.

For years it has been noticed that in another tract in a protected wash on the Santa Rita Range, the antelope jack rabbit seems usually to be present in fair numbers, even when scarce elsewhere. A particularly notable concentration was evident in January and February, 1931, when between 50 and 100 individuals were observed on 10 acres. The animals were abundant in this area through January, February, and March, except once in March when they were nearly all absent; but they appeared again in somewhat reduced strength the following week. During this period counts of rabbits were being conducted all over the Range, and no other concentration of so large a group was discovered. By April 21 this aggregation had broken up. Such concentration in this area was conspictrously absent in the corresponding montls of 1932.

\section{DAIIY MOVEMENTS}

Where food and sheiter are available in one place, no major daily movement of the jack rabbits occurs. Thus during January, February, and March, 1929, Aldous found the animals remaining in the mesquite and blackbrush areas of the Jornada Range, where they enjoyed excellent protection, and where, at the same time, food was available. Probably little movement occurs anywhere when grasses and brush are found together in fair mixture. The rabbits obviously move out from shelter into the small open spaces in late afternoon, say from 4 or 5 o'clock on, and can be seen there in the early morning hours before they retreat to their near-by forms for the day.

But when "food areas" and "shelter areas" are separated by some distance, a morning and evening migration may be readily observed. It is frequently the case that brushy areas suitable for shelter have scant grass or other food, while tracts where food is abundant are short on shelter. The amount of jack rabbit movement varies in accordance with the distance between these areas. It may mean merely travel from brushy washes to near-by grassy mesas, but often succulent grasses and herbs are found on valley floors at some distance from brushy refuge. Daily movements of 1 or 2 miles each way must be fairly common. In dry seasons migrations of 10 miles round trip from desert to alfaifa 
tields are known. At such arid periods jack rabbits characteristically invade the outskirts of desert cities and towns, moving onto green lawns in tate evening and doing some clipping of roses, hedges, and similar ornamentals. The stuburban hoitseholder, rising at dawn, may find a number of big hares industriously clipping his grass. About sunrise they begin to move ofi, particularly if disturbed by passing cars. Similarly from other feeding grounds there may be seen in eariy morning a rather leisurely jack rabbit migration back to the brushy areas. Nursing females regularly move to their young at night, and away from them in the daytime (see p. 505).

Times of leaving and seeking shelter vary not only with individuais but with the kind of weather and time of year. In hot, sunny, summer weather jack rabbits look for the shade at least by 8 or 9 o'clock in the morning. If furced to sit out in the sun at midday, as when being closely followed for observation or photographing, they are noticeably uncomfortable. This discomfort in the midday sun may be noted as early as late March, and is not surprising, since the soil surface on the Santa Rita Range attains maximum temperatures of $120^{\circ} \mathbf{F}$. to $130^{\circ} \mathrm{F}$. at this season, rising in June to maxima of $150^{\circ} \mathrm{F}$. to $160^{\circ} \mathrm{F}$. In January or February, on the other hand, many jack rabbits may be seen basking and dozing in the warm sunshine, even at midday. The soil surface maxima on the warmer days of January and February, 1931, tan between $80^{\circ} \mathrm{F}$. and $90^{\circ} \mathrm{F}$. with two days for short periods at $93^{\circ} \mathrm{F}$. and $95^{\circ} \mathrm{F}$. On cloudy summer days jack rabbits are likely to be seen in the open at any hour of the fay, but on such days in winter, particularly if a chill wind be blowing, they hunch down close in the best sheltered forms accessible and are difficult to see.

\section{SEASONAL MIGRATIONS}

We have not observed any distinct or regularly recurrent seasonal migration in either species of jack rabbit in southern Arizona, a fact possibly correlated with the absence of a severe winter climate.

Gorsuch, in residence for some months near the old Parker Ranch at the upper border of the Range, noted few or none of either species early in May, 1931. From that time to the last of June, when the grass had come up well, the numbers of jack rabbits appreciably increased. It seems obvious that jack rabbits must frequently move in response to growth of succulent vegetation.

In autumn, 1927, Nichol noticed that californicus was abundant on 
the foothills northeast of Vail. A check-up in December showed the same area practically free of jack rabbits. Snow had fallen recently in the hills, and a sharp cold spell had followed, and we can only surmise that the rabbits had moved to a lower, somewhat warmer region.

Hollister, at Mojave, California, did not see a single jack rabbit from January 9 to February 5, 1905. He was told they were plentiful in sunmer and fall but always scarce in winter. That they had some time been abundant he verified by "plenty of old sign."

Bailey found the distribution of californicus in New Mexico in August, 1908, more or less dependent upon the presence of green food. The rabbits left the dry and barren valleys or slopes that the rains had missed, and gathered in numbers in other sections where green grass and succulent plants were available. These seemed to be local migrations or wanderings, comparable to the drifting of stock to the best range.

By all odds, the most definite and striking record we have seen of jack rabbit migration comes from Oregon, where Gabrielson in Malheur County, December 21, 1921, reported observing a very considerable movement of the animals. While he was traveling in a blinding snow storm at a low temperature from the high country to the north of Ontario 6 miles towards Ontario, thousands of rabbits were seen, all traveling down hill. They were all moving into the face of this storm and all going in the same direction. Neither rabrielson nor those with whom he talked had ever seen anything like it.

Jack rabbits make conspicuous trails. These may indicate local movements, perhaps nocturnal, of which we know little or nothing. On a certain ridge of the Range there is an unusually well-marked trail extending for some distance along the crest. On approach of an observer several to many antelope jack rabbits, when frightened at a distance, may be seen coursing along this trail, always going down the slope away from the mountains. Thirteen individuals have been seen thus in a single file. The tendency on the part of the antelope jack rabbits on the higher parts of the Range to move down grade when alarmed is characteristic. The animals leave the neighborhood only temporarily, however, for observations on succeeding days show undiminished numbers present.

\section{EXTENT OF HOME RANGE}

Information on the home ratnge of rabbits is disappointingly meager. It is somewhat surprising to be forced to realize that so wild and free a creature as the jack rabbit may have a definite home range at all. As 
one ordmaril sees the animal, running across country at the rate of 25 to 40 miles an hour, he gets such an impression of limitless liberty that it is difficult to feel that the jack rabbit is in any way restricted.

On the other hand, the obvious concentration day after day of rabbits in particular places, often of relatively small size, indicates a degree of localization, and there is no doubt at all that some individuals at least return even to partictlar forms (see p 504). An observer once followed an individual of Lefus alleni at a respectful distance, so as not to alarm it, for an hour and a half The animal remarned in an area perhaps 500 feet on the side. It seemed very definitely to prefer to stay in the same general locality.

Seton (1929, pp. $704-705)$ found the home range of the snowshoe rabbit (I epus americanis phaeonotus) to be very small. He believed that in thick woods the home range was not over 20 or 30 acres, in more open woods perhaps twice that. One of the animals, under Seton's direct observation, spent all summer within a radius of 100 yards. It could not even be driven from this limited area Grange (1932, p. 5) also gives evidence for his belief that the snowshoe hare has a restricted home range. In one case this was estimated at 10 acres, and several similar instances were noted

From long observation of jack rabbits on the Santa Rita Range, however, we have formed the opinion that their home range in that locality may be several miles in diameter It is not improbable that californicus, ordinarily an animal of the open plains, has an extensive home range, and alleni, of large size and a dweller in arid lands, perhaps an even more extensive one.

\section{ATTITUDES AND MOVEMENTS}

The attitudes and movements of the antelope jack rabbit, whether resting, feeding, playing, fighting, or running from an enemy, are decidedly more spectacular than those of the Arizona. At times, the animal sits orl its haunches in the form, fore feet down on the ground in front of it. From this position it can make a sudden leap and a very very quick get-away. When more relaxed, the rabbit crouches low in its form (Plate 2, A) folding its fore legs back under the front part of the body, the backs of the fore feet down, the palms up. In this case, the animal must needs rise to the paims-down position before starting off, and a slight alarm brings this response.

The ears, as the jack rabbit rests or dozes, are laid along the back in a relaxed position. At slight alarm, the atimal rises to a leaping posture and brings up the ears to a position of attention. If it decides to 


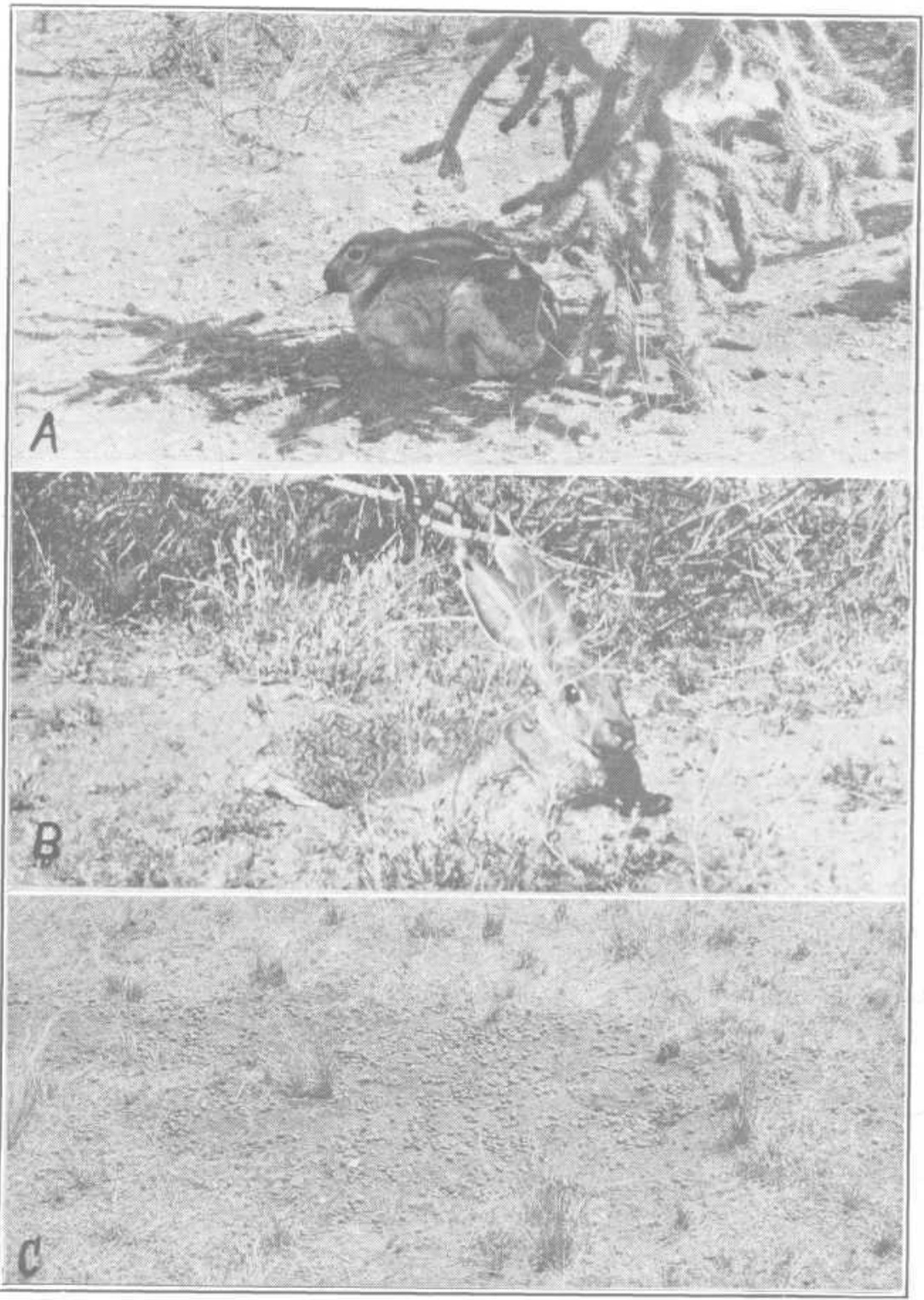

Plate 2.-On the Santa Rita Range: A, Even when in plain view, the antelope jack rabbit crouched low in its form with ears down is often difficult to see; B. An antelope jack rabbit much relaxed. Note how admirably the animal fits into its environment; $\mathrm{C}, \mathrm{A}$ jack rabbit defecatorium. The animals have evidently resorted to this place probably for rolling and resting as well as defecating. 
trust to conceajment rather than flight, it hunches down lower than ever in the form, pressing the ears tightly against the back. We have frequently seen rabhits in the distance, ears erect. As we approached the ears were slowly lowered, like a semaphore block signal, the rabbit "freezing" and becoming very inconspicuous. Lepus alleni frequently crouches or rests at ease flat on its form with fore legs extended, and sometimes in the open stretches out lazily, flat on one side, to bask in the sun like a cat (Plate 2, B). Such an off-guard posture in so timid an animal is surprising. Occasionally an antelope jack rabbit may be closely followed for 2 or 3 rou $s$ at a time, becoming almost indifferent to the presence of the observer, and carrying on its activities in an apparently normal manner. It has been possible to observe one dozing in its form and in the (winter) sun; gathesing itself in readiness for a sudden start; taking a long, lazy stretch when made to leave its form unwillingly, but not greatly alarmed; feeding; washing its face; extracting thorns from front or hind feet; rolling in dust or sand (Plate 2, C); and in all stages of flashing the white rump

Lepus californicus in southern Arizona is very much the more timid of the two species, and we have not been able to observe it so closely.

\section{THE RUMP-FLASH}

Of all the remarkable features possessed by the antelope jack rabbit, the rump-flash is one of the most spectacular. When this rabbit runs away from an observer, a conspicuous white area shows up on the rump, appearing to shift each time the animal turns, the white being kept toward the observer, partly by the manner of holding the skin and partiy by the zigzag course taken by the running rabbit. This is the rump-flash from which the white-sided jack rabbits take their name, and which is responsible for the term "antelope" as applied to $L$. alleni.

The white on the rump is flashed by a set of skin muscles that pull the skin of the hind quarters over the back and up on one side at the same time everting the hairs, thus exposing a surprisingly large white area on the left or right rear as the case may be. The hindward part of the median dark band of the back is thus thrown in a curve to right (or left), the diagonal position of the posterior end of this curve being continued by the black of the tail which is held down and thrown diagonally to the left (or right). The movement of the skin (which is much looser than in californicus) and hair can be readily simulated in a freshly killed animal by stroking the skin of the flank and rump up and over. When startled, an antelope jack rabbit ordinarily flashes the white and 
is off so quickly that the details are not readily observed. Occasional individuals which can be followed closely will move about at their feeding or hop slowly away from an intruder without flashing the white, or will shift the skin partially or slowly and let it return to resting position without running away. The psychology of this movement seems fairly evident. Whatever else it is the rump-flash is clearly a fear reaction. The jack rabbit that is startled ustally flashes the signal and starts to run the same instant, and continues the flashing so long as it is sufficiently frightened to run. Individuals hopping about to feed, or running but not alarmed, as in play or chasing each other, do not show the white. Those observed at close range will sometimes flash if suddenly startled even though not sufficiently frightened to run away. A jack rabbit may start from its form with white showing, make one or two leaps and stop. While it remains poised for flight the white shows; if it relaxes its nervous poise and settles back to a sitting position, the dark mantle is lowered and the white disappears. With a reasonably tame individual one may almost cause the flashing or prevent it at will. The animal in flight never runs straight away, but follows a zigzag course ustually keeping the white of the rump toward the pursuer.

The use of the rump-flash, if it has a use, is decidedly uncertain. By some of those not familiar with it the rump flash is generally believed to be a directive signal by the rabbit to its fellows: "This way!" perhaps also a warning to predators that "This is one of the fastest of the jack rabbits - no use to follow!" Perhaps the rump-flash serves to inform other rabbits of approaching danger. The flash may help to confuse a pursuing enemy. When a quick change is made from the brilliant white rump to the darker "normal" coloration a pronounced obliterative effect is observed.

But the problem is confusing. One wonders why the rump-flash as a directive feature would not serve to attract the attention of predatory enemies equally as well as jack rabbits; and on the other side, why the obliterative effect would not tend to conceal the rabbit from its own kind as well as from predatory enemies.

\section{RUNNING, JUMPING, AND SWIMMING}

The running movements of Lepus alleni and Lepus californicus are so different that one familiar with both species can usually distinguish them at a distance, particularly when in full flight. Alleni botnds boldly away, often into the open, making a longer, higher, "observation" leap about every fourth to fifth jump. The leisurely moving, unfrightened individual which is not "flashing" does not make these observation leaps. 
Lepus californicus, while it may leap over snail bushes or similar obstables, is more prone to "sneak" away without making itself conspicuous by long leaps, and even when frightened pursues a flatter course, not bounding so high from the grontind in its observation leaps.

Speedometer tests show that probabiy both species of jack rabbits readily attain speeds of 30 to 35 miles an hour. Lepus alleni, at least, is capable of higher speed on rare occasions. One of these big jack rabbits was found inside our 2-acre rodent-proof exclosure, which is fenced with hardware cloth 3 feet high. This rabbit was being chased to learn whether it could or would jump over the fence. It finally became much excited and headed directly for the fence at high speed, giving an impression of being stretched out low and parallel to the ground like a greyhound. This individual certainly ran faster than those measured at 30 to 35 miles per hour. It evidently did not see the fence, made no effort to leap over it, struck the hardware cloth squarely and was thrown back 12 or 15 feet with a broken neck. Efforts to induce similar bursts of speed on the part of rabbits in the open have always failed. We have, however, seen one of these animals clear a fence $5 \mathrm{I} / 2$ feet high with an easy bound. Ordinarily, however, netting $2 \mathrm{y} / 2$ feet high suffices to exclude jack rabbits.

Naturally, jack rabbits in arid regions have little necessity and few opportunities to swim. On one occasion an Arizona jack was observed to cross voluntarily a shallow stream, where two leaps in the water were necessary. Another was seen to land accidentally in shallow water obscured by a surface layer of duckweed. This individual, though frightened, leaped back to shore rather than swim across the narrow arm of still water for a direct get-away.

\section{SENSES}

Of the five senses, only three, sight, hearing, and smell can be dis. cussed, and these only in a fragmentary way. Nothing can be said of the sense of touch save that the vibrissae on the nose are long and sensitive, and may be assumed to be useful tactile organs. The sense of taste must aid in the selection of the rabbit's food from a bewildering array of available plant life, but even here, the sense of smell plays an undetermined and probably important part.

With such enormous ears, one would assume the jack rabbit's hearing to be keen; and observations in the field bear out the assumption. Jack rabbits at times leave their forms and take to flight at such distances in advance of the observer, and under such circumstances, that the onily 
tenable hypothesis is that they have heard his approach. Intervening brush or other objects may cut off the view, and a breeze coming toward the observer may eliminate odor, yet the animal senses his coming and escapes. The movements of the ears are precisely those which we have learned to associate with their use in animals of keen hearing.

The nose, like that of the domestic rabbit, is continually in quivering motion, giving an impression of sensitiveness which is borne out by field studies. While we are accustomed to associate the keenest olfactory sense with carnivores, it does not necessarily follow that this sense is any less keen in the herbivores for those things which are important in their lives. While the jack rabbit does not need to trail or stalk an absent animal to secure its food, it evidently does make its first and often apparently its sole test of a plant through the sense of smell. If the odor is satisfactory it tastes, if not, it refuses to eat. Furthermore, the presence of anal glands indicates the possibility that the jack rabbit may recognize or trail other individuals of its own species.

The eyes of the jack rabbit are large and luminous, (shining pink in a white flashlight in the dark), but apparently of little use for distinguishing still objects or details. Movements quickly catch the attention of the animal which, crouching in its form, watches the approach and particularly the activities of a suspected enemy. While man is more fearful of the approach of an object indistinctiy seen, the jack rabbit (particularly Lepus alleni) can often be closely approached from the obviously incomplete shelter of a bush or cactus, while a step in the open causes immediate fight. Whether this is due to more discriminating vision in man or to differences of imagination one cannot say. Movements are, on the whole, less alarming to the jack rabbit than sounds. A young caged Lepus californicus did not seem to find things so much by sight as by smell. When its water can was placed before it the rabbit did not seem to see it (recognize it by sight) but approached it in a gingerly manner, ears forward, apparently trying to hear or smell it. When the rabbit approached the water closely there was no further difficulty and the animal plunged its nose into the water and drank like a horse. The same gingerly approach was observed when fresh alfalfa was put in the rabbit's cage.

\section{BREEDING HABITS}

Information on breeding habits in Arizona has been secured almost wholly by examination of specimens killed in the regular course of our study, or during rabbit drives. 


\section{LIFE SPAN}

The length of life of a jack rabbit is unknown. No data are available for estimating it by comparison, since the life span even of the domestic rabbit is not definitely known. Klugh (1926) says the snowshoe rabbit is "believed to live for eight or nine years." Probably few individuals live out the normal life span to perish of old age, as enemies or disease account for the vast majority.

The age at which breeding begins can be arrived at only indirectly. In July and August individuals appear which seem to be full grown, but which when killed and weighed are found to be below average weight, to have a juvenile appearing pelage, and to show no indication of breeding. or, if females, of ever having bred. Such virgin females, assumed to be very early young of the year, are not uncommon in late summer and autumn when practically all other females are in some stage of breeding. Occasionally such individuals, probably young of the previous summer or autumn, are found in the spring months. One specimen (Lepus californicus), reared in captivity, was kept until past 11 months of age and only then assumed an appearance of full maturity. It seems doubtful, therefore, whether breeding occurs under one year of age. It is possible that an individual born in January may breed the following August, but since it would be scarcely 7 months old this does not seem probable. All wild jack rabbits born in a given calendar year may well breed sometime during the next year. Such an age of first breeding would be closely comparable to the findings of Hammond $(1925$, p. 25$)$ in the domestic rabbit.

\section{SEX RATIO}

We have recorded the sex of 482 specimens of Lepus alleni. Of these 253 were females and 229 males, a ratio of 52.5 percent females to 47.5 percent males.

For Lepus californicus our records show the sex of 237 specimens: 123 females, and 114 males, or a ratio of 51.5 percent to 48.5 percent.

These figures show no significant preponderance of one sex, and even such slight differences as appear might well be wiped out if our records were complete. We are not certain that every male specimen was recorded; most likely not. Sometimes when in the field primarily for breeding records, and where time or facilities were lacking for measuring, weighing, and recording ail the material, some male specimens may have been disregarded. Occasionally data were hurriedily taken from chance specimens killed on hunting trips or field work in other lines. On stich occasions we were more likely to record fernales than males. 


\section{BREEDING SEASON AND RATE}

The breeding season of the jack rabbits of the southern Arizona region is one of the longest known. Pregnant females of both species have been taken during 10 months of the year (December to September). Females suckling young have been taken in one additional month (October). This leaves but one month (November) out of the entire year when all indications of breeding are absent. Obviously a record by months is required, and Table 1 presents the data for Lepus alleni.

TABLE 1-LEPUS ALLENI, BREEDING* FEMALES, BY MONTHS.

\begin{tabular}{|c|c|c|c|c|c|c|}
\hline Month & 完 & 品 & 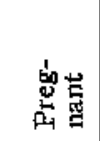 & $\begin{array}{l}\text { 驾 } \\
\text { 总 } \\
\text { 岕 }\end{array}$ & 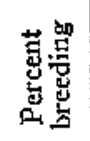 & Remarks \\
\hline January ......... & 10 & 4 & 2 & 6 & 60 & \\
\hline February --.-- & 17 & 1 & 15 & 16 & 94 & \\
\hline 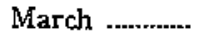 & 33 & 7 & 22 & 26 & 78 & \\
\hline April ................ & 32 & 8 & 19 & 24 & 75 & \\
\hline May …........... & 19 & 3 & 16 & 16 & 84 & \\
\hline June ............ & 38 & 0 & 29 & 38 & 100 & \\
\hline July & 10 & 0 & 9 & 10 & 100 & \multirow{3}{*}{$\begin{array}{l}\text { Young females, full } \\
\text { grown, non-breeding, } \\
\text { began to appear here, } \\
\text { but were omitted } \\
\text { from calculations } \\
\text { when recognized. }\end{array}$} \\
\hline August ........... & 16 & 0 & 9 & 16 & 100 & \\
\hline September .... & 17 & 4 & 2 & 13 & 76 & \\
\hline October ........ & 9 & 0 & 0 & 9 & 100 & $\begin{array}{l}\text { Suckling, but no } \\
\text { pregnancies. }\end{array}$ \\
\hline November .... & 19 & 19 & 0 & 0 & 0 & $\begin{array}{l}\text { All evidence of breed- } \\
\text { ing absent. }\end{array}$ \\
\hline December .... & 14 & 13 & 1 & 1 & 7 & $\begin{array}{l}1 \text { pregnancy, but on } \\
\text { last day of month }\end{array}$ \\
\hline Totals ........ & 234 & 59 & 124 & 173 & 74 & \\
\hline
\end{tabular}

* Breeding means any definite indication of breeding such as suckling, or congested uterus, and includes pregnancy. 
Table 2 gives the records on rate of increase, showing not only the number of young per litter, but the litter averages by months. The averages of litters by months have at least a suggestive significance, although the records for some months are few. The higher averages are in those months in which, usuaily, forage conditions are best, particularly as regards fresh green grass and weeds, which naturally appear at seasons of greater precipitation. Two rainy periods a year are characteristic of the soththern Arizona region, one in winter (December-March) and one in summer (July-September).

TABLE 2-LEPUS ALLENI, YOUNG PER LITTER BY MONTHS.

\begin{tabular}{|c|c|c|c|c|c|c|c|c|}
\hline Mionth & 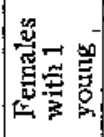 & 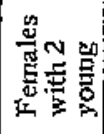 & 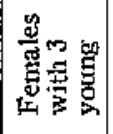 & 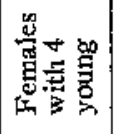 & 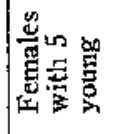 & 急兽 & 焉兽 & 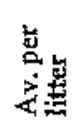 \\
\hline January ........ & 1 & 1 & & & & 2 & 3 & $1.50 *$ \\
\hline February .......... & 11 & 4 & & & & 15 & $1 y$ & 1.26 \\
\hline March & 5 & 10 & 4 & 3 & & 22 & 49 & 2.22 \\
\hline 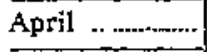 & 5 & 9 & 3 & 2 & & 19 & 40 & 2.10 \\
\hline May ............... & 10 & 5 & 1 & & & 16 & 23 & 1.43 \\
\hline June & 12 & 14 & 3 & & & 29 & 49 & 1.68 \\
\hline July & 1 & 3 & 1 & 2 & 2 & 9 & 28 & 3.11 \\
\hline August ......... & & 4 & 4 & 1 & & 9 & 24 & 2.66 \\
\hline September & 1 & & & 1 & & 2 & 5 & 2.50 \\
\hline \multicolumn{9}{|l|}{ October ......... } \\
\hline \multicolumn{9}{|l|}{ November ...... } \\
\hline December ....... & 1 & & & & & 1 & 1 & $1 *$ \\
\hline Totais ........... & 47 & 50 & 16 & 9 & 2 & 124 & 241 & 1.93 \\
\hline Percentages .. & 38 & 40 & 13 & 7 & 1.6 & & & \\
\hline
\end{tabular}

*Too few to be significant.

In Table 3 are shown the records of average precipitation for the region in which the major portion of the litter records were taken, compared with the litter averages by months. Most of the recorded alleni were taken in the great area embracing both Helvetia (near the Santa Rita Range) and Tucson. The means of the precipitation records for these two places, 35 miles apart with a difference of 1,600 feet in elevation, appear to be the logical figures to use. Following the winter rains, a lag in the appearance of green vegetation owing to low tempera- 
tures, might be expected, and actually occurs, a corresponding lag in the early spring breeding rate being noticeable. The lower average breeding rate in the arid fore-summer (May-June) occurs just where it might be expected, since most green winter annuals disappear at that season. There is scarcely any lag in the breeding rate following the midsummer rains, the summer vegetation springing up with amazing rapidity.

TABLE 3.-CORRELATION OF PRECIPITATION AND BREEDING RATE.

\begin{tabular}{|c|c|c|c|c|}
\hline \multicolumn{4}{|c|}{$\begin{array}{l}\text { Normal precipitation for Tucson (elevation } 2400 \text { feet) and } \\
\text { Helvetia (elevation } 4000 \mathrm{ft} \text { ) on Santa Rita } \\
\text { Experimental Range }\end{array}$} & \multirow{2}{*}{$\begin{array}{l}\text { Litter averages } \\
\text { by months } \\
\text { Lepus allemi }\end{array}$} \\
\hline \multirow[t]{2}{*}{ Month } & $\begin{array}{c}\text { Helvetia } \\
\text { 13-year av. }\end{array}$ & $\begin{array}{c}\text { Tucson } \\
\text { 63-year av. }\end{array}$ & Mean & \\
\hline & Inches & Inches & Inches & \\
\hline January .. & I.18 & .77 & .97 & 1.50 \\
\hline February & 1.64 & .86 & 1.25 & 1.26 \\
\hline March .... & 1.27 & .74 & 1.00 & 2.22 \\
\hline April & .62 & .34 & .48 & 2.10 \\
\hline May ........ & .40 & .14 & .27 & 1.43 \\
\hline June ........ & .50 & .23 & .36 & 1.68 \\
\hline 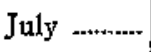 & 4.79 & 2.48 & 3.63 & 3.11 \\
\hline August ... & 3.22 & 2.33 & 2.77 & 2.66 \\
\hline September & 1.89 & 1.21 & 1.55 & 2.50 \\
\hline October .. & .52 & .53 & .52 & $\ldots .$. \\
\hline November & .93 & .75 & .84 & ......... \\
\hline Decernber & 1.47 & 1.13 & 1.30 & 1 \\
\hline
\end{tabular}

The total number of females taken, while considerable in the aggregate, is none too large for analysis when the two species are segregated; and if further subdivided according to the months of the year, is only sufficient to be strongly suggestive of certain breeding tendencies. The number of breeding females of Lepus californicus recorded is smaller, and hence less significant and reliabie, than of $L$. alleni. The trend shown, however, by the monthly tabulation (Table 4) of the former is essentially similar to that for the latter. 
TABLE 4,-LEPUS CALIFORNICUS. BREEDING FEMALES, BY MONTHS.

\begin{tabular}{|c|c|c|c|c|c|c|}
\hline Month & $\dot{0}$ & 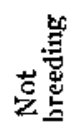 & 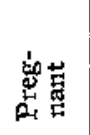 & 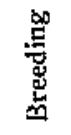 & 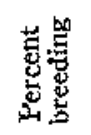 & Remarks \\
\hline January & 34 & 13 & 16 & 21 & 60 & \\
\hline February & 7 & 0 & 6 & 7 & 100 & \\
\hline March & 27 & 1 & 16 & 26 & 96 & \\
\hline Apri! & 21 & 4 & 13 & 17 & 81 & \\
\hline$\overline{\text { May }}$ & 12 & 3 & 5 & 9 & 75 & \\
\hline June & 14 & 0 & 12 & 14 & 100 & \\
\hline Juty & 2 & 0 & 0 & 2 & 100 & \\
\hline August & 2 & 0 & 1 & 2 & $\mathrm{I} 00$ & \\
\hline September & 1 & 0 & $I$ & 1 & 100 & \\
\hline $\begin{array}{l}\text { October } \\
\text { and } \\
\text { Novernber }\end{array}$ & 28 & 25 & 0 & 3 & 10 & $\begin{array}{l}\text { Jornada Range; no } \\
\text { pregnancies; three } \\
\text { suckling young. }\end{array}$ \\
\hline December & 4 & 1 & $2 *$ & 3 & 75 & $\begin{array}{l}\text { All taken between } \\
\text { December } 20 \text { and } 31 \text {. }\end{array}$ \\
\hline Totals & 152 & 47 & 72 & 105 & 68 & \\
\hline
\end{tabular}

* Recorded on December 24 and December 31.

For 70 females of Lepus califormicus we have recorded a total of 157 young, an average of 2.24 per litter. This exceeds the average for Lepus alleni (1.93 per litter), a species difference which has been in evidence from the beginning. The maximum litter recorded was six, (Table 5), one more than for L. alleni. The breeding rate of Lepus californicus is 16 percent higher than that of $L$. alleni if the number of litters per year be the same.

TABLE 5,-LEPUS CALIFORNICUS EREMICUS, YOUNG PER LITTER.

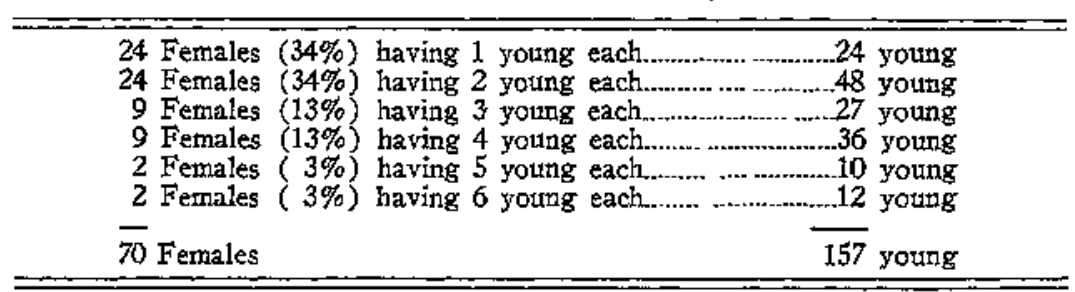

Supplementing these data, Aldous reports the examination of seven female L. californicus at Wilicox, Ariz., April 15-19, 1929, all pregnant. 
Five contained two embryos each, and two but one each, an average of 1.7 per litter. He also noted that there were no pregnancies in "several females" examined at the same locality January 25-28.

Aldous also contributed data on 32 female $L$. californicus examined between February 27 and April 11, 1929, in New Mexico (on the Jornada Range, and on a ranch east of the Organ Mountains), which show a lower breeding rate than our own records. Only one of the 32 was non-breeding. Thirty-one contained from one to three young each, but with a total of only 46 young, an average per litter of 1.48 .

Notwithstanding out rather accurate data on the young per litter and the length of the breeding season, we are at a loss to determine the number of young per female per year, for unfortunately, the length of the gestation period in jack rabbits is unknown. Gestation in the domestic rabbit requires 30 days, but the young are born naked, blind, and helpless. The eyes do not open until the tenth day, and the young are fully 3 weeks old before they compare in size and development with new-born jack rabbits. Therefore the gestation period of the latter must be longer. Six weeks would appear to us a conservative estimate of gestation in wild jack rabbits.*

Pregnancies frequently occur while young are being suckled, and in many cases the litter, even when it consists of more than one, is borne in one horn of the uterus. In fact, our records show 61 pregnancies in one horn to 20 in both, and two instances in which litters of four each were contained in one horn. Eliminating from the 61 those which could only be on one side (i.e., litters of one only) there remain 31. litters in one horn to 20 in both. Since the non-pregnant horn of the uterus remains in (or returns to) normal non-breeding condition, and since in domestic rabbits coitus is allowed at any time during pregnancy (Hammond, 1925 , p. 48 ), it would appear that superfoetationt might readily occur. Furthermore, the rabbit uterus is primitive, each horn opening separately into the vagina. Thus the closure due to pregnancy need not affect both and the unused horn might be open to fertilization throughout pregnancy. We have never found a case of superfoetation, however; in fact, no case is known among wild mammals in which coitus is permitted during pregnancy. It is extremely doubtful that super-

* Grange (1932, p. 12) has determined the gestation period of $L$. a. phoeonotus to be 36 days.

$\lceil$ Double pregnancy; a second pregnancy occurring before the first conceived young are delivered. 
foetation ever occurs even in the domestic rabbit, $x$ and it appears to be extremely unlikely that there is ever any overlapping of sticcessive litters in our wild species. The point is that at least a short period of time must elapse between the birth of one litter and the conception of another. Without accurate means of determination of the length of this period, we reason by analogy that it may be very short, since Hammond with the domestic rabbit has proved the occurrence of fertile coitus within 24 hours after parturition (op. cit., p. 46). Field observations confirm this reasoning. We have frequently noted one-sided pregnancies in individuals which were not only suckling, but in which the empty horn showed clearly that they had but recently had young. Some of these pregnancies must have occurred almost immediately after parturition. By no means all of the pregnant females which were suckling young had conceived the next litter so soon, however, and it would perhaps be conservative to assume an average of 2 weeks between parturition and succeeding conception during the active breeding season. In the domestic rabbit the percentage of fertile coitions in the first 4 days after parturition is much greater (nearly 100 percent) than in rabbits not recently pregnant (31 percent infertile, Hammond, op. cit., p. 38). Analogy applied here would indicate a high percentage of pregnancy in wild rabbits shortiy following parturition. Considering the difficulties of accurate interpretation of these conditions in the field, we believe it to be more conservative to allow the suggested 2 weeks between pregnancies. This, plus the estimated 6 weeks' gestation period, gives 2 months as an approximation of the time required per litter.

During 8 months of the year pregnancy seems to follow pregnancy rather regularly. At the rate of 2 months per litter there would be four litters anntually, which at an average of two young per litter would be eight offspring per female per year. This rate is far lower than for domestic rabbits and cottontails as well as considerably under the usual ideas of the general public for jack rabbits. We feel, however, that even eight per year may be too high, since unfavorable environmental factors, drouth particularly, through the food supply, doubtless affect the number of young and perhaps even the number of litters. Klugh (1926) believes that the varying hare, $L$. americanus, produces but one litter of three or four young per year. Grange (1932, p. 12) has records on

\footnotetext{
* Hammond has shown that ovulation in the non-pregnant rabbit follows, and is the result of, coitus, occurring 10 hours later (op. cit., p. 56). But he has also shown that in the pregnant rabbit, while the desire for coitus remains, the act is not followed by ovtlation even up to 24 hours, or even 2 hours, before parturition (op. cit., p. 51 ).
} 
six litters of this species, born in captivity; one of a single young; two of three each; three of four each. In one instance there were two litters in one season.

\section{SEX BEHAVIOR}

Very little information can be secured on sex relations in the field, first, because the sexes are indistinguishable except by inference from behavior; and, second, because most of these activities are carried on during hours of darkness. Frequently one animal may be seen closely following another in a manner strongly suggesting the following of a female by a male. On other occasions the following of one individual by another appears to be the pursuit of a male by a rival male; but between these more clear-cut instances may be seen many chases even less susceptible of clear interpretation. Our observations lead us to the view that both Lepus alleni and $L$. califomicus are completely promiscuous in their sex relations.

In observations of many hundreds of hares during all daylight hours we have seen but two completed copulations and two or three unsuccessful attempts, all of $L$. alleni. One of these coitions took place at $11: 25$ a.m. on a dark, misty day. The other took place in late evening just before sundown. The manner of copulation is almost identical with that of the domestic rabbit. In one case the female, immediately after completion of the act, chased the male several feet, uttering a peculiar growl or "grunt." In the other instance a chase and vigorous combat, accompanied by continuous growling, preceded coition.

\section{VOICE}

The jack rabbit is one of the most silent of mammals. When caught. however, or sometimes when wounded, it cries in distressing tones, and often quite continuously until released or dispatched. Rarely a peculiar growling or grunting vocal sound, a rapidiy uttered "chuck, chuck. chuck" is made from the throat. On only one occasion have we heard this from an undisturbed individual, and in but a few instances otherwise, as when fighting or chasing each other.

\section{FIGHTING}

Jack rabbits not infrequently stage what appear to be regular boxing matches. We long believed these to be fights between rival males, and probably in most cases they are. The contestants rear up on their hind feet - not merely on haunches - and cuff each other vigorously and with great rapidity for several seconds, making the fur fly. Usually 
these contests are fought out in silence. The fight often ends in pursuit of the ranquished by the victor. Rarely the combat ends in a draw.

1 description of a battle between two Lepus alleni may now be given. The jack rabbits squared off, opposite each other, reared on their hind feet, and, with su ift pawing motions, went at each other with their fore feet. After one encounter they dropped down, assumed a nonchalant attitude, and resuned feeding. The nonchalance, however, was only for effect. Each must have been trying to catch the other off guard. Suddenly they again flew to the attack. So absorbed were they that the observer was hardly noticed. After a short but very brisk encounter, they again dropped back to a position of rest. One pawed a nearby bush, apparently practicing for the next round! The third round proved to be final. The rabbits, now dead in earnest, launched themselves at each other. They seemed to use, not only their fore feet, but their powerful hind feet also. The whacking "sput, sput, sput" of paws striking on body were easily heard. Half a dozen tufts of fur were dislodged and floated to the ground. The contest became altogether too hot for one of them, and he made off rapidly, the other close behind. After pursuing the vanquished one some 75 or 100 yards, the victor stopped. Soon after the pursued rabbit was seen feeding. Each round lasted but a few seconds.

Many jack rabbits bear evidence of fights with other rabbits, encounters with enemies, or the thorns and sharp branches of their environment. The ears are frequently torn. One antelope jack rabbit, observed near Tucson, had suffered near-scalping. A square inch of skin was torn from the top of the head, the bone being exposed. The wound had dried up and the rabbit was apparently recovering. Another individual had suffered a compound fracture of the lower fore leg. The stub had aried up and was in use, the foot still dangling from it.

The skin on the side of a 6-pound antelope jack rabbit (Santa Rita Range) had been quite badly torn so that several square inches of raw flesh were exposed. The wound had partially dried up, but apparently the individual had small chance to survive.

In March, 1924, near Congress Junction, Arizona, Taylor and Mursgrave took a number of Lepus californicus females that had their ears torn as if they had been fighting. The ears of one were so seriously injured that the circulation was cut off and most of the pinnae dried up and lifeless, readily breaking off when handled. Musgrave reports that jack rabbits fight like bulldogs, bite with their teeth, spar with the fore feet and kick with the hind feet. Gorsuch, March, 1931, reported observation of a fierce biting fight between two $L$. alleni. 


\section{PHYSICAL CHARACTFRISTICS IN BREEDING SEASON}

No physical changes sufficiently well marked to be noticeable in the breeding period have been observed. Close observation is required even to distinguish females carrying full-term young, and only rarely, have we been able to do so. The mammae are so flatiy placed along the abdomen that they are not noticeable even when most active. The mammillae, on examination of specimens, are readily found on nursing females. In both species the nammae are six in number; one pair pectoral, and two pairs abdominal.

The testes in the males of both species are usually in the scrotum during the breeding period. These organs are indistinguishable in the living animal in the field, and only moderately conspicuous when the animal is killed. In midwinter the testes are ustrafly withdrawn within the body cavity, but the inguinal canal is always open and the actual position of the glands is therefore somewhat variable.

The rectal glands, lying in both sexes on either side of the antus, secrete a substance which hardens to a nearly dry yellow to orangecolored flaky material, with a strong musky odor, somewhat disagreeable at close quarters. The characteristic odor of the animal apparently originates in these glands. Each is a simple sack about $12 \mathrm{~mm}$. deep and with a wide external opening. They do not appear to be any more active in the breeding season than at other times. Their function is unknown. It is possible that by means of these glands the individual leaves a record in the form or wherever it pauses to sit for a time.

\section{FORMS, NESTS, AND YOUNG}

Considering the relative abundance of jack rabbits, their large size, and the fact that they live in comparatively open country and on top of the ground, sturprisingly little is definitely known concerning their nests or young. Adult jack rabbits or those of large size almost never take shelter in any kind of hole or burrow, even when hard pressed or wounded. We have never seen one do so. Ligon reports that a twothirds grown jack rabbit ( $L$. californicus, New Mexico), badly frightened, entered a large hole in a prairie dog town. Jack rabbits are said to take to available holes sometimes when pressed by hounds.

Nelson in Jalisco, Mexico, in 1892, recorded the taking of a partiygrown $L$, callotis from a burrow where it had taken refuge from a caracara. Nelson believed the circumstance indicated that the jack rabbit had been bors there. 


\section{FORMS}

Jack rabbits of both species habitually rest by day in somewhat sheltered sittmg places commonly known as "forms." This term doubtless was applied first to the places of concealment made by cottontails or hares backing into or tunder clumps of grass, weeds, or brush and producing a cavity in the vegetation (and partly in the soil) which fitted the shape and size of the concealed animals so well as to deserve the name "form." The jack rabbit is not ordinarily so well hidden as the cottontail. The spot in which it sits varies from moderately well concealed to so open that the name "form" becomes a misnomer, save as to that part of it which is impressed in the soil. Even the soil impression may be so shallow and inconspictous as scarcely to be recognized. We shall use form, however, for these places regardless of their quality as hiding places.

At its simplest the jack rabbit form is merely a sitting place beside a cactus or mesquite trunk on top of the ground where no digging or scratching effort has been done. and without any vegetative protection. Sitting in such a form the occupant is in full view from at least three sides, but is protected from the sight of aerial enemies and sheitered from the noonday sun. Often the form is dug out so as to be a slight depression or a somewhat deeper excavation As a rule the resulting depression quite nicely fits the haunches of the reposing animal, being deepest at the rear end and sloping out to ground level at the front. If beneath a cholla cactus the form is likely to be flanked by fallen cholla joints (Plate 3, A). With the same ground impression the form may be more or less within some concealing grass or low herbage, or may be protected by low hanging branches of mesquite or catclaw, or fianked by standing cactus. Good concealment and protection are afforded the occasional animal that chooses its form well within the desert hackberry (Celtis pallida). In such a situation the jack rabbit is shaded, well sheltered from attack from above as well as from all sides, and thoroughly protected all around. Most of the forms of L. alleni are found under mesquite, cactus, catclaw, or hackberry, although any plant of sufficient size to afford some overhead cover is tused on occasion. L. californicus uses any of the plants mentioned, but on account of its habitat, and its somewhat smaller size, makes more use of smaller shrubs such as burroweed (Isocoma coronopifolia), snakeweed (Gutierrezia sp.), rabbit brush (Chrysothamnus sp.), and grass clumps.

Forms (ground measurement) average from 3 to 6 inches wide, and from 11 to 18 inches in length. In exceptional cases they are longer or wider. One double form of californicus in the Williams, Arizona, 


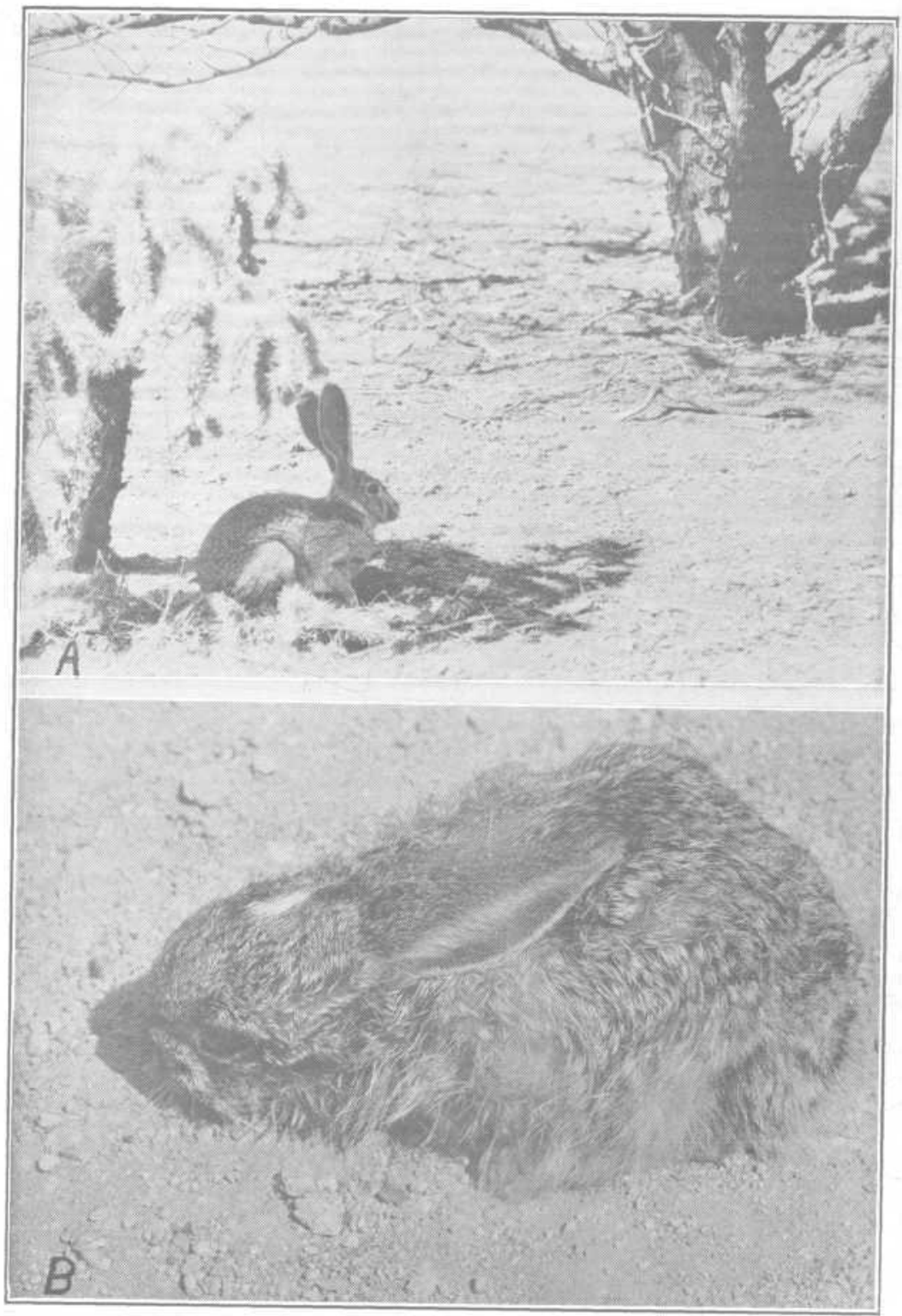

Plate 3.-A, Antelope jack rabbit in form beneath cholla cactus (Opuntia fulgida), Santa Rita Range; B, Young Colorado Desert jack rabbit from Congress Junction, Arizona, only two or three days old. Illustrates the immobility and generally protective attitude of the animal. 
area, made two arms of a "V", the rear ends together. Each arm measured 2 feet in length by 6 inches in width, and the deeper one reached a maximum depth of 3 inches. The depth of the forms generally varies from the slightest depression to a maximum of $3 \mathrm{I} / 2$ inches. Only in the deepest of these forms might the occupant find some temperature benefit in hot weather, and being usually shallow we must suppose they are scratched out mostly for the clearing of cactus, sticks, and stones, and a comfortably shaped seat. The forms are so variable that those of the two species are indistinguishable when not in use, although in general the forms of alleni are less well concealed than those of califormicus. The Arizona jack rabbit (califormicus) seldom or never sits about in the open during midday hours, while alleni does so not infrequently, especially on sunny winter days when it obviously enjoys baskung in the sun. At such times these jack rabbits sit out away from any semblance of a form. In February, 1931, on the Santa Rita Range, Vorhies saw an antelope jack stretched out on its belly in the sun, and on investigation found it was lying in a long, trough-like excavation the size of its body and an inch cleep, freshly dug for the purpose

Jack rabbits seem to be by nature too wandering to have a single form as a home and they probably do not have such a definite abode for long. There are many more forms than jack rabbits. We have, however, some evidence that the animals may remain for some time in the same locality. Vorhies photographed the same ear-marked individual on successive days at the same place, and what was believed to be a single individual was observed in the same form on at least three different occasions within a few days.

Klugh (1926) finds evidence that the individual varying hare remains in a very restricted area and uses a single form for a long time. It is probably not subject to such local variations in food supply as our arid region jack rabbits.

\section{NESTS}

Available data on nesting of jack rabbits are unsatisfactory. While we feel reasonably certain that Lepus callfornicus places its young in nests at birth, we are able only to surmise that $L$. alleni does so. We have spent hours of time and much effort, in the height of the breeding season, where the animals are common, searching for nests (or for young) of L. alleni, without success Two or three quite young jack rabbits have been found wandering about, but these discoveries seemed purely accidenta1. Years of experience in the field prove to our satisfaction that as one goes about his outdoor business he simply does not see the 
young that are less than half grown; and this, even the cattleman daily on the range corroborates. Forest Service officers and Biological Survey rodent control men also support these statements. Until they are nearly grown young jack rabbits are more wary than the adults, more strictly nocturnal and less prone to leave their forms.

Where then, are the young born and reared? L. californicus often places ats young in a prepared nest, more or less completely beneath the ground level, with some hair as a lining. This accords with observations of farmers who have plowed up nests in alfalfa fields. Gilchrist, in 1920, found eight nests in an alfalfa field in Salt River Valley, Arizona. These were on ridges ("borders") above the irrigation water, but were sunk into the ground, level with the surface. Each was thickly and warmly lined with fur and only a small opening was left at the top The nests were invisible except when plowed up, evidently having been closed and partly covered with earth when the mothers left them. Although no old rabbits were seen about the fields they were common out over the sides of the valley, and it must be that they visited the nests at night only, to suckle the young.* Musgrave reports having plowed up perhaps two dozen nests of a like character in eastern Oregon. The domestic rabbit not only well conceals its young in the nests but can seldom, if ever, be found with them by day. They are probably suckled exclusively at night. Our data on nests from this and other states indicate that $L$. californicus usually thus conceals and stckles its young. Sometimes, however, owing to adequate above-ground cover and hard soil. the nest is hardly more than an enlarged form beneath heavy grass clumps or brush. Thus, Taylor and Musgrave in March, 1924, west of Congress Junction, Arizona, found all gradations from surface forms to excavated globe-shaped nests The forms and nests varied from circular to elliptical, their dimensions varying from 15 to $22 \mathrm{~cm}$. long, and from 10 to $18 \mathrm{~cm}$. wide. Some of the forms were merely slight depressions in the surface, while the nests were excavated to depths of 3 to $11 \mathrm{~cm}$. All were well concealed in the grass.

In spite of otir failure to find nests of $L$. alleni, we have three definite records from competent observers. The first two of these, reported by Musgrave, indicate the same habit as found for califormicus. One, found in 1919 near Arivaca, Arizona, was located under a bunch of beargrass (Nolina). It was rounded out and covered with bits of beargrass, was excellently concealed, lined with fur from the mother, and contained two young. A second, found in 1920 near Magma, Arizona, was located under a mesquite bush in the edge of a clump of sacaton grass. It was

* They travel considerable distances to and from alfalfa iust for their own food. 
sunk about 8 inches into the ground, lined with fur, and contained one young rabbit. In February, 1925, Foster found the third recorded nest of allcni Its location was unique, being within a hollowed-out shell of a barrel cactus (Echnocactils sp.), 16 mches in drameter, which had been excavated to a depth of about 14 miches. Two young, large enotgh to hop around, were in the nest, well covered with fur from the mother.

Owing to the difficulty of locating nests, the suggestion has been made (Seton, 1929, p. 741) that our jack rabbits may scatter their young about at birth (Plate $3, \mathrm{~B}$ ) as the European hare is reported to do

Grange (1932, p. 7) working with the snowshoe hare ( $L$ a phaeonotus) has talked with many field mammalogists, hunters, trappers, and others, and has been unable in a single instance to find an authentic record of any definite nest In course of his studies six litters of snowshoe hares were born in captivity. In no case was a nest made by any of the parent hares.

The writers are impressed with the probability that with Lepus alleni the young are scattered out at or very soon after birth, and the young of L. californicus likewise, though perhaps the latter are left in the place of birth longer than the former.

\section{HABITS AND DEVELOPMENT OF YOUNG}

The discovery of young jack rabbits in the open being so difficult, such fragmentary data as we possess on their habits have been secured from individuals in captivity originally secured from slaughtered females. Full-term young of both species have been successfully taken from such females many times. Invariably, after being freed from the foetal membranes, when a few gasps have established normal respiration, the young struggle to a sitting posture and in less than five minutes make efforts to nurse. If placed next the mother they quickly find a nipple, but as the body rapidly cools the milk evidently does not flow well and the nipple is soon abandoned, though efforts to find a source of supply are actively continued

The young of both species are fully clothed with hair at birth, their eyes are open, and they can hop about actively. (Plate 4). Although in the general gray-mottled coloration they are strkingly similar, the young of Lepus californicus have the black ear tips of that species, while the ears of the young $L$. alleni are white-edged. The very young of the latter, however, do not show the characteristic white rump of the species. Almost invariably there is a small but distinct white spot in the center of the forehead of a new-born jack rabbit of either species, though in some cases this is hardly more than a few white hairs. 


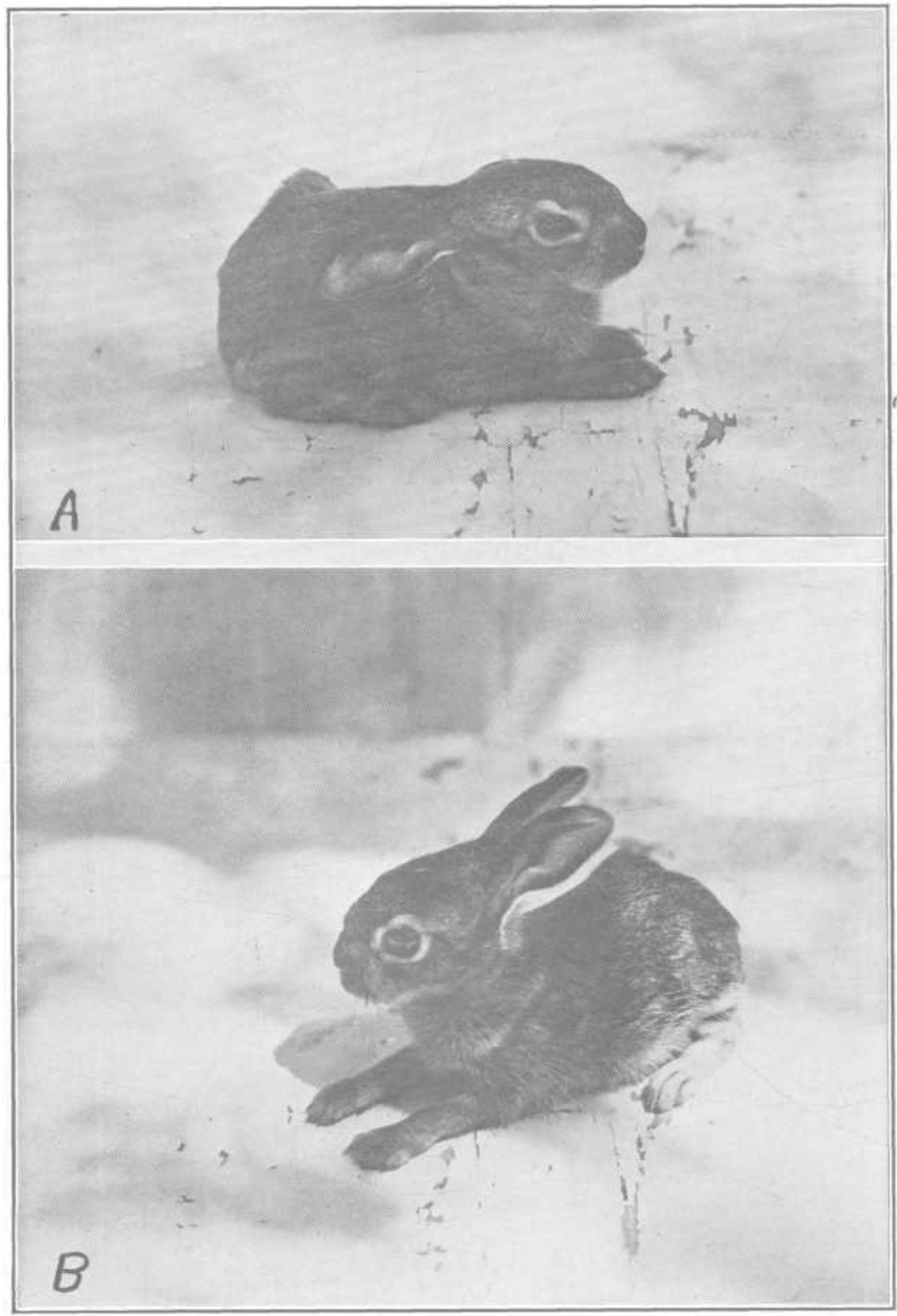

Plate 4,- Young antelope jack rabbit, shortly after delivery from mother by Caesarian operation, Santa Rita Range; A, In characteristic motionless daytime pose; B, Awake and active, as in twilight or hours of darkness. 
A tiny young Arizona jack rabbit was picked up by Gorsuch (August 13, 1930) under a Minosa in the grass on the Santa Rita Range. When touched on the nose the little fellow would rear up on its hind legs and strike or feint with its forepaws, assuming a very threatening appearance. We unceremoniously dumped the little animal into a box between some packages. He did not like this, and scrambled mightily until he got up on top where he could look around. He then settled down comfortably and made no further attempts to escape. We put him in a spring-floor rat trap for the night. He was exceedingly active throughout the hours of darkness. In the morning he was sitting, apparently uninjured, unconcerned, and comfortable, in a corner of the cage. Not having facilities for his care, we released him. He sat quiet and immovable, even when one of us stamped a foot right beside him!

Size at birth * is variable, even within a single litter, but the individual in a litter of one is probably as a rule larger than any one of a fitter of three or four. As it is difficult to secure accurate measurements of living young, our records are fragmentary.

One yotung Lepus alleni (litter of one) weighed 184 grams the next morning after being taken. Three individuals from one litter weighed respectively $108,103.5$, and 90 grams on the day taken. This gives an average for the four of 121.4 grams, with the largest more than twice as heavy as the smallest.

Measurements of two of the litter of three (after five days) were: Total length, each $150 \mathrm{~mm}$; tail vertebrae, 8 and $8.5 \mathrm{~mm}$; hind foot, 40 and $45 \mathrm{~mm}$; ear from notch, 37 and $40 \mathrm{~mm}$.

Two taken in the open estimated as a day or two old were as follows:

$\begin{array}{ccccc}\text { No. } & \begin{array}{c}\text { Total } \\ \text { length }\end{array} & \begin{array}{c}\text { Tail } \\ \text { vertebrae }\end{array} & \begin{array}{c}\text { Hind } \\ \text { foot }\end{array} & \text { Weight (2 days later) } \\ 1 & 155 \mathrm{~mm} & 25 \mathrm{~mm} & 39 \mathrm{~mm} . & 133 \text { grams } \\ 2 & 158 \mathrm{~mm} . & 22 \mathrm{~mm} & 43 \mathrm{~mm} . & 183 \text { grams }\end{array}$

Of californicus, we have complete data for one litter ot four compiled from the living young one day after they were taken.

$\begin{array}{cccccc}\text { No. } & \begin{array}{c}\text { Total } \\ \text { length }\end{array} & \begin{array}{c}\text { Tail } \\ \text { vertebrae }\end{array} & \begin{array}{c}\text { Hind } \\ \text { foot }\end{array} & \begin{array}{c}\text { Ear from } \\ \text { notch }\end{array} & \text { Weight } \\ \text { Noth } & 140 \mathrm{~mm} . & 20 \mathrm{~mm} . & 33 \mathrm{~mm} & 30 \mathrm{~mm} . & 65 \text { gram. } \\ 2 & 140 \mathrm{~mm} . & 20 \mathrm{~mm} . & 34 \mathrm{~mm} . & 25 \mathrm{~mm} . & 66 \text { grams } \\ 3 & 140 \mathrm{~mm} . & 20 \mathrm{~mm} . & 36 \mathrm{mmm} . & 26 \mathrm{~mm} . & 71 \text { grams } \\ 4 & 140 \mathrm{~mm} . & 18 \mathrm{~mm} . & 33 \mathrm{~mm} . & 27 \mathrm{~mm} & 60 \text { grams } \\ \text { Av. } & 140 \mathrm{~mm} . & 19.5 \mathrm{~mm} . & 34 \mathrm{~mm} . & 27 \mathrm{~mm} . & 65.5 \text { grams }\end{array}$

* Since specimens that were naturally boin have not been available we judged when the foetuses were fully developed by the full-furted pelage, activity, lack of bleeding of the severed umbilical cord, and other indications of normality. 
From Texas, Bailey has recorded a litter of one taken from the mother: Total length, 204; tail vertebrae, 26 ; hind foot, 52 ; weight 2 ozs. Here again we see the individual in a litter of one exceeding in size any of a larger litter.

It is not physically difficult to feed young jack rabbits from the first, as they take milk readily from a medicine dropper and soon become expert at it. When a few days old they will drink from the tip of a teaspoon or even from an open saucer. After feeding, which usually results in smearing the face, the youngster washes its face in the manner of a cat.

From the dietetic standpoint feeding is not simple. We have tried cow's milk, creamy, ordinary whole, and diluted; and condensed milk diluted in varying degrees, only to have one little rabbit after another turn ill with digestive trouble in about 10 days and quickly die. Using cow's milk diluted with lime water one young L. californicus was successfully reared to maturity. A young Arizona jack estimated to be three or four days old was found in the open, June 14, 1930, its mother probably dead, as it was very hungry. Evaporated milk, undiluted. was used because there was nothing else available, and the young rabbit thrived until July 8 , when it broke a leg in attempting to escape from a boy fondling it.

Two instincts are particularly noteworthy in the young of either species. One of these, which might be called the "following" instinct, is exhibited by the young which will follow one about at night. The young rabbit will respond to movement of a hand or foot on the floor, especially to a light tapping or patting, similar to the thamping sound which rabbits make with their feet. The animal seems to respond to the sound alone, though the possibility of seeing the movements may not have been eliminated. At such times, the ears are held in an erect, attentive, position. Since the young are probably never in contact with the mother by day, this following instinct may be reasonably interpreted as the response of the young to the coming of the mother at night.

The second noteworthy instinct is that of accepting food only at night. With all the disturbance of captivity, the young rabbits refuse a schedule of daylight feeding. By day the young jack rabbit rests quietly, inactive, crouching in a corner, even though perfectly free to move about in a whole room or house. It is indifferent to food and can scarcely be forced to accept any milk. By 4 or 5 o'clock in the afternoon it will take food more readily, but if left undisturbed will not move from its resting place until about dusk. It then becomes surprisingly alert and active, plays about its quarters, if sufficientiy roomy. or leaps out of bounds if possible. At night a youngster only a dozen hours old 
will leap out of a box several inches deep, but will remann quietly by day.

Nichol noted that a young Lepus alleni taken on July 8 showed the rump flash for the first time on Jaly 27 when alarmed and running.

Mary F. Taylor succeeded in rearing a specimen of L. c. eremicus to aditt size. This one when taken on July 10, 1923, weighed 254 grams; its ear from the crown measured $75 \mathrm{~mm}$. and its hind foot $65 \mathrm{mam}$. Although it was estimated to be about 3 weeks old, it would pay no attention to either green or dry alfalfa Sixteen days later it still drank milk greedily but showed some interest in hay. Its weight had increased to 493.7 grams (96 percent increase), and the measurements were as follows: ear from crown, $115 \mathrm{~mm}$ (53 percent); ear from notch $95 \mathrm{~mm}$. (49 percent); and hind foot $85 \mathrm{~mm}$ (30 percent). These measurements show that the ears of the newly born young are relatively short, but increase in size disproportionately during the first few weeks of life On July 28 , the jack rabbit ate some hay, though the staple diet was still milk. Daily weighings were planned and attempted about this time, but the animal was so terrified by the necessary handling that they had to be given up. It was active at night and wore a smooth path along the wire of its outdoor enclosure. By August 13 it was feeding on green alfalfa, and was very fond of green six-weeks grama. It did not like dry alfalfa, but was fond of green mesquite leaves.

When thoroughly alarmed the young rabbit would dash blindly against the wire of its cage, as if seized by an uncontrollable fear instinct. It played actively in the early morning. On September 13, when nearly 3 months old, it took milk eagerly in the absence of green alfalfa. It was still averse to dry feed if more sticculent material was available.

The little animal approached food or water in a hesitant way, as if it were not clearly seen but as if to hear or smell it This rabbit, although timid, appeared to recognize persons to whose presence it was accustomed, and showed alarm at the approach of strangers even at some distance. It was often nearly frantic with fear of a dog even at some distance, particularly after having been badly frightened by a dog barking at it just outside the cage. Some months later, however, it became accustomed to the presence of a neighbor's dog.

\section{FOOD}

\section{RABBITS AND VEGETATION}

Interrelations between hares or rabbits and vegetation have been given attention in many places. Important contributions have been made by the following: 
Clements (1916, opp. p. 150) illustrated degeneration of beechwood due to rabbits, Holt Down, Hampshire, England. The rabbit concerned was O1yctolagus cunculus, introduced into England from the Continent some time in the year 1100 .

Futchins stated (Baker, Korstian and Fetherolf, 1921, p. 310) that in England, France, and northern Europe, the rabbit was a constantly recurring trouble to foresters.

Matthams (1921, p. 227) wrote of some of the significant relations of rabbits, grass, and weeds in Australia.

Tansley (1922) reported on a study of vegetation of the English chalk, taking account of rabbit effects.

Orde-Powlett (1923) recorded extensive rabbit damage to sycamores in England.

Farrow (1925a, p. 135) concluded that biological factors should probably always be included with climatic and soil factors in ecological classification. Farrow pointed out the extreme mobility of the various types of vegetation owing chiefly to the differential influence of rabbits upon them. We might say, in comment, that possibly natural communities were always more mobile than we have recognized. The introduction by man of an undue weight of animal pressure, as by stock-grazing, has undoubtedly accentuated this mobility, both speeding it up, and giving it new, and sometimes rather unfortunate directions.

A landmark in the recent development of bio-ecology is Farrow's Plant Life on East Anglian Heaths (1925b). Farrow discusses the significant interrelations of rabbits, forest trees, and other forns of vegetation in England.

Allan (1926) discussed the effect of rabbit-grazing on the establishment of introduced plants in New Zealand, following severe burning or grazing.

Harmful effects of hares and rabbits in English woodlands and game coverts were studied in some detail by St. Clair-Thompson (1928, pp. $121-131,150$ ).

Lewis, Dowding, and Moss (1928) thought it probable that the influence of rabbits was greater in Alberta than in England owing to the long winter and scarcity of food.

Bird (1930) in one of the most important studies made to date of a terrestrial biotic community, concluded that rabbits were one of the four important factors tending to retard succession in the aspen park land of Manitoba.

Kittredge (1929) reported that snowshoe rabbits in Minnesota and adjacent northern Wisconsin, during 1923, 1924, and 1925 caused excessive losses in forest plantations and to all young forest tree growth. 
A semi-natural experiment involving rather extensive rabbit coactions with the vegetation and with other animals was reported by Couch (1930, pp. 334-336). The European rabbit was introduced on Smith Island, of the San Juan group, State of Washington, about 1900. By May, 1924, practically all succulent forage was cropped close to the ground.

Coutch has pointed out that on the Snow Creek burn, Olympic $\mathrm{Na}$ tional Forest, Washington, rabbits on some plots damaged 97 percent of planted seedlungs. An examination of this area in 1931 by Couch and W. P. Taylor, however, showed the injury much less serious than anticipated.

Johnson (1923, p. 28) reports the jack rabbit to be the worst animal pest with which the forester in the Great Plains region has to contend.

Burnett (1926, p. 5) suggested that distributional changes affecting two species of jack rabbits in eastern Colorado were associated with the invasion of the rabbit's original range by man.

Hanson (1929, p. 61, Fig. 4) illustrated a plot border in a Colorado sagebrush area (Laramie River valley) from which the sagebrush was cleared in the fall of 1927 . One side was protected from prairie logs and jack rabbits. On the other side the jack rabbits grazed heavily. A marked difference is clearly shown in the vegetation communities.

It was Hill's opinion (1928, p 91) that in the vicinity of Tucson, Arizona, heavy grazing by domestic livestock, very noticeably accentuated during recent years by rodents such as the kangaroo rat and the jack rabbit, was the greatest single contributing factor in the change from a grass type to a desert type.

At the Great Basin branch of the Intermountain Forest and Range Experiment Station at Ephraim, Utah, it was found that plantations of sweet clover, crested wheatgrass, and other species in artificial seeding tests were so heavily utilized by jack rabbits which congregated on the areas and grazed the seedlings that many of the trials were almost complete failures. It was necessary to construct fences around the plantations to exclude the hares.

The annual investigative report for 1930 of the Central States Forest Experiment Station, United States Forest Service, recorded 50 percent of Scotch pine in a new plantation near Columbus, Ohio, damaged by rabbits. From the director of the station we later learned that the recovery from rabbit injury has been phenomenal even in instances of very severe damage. Recent unpublished work of Cooperrider of the Southwestern Forest and Range Experiment Station indicates a remarkable recuperative ability on the part of conifers, mostly western yellow pine, injured by browsing of cattle, sheep, or game near Flagstaff, Ari- 
zona. Pearson, Krauch, and Lexen at the same station (Pearson, 1931) have further shown this by some excellent repeat photographs. In estimates of rabhit or other damage of the same trpe the complete story has not been told until the injured seedlings or plants have been followed through for several years. Initial injury may not be so serious as it appears.

We know little of the original relations betw een the jack rabbits and the vegetation. We may fairly assume, perhaps, a fluctuating equilibrium between the animals and their plant food. In drouth periods the plants would undoubtedly be hard pushed by the animals, which in turn, would doubtless suffer a recession in numbers through lack of proper food and so permit the recovery of the plants. In all probability. the plant-animal community, though varying widely: and never twice the same, did after all maintain a fairly definite status and trend.

The entrance of man on the scene, with his flocks and herds, and his tendency, often short-sighted, toward immediate conversion of natural resources into cash, profoundly disturbed the original fuctuating equilibrium, and substantially altered the slow, secular trend theretofore prevailing. Livestock now grazed and trampled the plants until in many cases the turf was broken up, the soil became exposed, leached. and eroded, and the way was opened for the incursion of secondary shrubs and weeds where formerly the climax grasses held sway.

Present-day observations of the coactions of jack rabbits and vegetation must be made with this background in mind. The habitat is changed, the vegetation modified, the soil altered, the successional trend interrupted. The present-day situation is a new development; indeed. there is a different equation in each locality. Up-to-date handling of the rabbit and other organisms will have to take full account of the local as well as the general situtation. The incidence of damage on a given aren often varies directily with the degree of departure from natural conditions. Some modifications by man which often result in a "rabbit problem" are: (1) overgrazing. (2) cutting of timber, (3) reclamation. $i$ s., introduction of farm crops on wild lands, (4) misapplied control of natural enemies of rabbits. The obvious conclusion is that modifications in course of agriculture, range management, silviculture, wild life regulation, and other enterprises involving land use should be held to a minimum.

By far the most serious rabbit effects recorded in human experience have restilted from introduction of the arimals in localities where they were not native. The Smith Island incident is a minor but illuminating instance of this. A spectacular demonstration on a well-nigh continental scale is afforded by the rabbit in Attstralia. 


\section{QUANTITY OF FOOD EATEN \\ FEEDING TESTS AND COMPUTATIONS}

A feeding test made by Taylor on an average-sized wild Lepus californicus affords at least a hint as to the amount of food consumed by jack rabbits as compared with forage eaten by sheep and cattle.

Data derived from 23 daily feedings with green alfalfa and grama grass follow:

\begin{tabular}{|c|c|}
\hline & $\begin{array}{c}\text { Grams } \\
307.4\end{array}$ \\
\hline 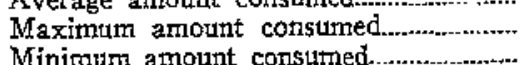 & $\begin{array}{l}631.1 \\
146.5\end{array}$ \\
\hline
\end{tabular}

Consultation with McGinnies and Stanley of the Arizona Agricultural Experiment Station, and reference to Henry and Morrison (1017, pp. 667.668) establish the fact that a 120-pound ewe will consume approximately 8 pounds of green feed in a day. At the rate of constumption of feed by rabbits according to the determination given aloove we obtain the following:

Number of rabbits required to eat as much green feed as one sheep:

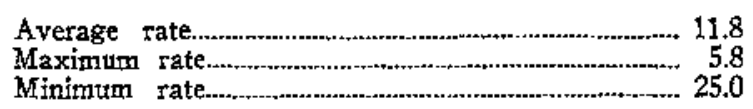

A 750-pound cow will consume 40 pounds of green roughage in a day. From this we obtain the following:

Number of rabbits required to eat as much gtcen feed as nge cnw:

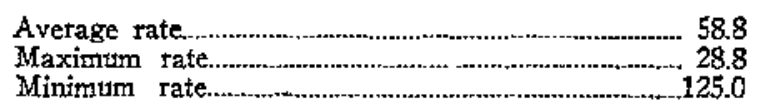

Data derived from eight daily feedings with air-dry aifalfa follow:

\begin{tabular}{|c|c|}
\hline 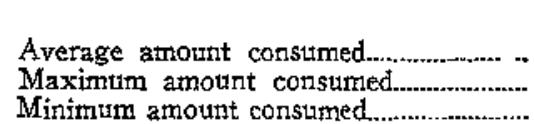 & $\begin{array}{l}\text { Grams } \\
128.1 \\
165.6 \\
107.1\end{array}$ \\
\hline
\end{tabular}

A 120-pound ewe will consume approximately 4 pounds of air-dry feed in a day. At the rate of constumption of feed by rabbits according to the determination given above we obtain the followirg:

Numlyer of rabbits required to eat as much air-dry feed as one sheep:

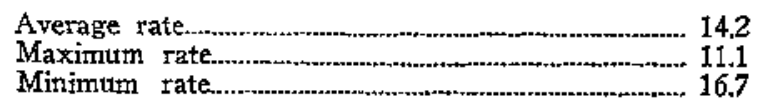

A 750-pound cow will consume approximately 20 pounds of air-dry feed in a day. At the rate of consumption of feed by rabbits according to the determination given above we obtain the following: 
Number of rabbits required to eat as much air-dry feed as one cow :

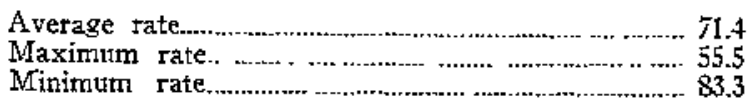

The above figures are conservative. In some instances the rabbit would have eaten more feed if it had been available.

M. C. Smith of the Arizona Agricultural Experinent Station, finds that white rats eat about 6 percent of their weight of air-dry feed in 24 hours. Of succulent feed they eat at least twice that amount, and sometimes even more than that. Something like the same percentage relation of food consumed to weight of animal may obtain in rabbits as in white rats. By using these figures we can check our previous experimental determination of the "jack rabbit equivalent" of sheep and cows. The figures follow:

\section{LEPL'S CALIFORYICIS}

Weights of animals..

$\begin{array}{cc}\text { Average } & \text { Minimum } \\ \text { Pounds } & \text { Pounds } \\ 5.47 & 4.37 \\ .3282 & .2622\end{array}$

Maximum
Pounds
7.5
.4500

Six percent of these weights.........

Taking the amount of dry feed consumed by one sheep in one day as 4 pounds, green feed 8 pounds, and the anount of dry feed consumed by one cow in one day as 20 pounds, green feed 40 pounds, we derive the following sheep-jack rabbit equivalent (number of rabbits which will eat as much as one sheep in one day, either dry or green feed):

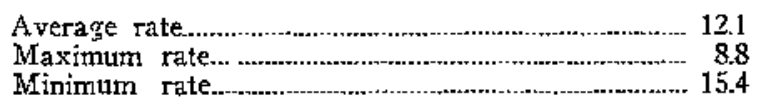

The cow-jack rabbit equivalent (number of rabbits which will eat as much as one cow in one day, either dry or green feed):

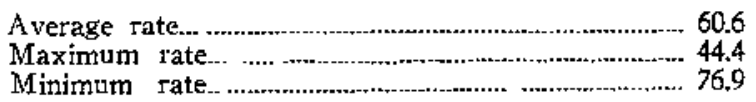

\begin{tabular}{lccc}
\multicolumn{4}{c}{ LEPES ALLENI } \\
& Average & Minimum & Maximum \\
& Pourds & Pounds & Pounds \\
Weights of animals...................... & 8.062 & 6.062 & 13.0 \\
Six percent of these weights....... & .4837 & .3637 & .7800
\end{tabular}

Sinilarly determined, the sheep-jack rabbit equivalent for Lepus alleni is:

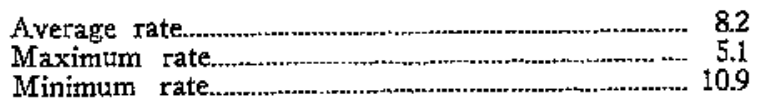


The cow-jack rabbit equivalent for alleni is:

$\begin{array}{ll}\text { Alerage rate } & 412 \\ \text { Waximum rate } & 255 \\ \text { IInimum rate } & 54.8\end{array}$

The calculated check is not far from the experimental results of green-feed tests. On the average. the sheep-jack rabbit equivalent for Lepus californicus is about 12.7, and the cow-jack rabbit equivalent about 63.6. For L. alleni the sheep-jack rabbit equivalent is about 8.2, the con-jack rabbit equivalent about 41.2 .

Another check is afforded by Matthams (1921. pp. 40-43) who gives an estimate apparently current in Australia that $121 / 2$ rabbits eat as much herbage as is required to sustain one sheep. The similarity of the Australian estinate to otur own is of interest.

\section{CORRECTION IN EQUTVALENTS}

Since on the basis of our figures, Lepus allemi consumes 44 percent ( 36 percent mesquite and 7.8 percent cactus) of materials in the taking of which it does not appreciably compete with cattle, the cow and sheep equivalents for this jack rabbit require correction. According to figures previoutsly given (p. 515), the sheep equivalent for the species is 8.2, and the cow equivalent 412 . A computation based on the 56 percent of its food (grasses, etc.) which bring the rabbit into competition with cattle, shows that, on the average, the antelope jack rabbit will eat but 0.27 pound of dry feed in a day. On this basis 15 antelope jack rabbits would be required to eat as much as one sheep, or 74 as much as one cow.

On our figures 59 percent of the food of 4 . californicus is of neutral character, mesquite 56 percent, cactus 3 percent, while but 41 percent (grasses, etc) brings it into competition with either sheep or cattle. Thus, but 0.135 pound of feed of which livestock is thereby deprived is consumed by the Arizona jack rabbit in a day. This means that 30 Arizona jack rabbits would eat as much as one sheep, or 148 as much as ? cow.

\section{FORAGE CONSUMPTION DY RODENTS}

A series of quadrats was clipped in connection with studies made on Plot 1A,* Santa Rita Range, in an encleavor to make a quantitative

\footnotetext{
* At plot 1A fences were erected in 1918 as follows (1) A 4-acre area was inclosed with five strands of barbed wire This fence kept out cattle but permitted the free entrance of rodents of all sorts. (2) A contiguous 2-acre area was inclosed with one-half inch mesh hardware cloth 3 feet high, with barbed wire above. This fence kept out cattle, rabbits, and large kangaroo rats. Smaller rodents, and woodrats which can climb the fence, were not excluded. The quadrats were located alnng a transect line through the totally protected plot, the rodent-grazed plot, and the area outside all the fences.
} 


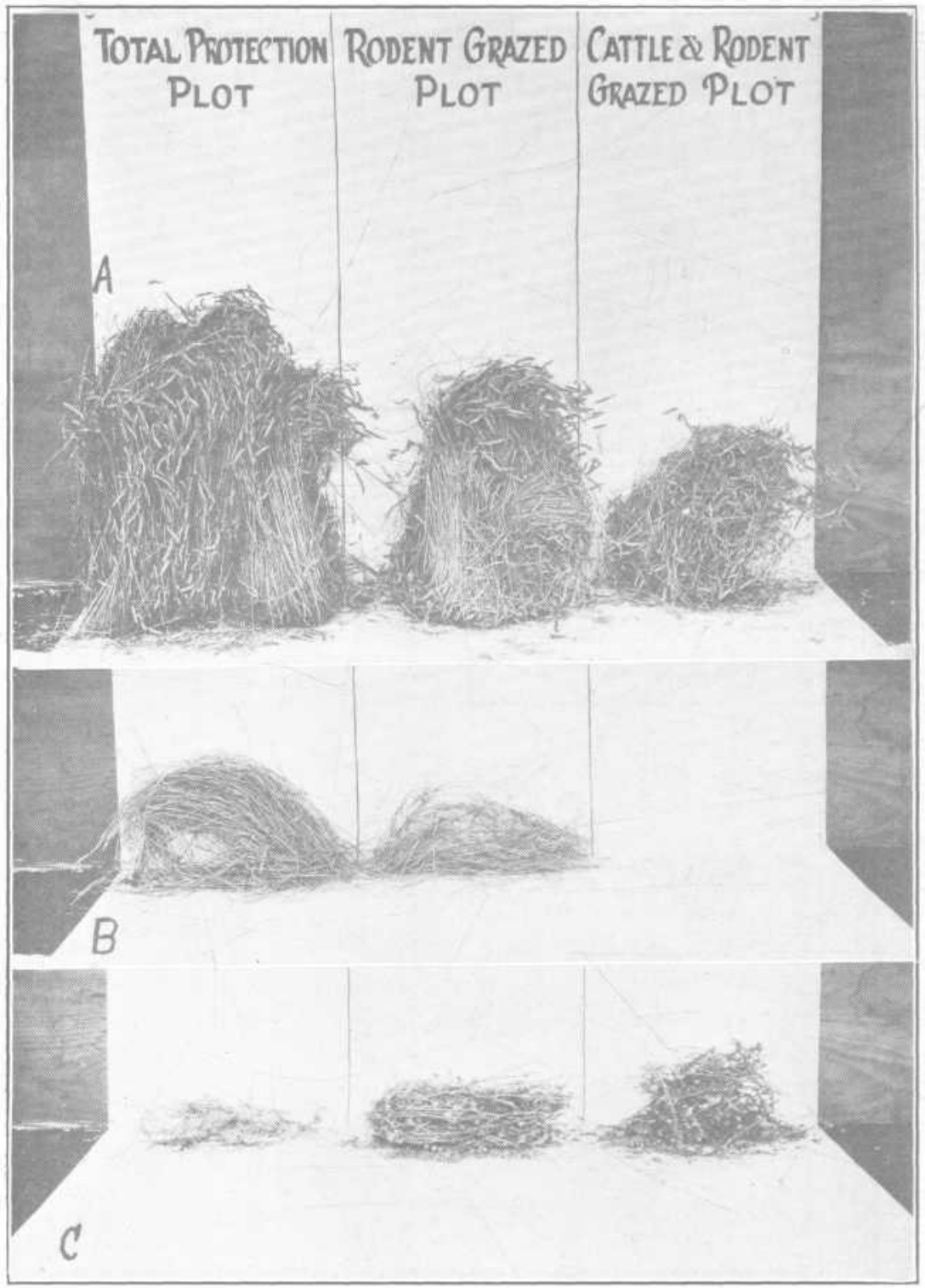

Plate 5.-Vegetation clipped from meter quadrats (Plot 1A, Santa Rita Range) under; total protection from livestock, rabbits, and large rodents; grazing by rabbits and rodents, protected from livestock; grazing by livestock, rabbits, and rodents; A, Bouteloua rothrockii; B, Aristida californica; C, Weeds, mostly mallow, Franseria sp., Portulaca, etc. 


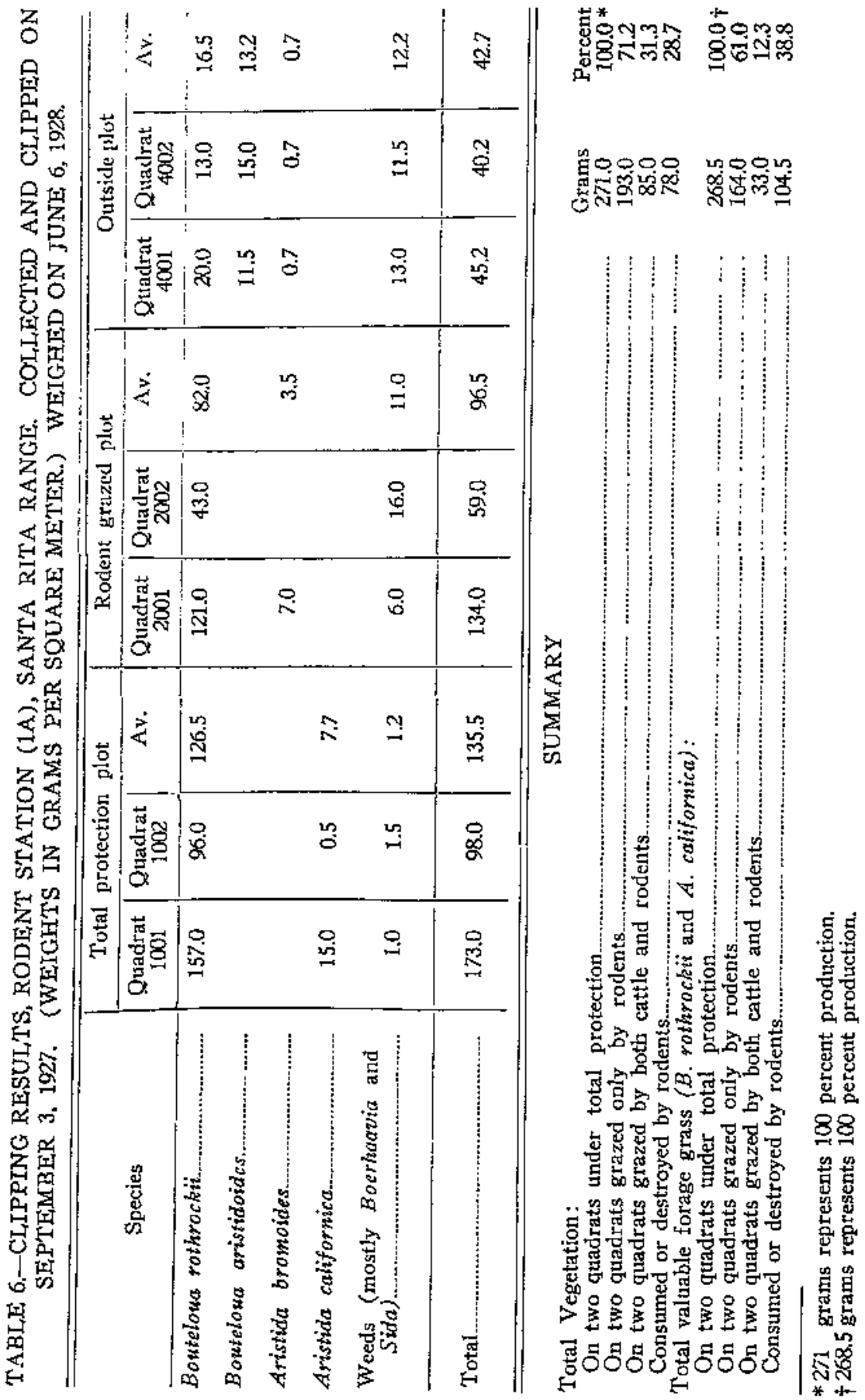


determination of the actual amount of vegetation consumed by rodents (Plate 5). The results are given in Table 6. While Lepus alleni, occasionally Lepus califonicus, and Difodomys spectobilis, occur in the vicinity and graze over the rodent plot and the outside areas, $L$. allcni is chiefly responsible for the consumption of vegetation indicated.

The data are meager and consequently subject to considerable error but constitute definite indications of a trend. It will be noted that 28.7 percent of all the vegetation, and 38.8 percent of the most valuable forage grasses on this particular area, had been consumed or destroyed by rodents. Later in the season it is quite possible that the contrasts would be even greater. Peilet counts (Taylor, 1930. pp. 531-534) taken at the same time, indicated no concentration of rabbits on the rodent-grazed plot. The quadrat results do not include browse species or grass cut by rodents and left lying.

In addition to the quantitative results derived from quadrat study. evidences of rabbit work on vegetation at the experimental plots are conspicuous. Rabbits feed on various species of browse, consume cactus, work on weeds, and make excavations for succulent roots, producing effects evident in the todent-grazed plot, but lacking in the totally protected plot (Plate 7). Table 7 gives some comparisons.

TABLE 7.-WORK OF JACK RABBITS AT RODENT STATION (IA).

(February 20-21, 1925.)

\begin{tabular}{l|c}
\hline Rodent-grazed plot & Total protection piot \\
\hline $\begin{array}{l}\text { Many raßbit trails and feces through } \\
\text { the grass. }\end{array}$ & Rabbit trails and feces lacking. \\
$\begin{array}{c}\text { Clumps of grass smaller, more numer- } \\
\text { ous, grass shorter. }\end{array}$ & $\begin{array}{c}\text { Grass clumps larger, less numerous, } \\
\text { grass taller. } \\
\text { Smaller mesquite branches near } \\
\text { ground chewed off. }\end{array}$ \\
\hline
\end{tabular}

\section{FOOD OF JACK RABBITS AS SHOWN BY STOMACH ANALYSES}

Stomach analyses have proved far more useful in determining food habits of rodents than anticipated. They must be supplemented, however, by every other practicable type of study of the animal in question, if a true picture of the food habits of the arimal is to be obtained. 


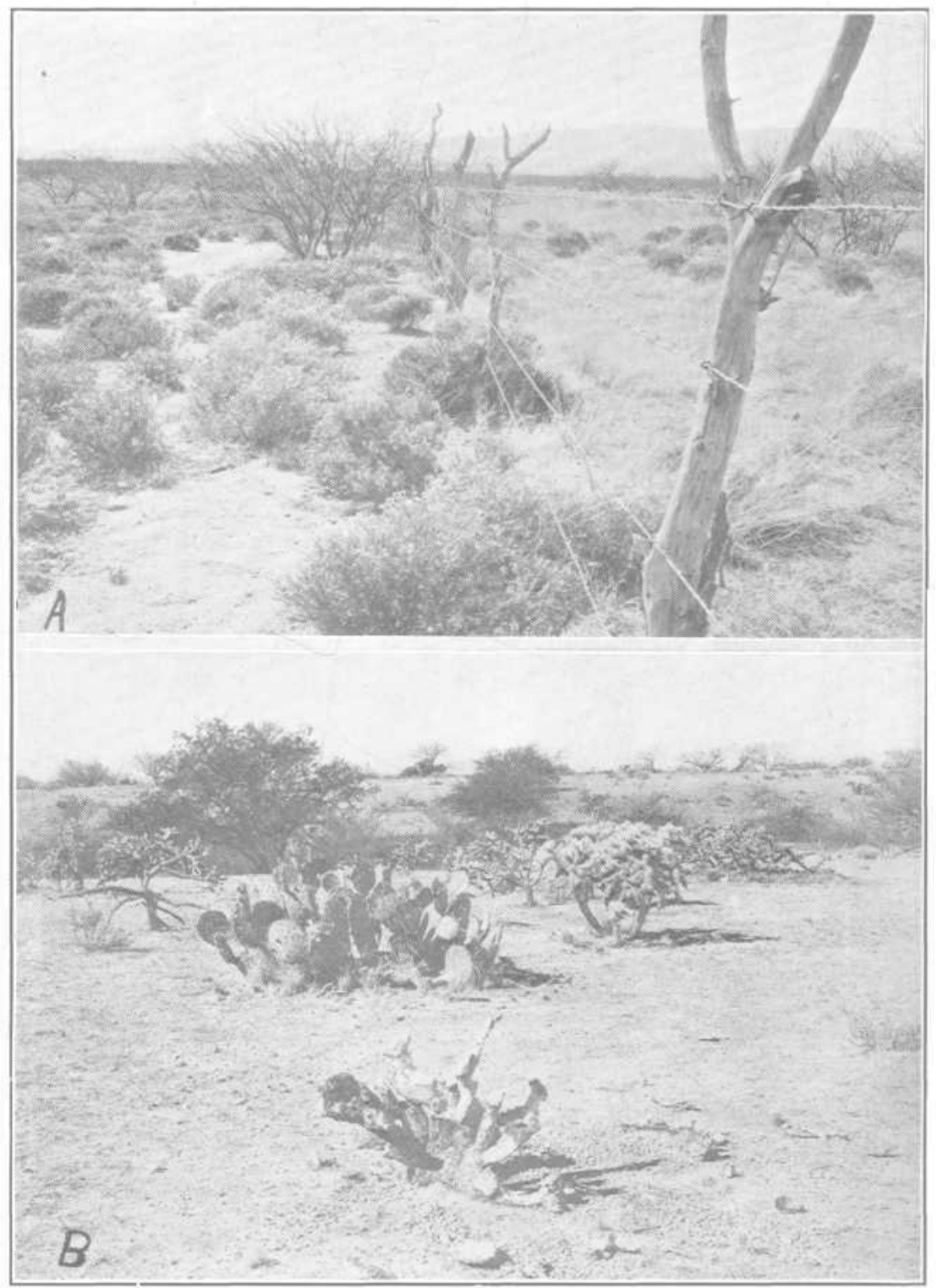

Plate 6.-A, Illustrating differences in grazing pressure, Plot 1A, Santa Rita Range. Pressure of livestock, rabbits, and rodents (on left) is indicated by a heavy growth of burroweed and absence of grass. Pressure of only rabbits and rodents (on right) is insufficient to prevent good growth of grass, which hinders establishment of burroweed; B, The prickly pear in the foreground has been almost consumed by jack rabbits (note abundance of pellets), while that in the middle distance is untouched. Santa Rita Range. 


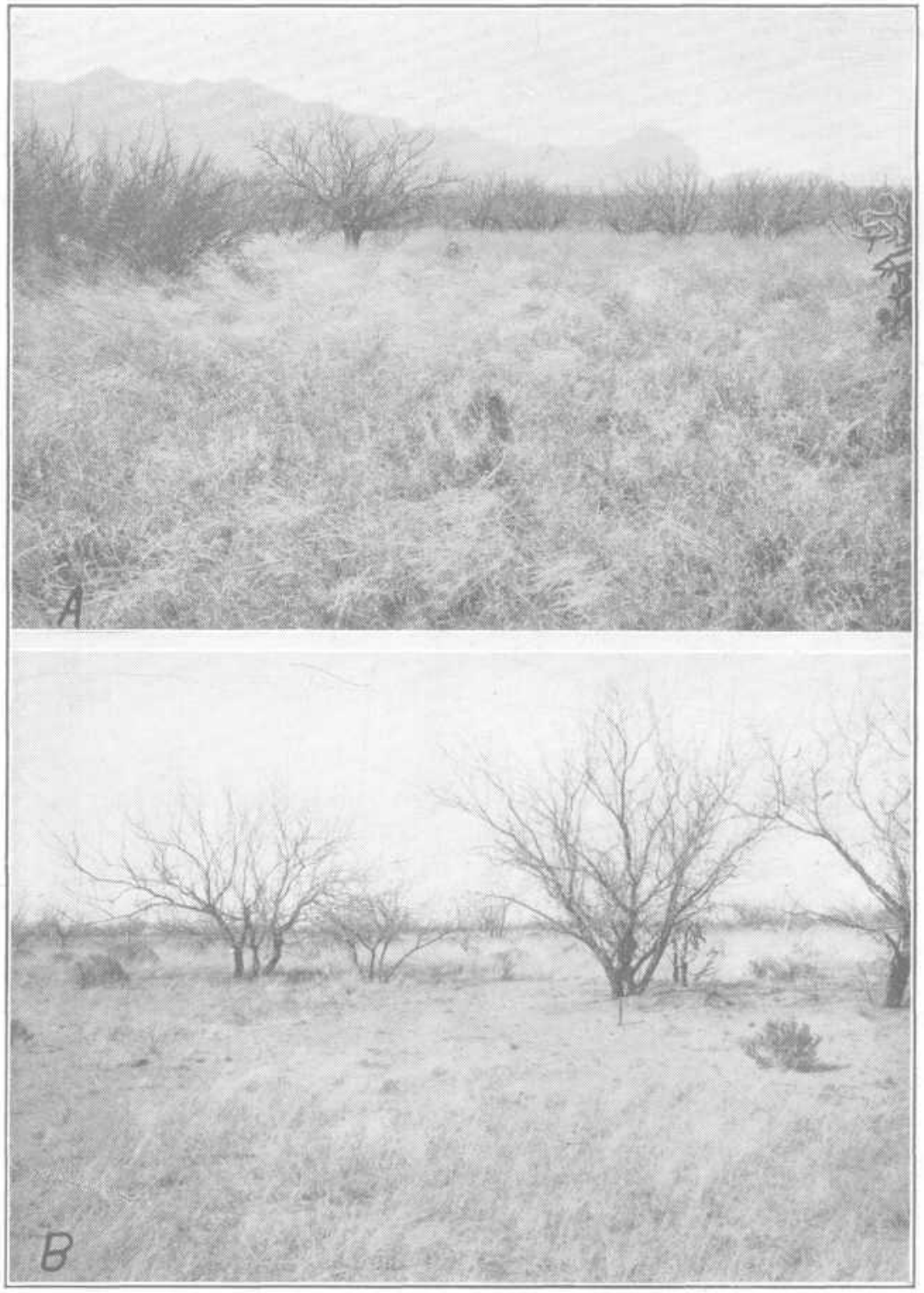

Plate 7.-Comparison of grass under total protection and protection from cattle (Plot 1A, Santa Rita Range). A, Plot totally protected from cattle, rabbits, and larger rodents; B, Plot protected only from cattle, open to rabbits and rodents. The bare area in the middle, near a kangaroo rat den, somewhat over-emphasizes the effects of grazing by rodents and rabbits. 
Stomach contents do not indicate the extent of root and tuber consumption by jack rabbits, nor do they give an adequate list of the plants actually ingested, especially of anmuals. Many substances consumed, as bark (outer and inner) of shrubs, and roots, stems, and leaves of miscellaneous herbs cannot ordinarily be identified in the stomach. Rabbits are sometimes observed feeding on tiny green plants growing on the ground. Rabbit stomach examinations give little or no record of such materials.

\section{LEPUS ALLENI}

Analyses have been made of 179 stomachs of alleni for the most part taken on the Santa Rita Range. All months of the year but one (January) are represented. The food material in each stomach was regarded as 100 units, and all stomachs were totalled, making 17,900 units. The units of different foods in each stomach were carefully determined, and the totals added. (Thble 8.) Thus 6,342 units, or 36 percent, of the food for the entire year were mesquite; 7,988 units, or 45 percent, grass; and 1,404 units, or 7.8 percent, cactus, with lesser amounts of other materials.

The food of jack rabbits in the southern Arizona region is intimately related to the alternating dry and rainy seasons, (see Table 3 , Correlation of Precipitation and Breeding Rate, and Fig. 2). Following the winter rains, when a number of the perennial grasses put forth leaves, the percentage of grass in the diet markedly rises, while the amounts of mesquite and cactus consumed decrease almost to the vanishing point. During May and June, the most arid period of the entire yeas, the grass dries up, and is much less eaten, while mescuite maintains a high percentage in the diet and cactus increases. In July and August, following the summer rains, grass becomes by far the most important item in the diet, forming 80 percent of all food eaten in July and 84 percent in August. Mesquite falls to its lowest point for the year at this period of maximum grass development, and cactus also decreases. Through the fall months the proportion of grass in the diet declines somewhat, while that of mesquite increases, approximately in inverse proportion. While deciduous, the mesquite does not shed its leaves in early autumn; in fact some leaves remain on individtral trees all winter.

Cactus does not appear in the stomachs in anything like the quantity anticipated. In a general way the cactus graph follows that of mesquite. The most cactus is consumed, apparently, in winter, when the grass is drier than at any other time of year except the arid fore-summer (May-June). 


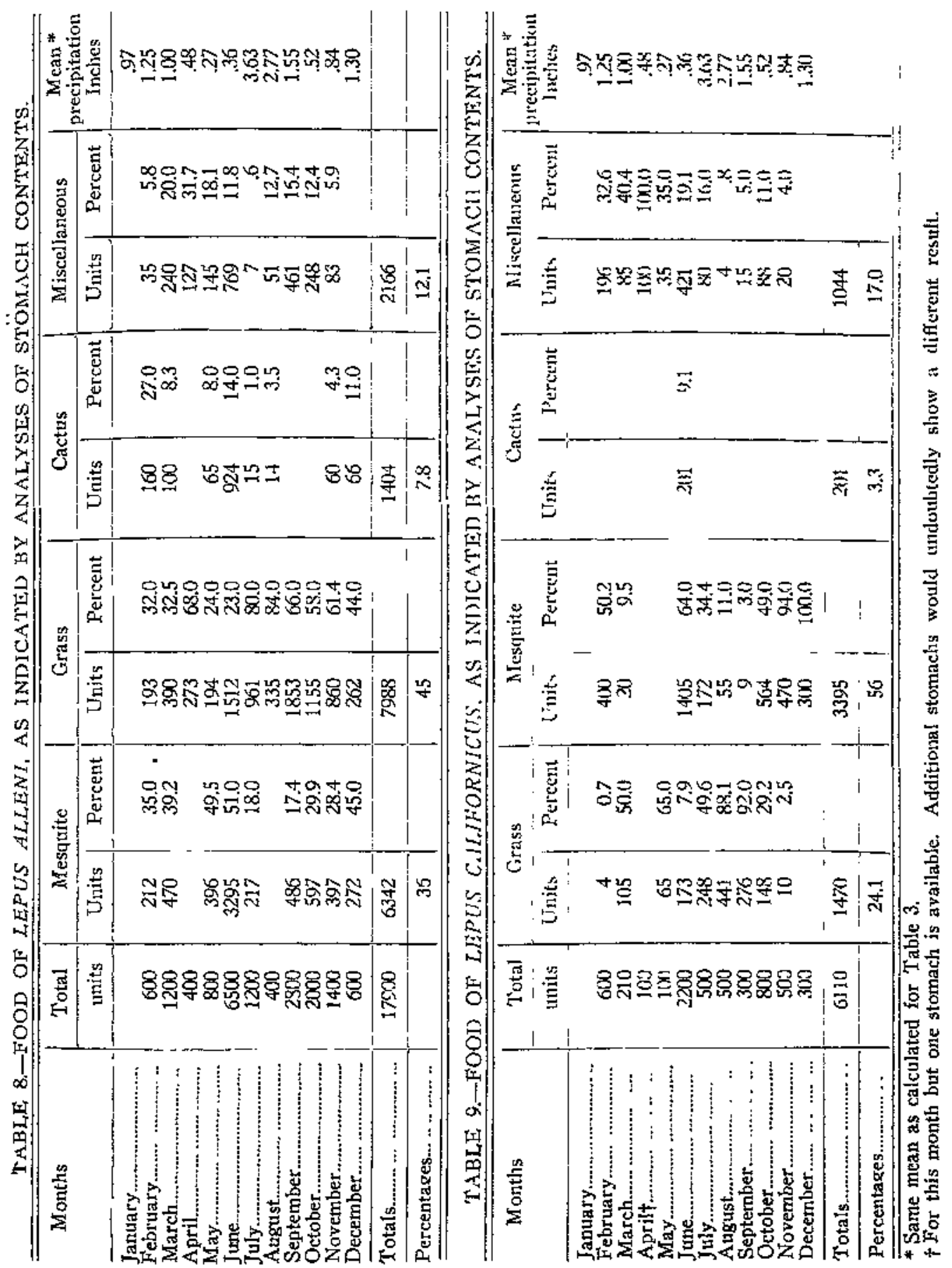




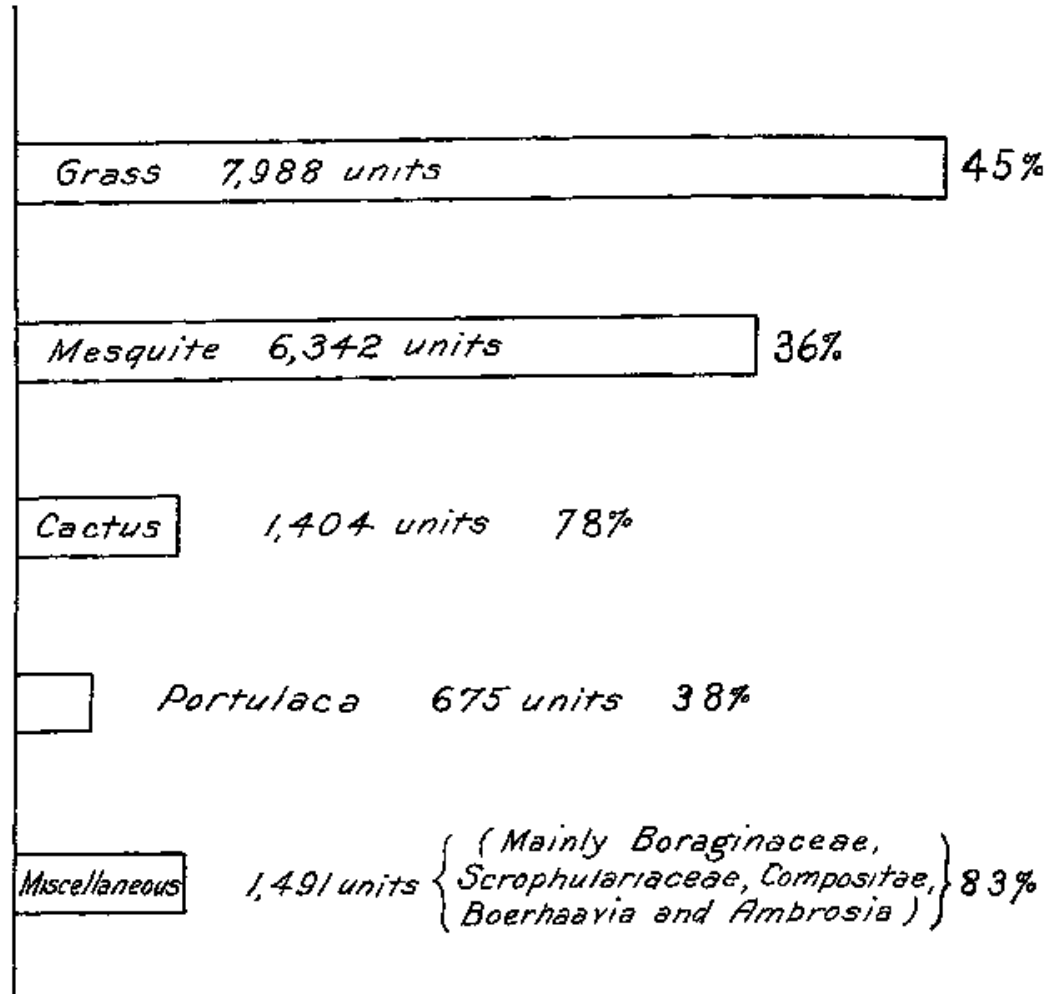

Fig. 2-Percentage consumption of food of L. alleni throughout the year

Food materiais jncluded under "Miscellaneous" in Table 8 are: Portulaca, 3.8 percent (of all food) ; Boraginaceae, 2.3 percent; Boerhaavia, 2.2 percent; unidentified Scrophulariaceae, 0.53 percent; Ambrosia, 0.16 percent; Compositae, 0.08 percent; and traces of the following: $A$ morpha, Euphorbiaceae, Amaranthus, Eriogonum, Mollugo, Sida, Geranium, Solidago, Malvaceae, a few unidentified herbaceous plant parts, Calandrinia or Oreobroma (?), Plantago, Daucts, Atriplen, Karwinskia (?), Alsine, Fabaceae, Cirsimn, Umbelliferae, Cruciferae, Calliandra, Juncus, Sideranthus, Salsola, Leguminosae, Rosaceae, Artemisia, Pentstemon, Solanaceae, and insect remains. Seeds, leaves, and stems of these miscelianeous plants are variously eaten. Availability of food materials and accident of capture of individual rabbits have much to do with the food found in the stomach.

\section{LEPUS CALIFORNICUS}

Analyses have been made of 61 stomachs of californicus, taken principaliy on the Santa Rita and Jornada Ranges. As with alleni, the food 


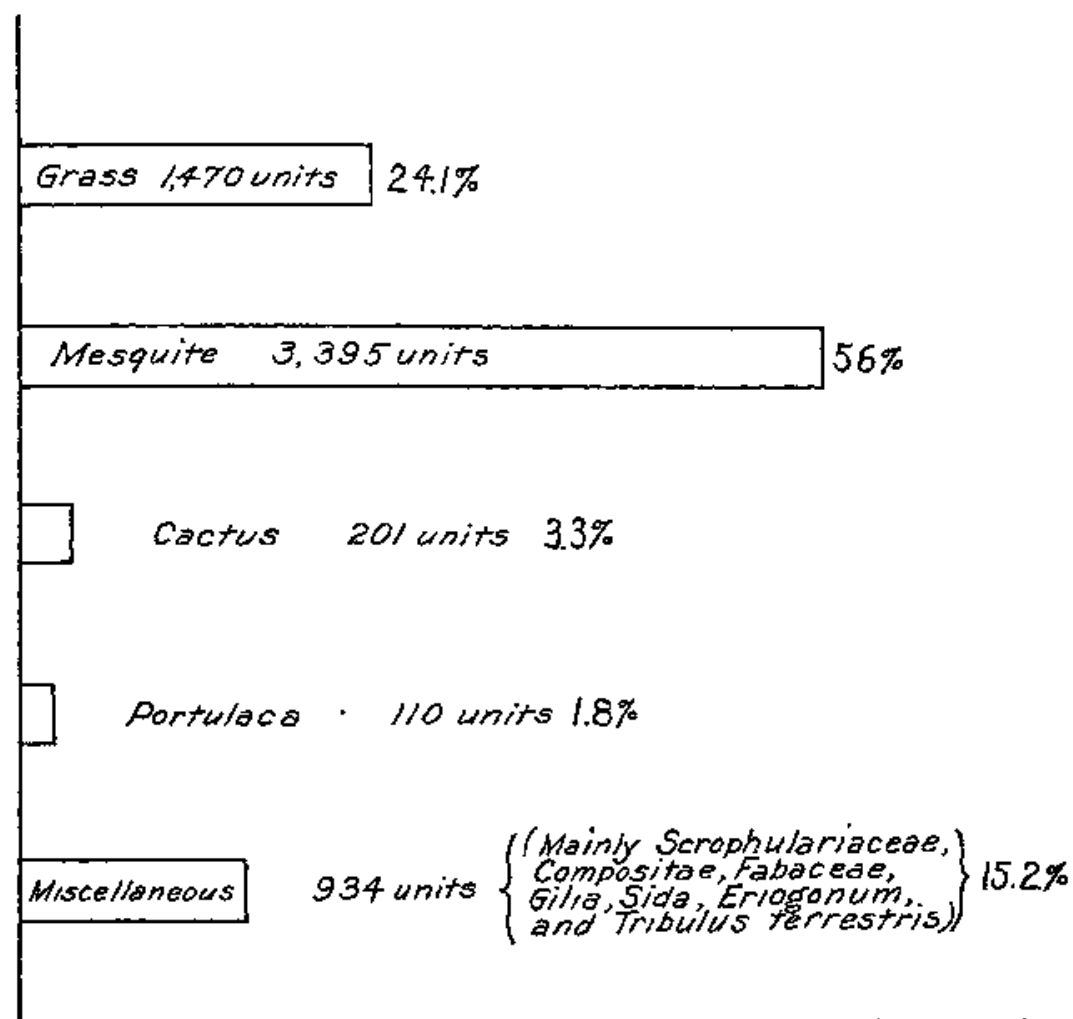

Fig. 3.-Percentage consumption of food of $L$. californicus erewticus throughout the year.

material in each stomach was regarded as 100 units, and all stomachs were totalled, making 6,100 units (error in one of the office analyses makes the total 6,110 instead of 6,100 , but the results are not affected). The units of different foods in each stomach were carefully determined, and the totals added (Table 9). Thus, on this record, 1,470 units, or 24 percent, of the food for the year were grass; 3,395 units, or 56 percent, mesquite; and 201 units, or 3.3 percent, cactus. Smaller amounts of other materials were recorded.

The graph (Figure 3) and Table 9 show that, in these stomachs, grass and mesquite together made up 80 percent of food taken. Strangely enough, twice as much mesquite as grass was consumed. The amount of cactus was small; that of miscellaneous plants appreciably larger than in $L$. alleni.

An inverse relation between the consumption of grass and mesquite is even more strikingly shown by $L$. californicus than it is by $L$. alteni. 
As in that species, grass consumption has two peaks, one in the months following the winter rains, the other in midsummer and early fall follow ing the stmmer rains. In the fall and early winter grass consumption markedly drops. At this period the eating of mesquite reaches its highest level, declining in the late winter and early spring, inversely with the winter growth of grass, and reaching a second peak as the arid fore-sumimer is approached.

Miscellaneons food items in the $61 \mathrm{~L}$. californicus stomachs included the following: Amaranthus (seed), Boerhaavia (seeds, leaves), Mollugo (seeds), Compositae (seeds, leaves, bracts), Euphorbia (seeds, pods, capsules), Pentstenon (leaves), Tribulus terrestris (fruit), Eriogonum (leaves), Scorphulariaceae, Erodium, Daucus (seeds), Plantago (seed). Cirsium (leaves), Astragalus (frtiit), Chenopodiaceae, Odostcmon (leaf), Mimosaceae (leaves), Sida (leaves and stems), Cruciferae (pods), Amaranthaceae (seeds), Portulaca (leaves, seeds, pods, stems, and roots), Artenisia (leaves and twigs), Umbelliferae (seeds), -Atripler (leaf and frtut). Malvaceae (leaves, seeds), Karzuinskia (?) (seed fragments), Gilia (leaves), Ceanothus (leaves), Fabaceac (leaves). Silenaceae (seeds), and Amorpha (leaves).

\section{JACK RABBITS AND BROWSE}

Browse is a very large item in the yearly food of jack rabbits. Among the species to which the animals give attention in the Southwest are: mesquite (Prosopis), catclaw (Acacia greggii), acacias (A. constricta and suffrutescens), palo verde (Parkinsonia microphylla), crucifixion thorn (Koeberimia spinosa), soapweed (Yucca elata), chamiza (Atriples cancscons), jointfir (Ephedra trifurca), creosote bush (Cozillea tridentata), blackbrush (Flourensia cernua), snakeweed (Gutierrezia juncea) and $Z i r y p h u s$ sp. (?). Railey records jock rabbits feeding on Sarcobatus vermiculatus near Kelton, Utah, and Jewett says in eastern Oregon in winter they feed on sagebrush. In a dry season (June, 1929) near Seligman, Arizona, Taylor noted that bark and new shoots of Chrysothammus were being extensively eaten.

On March $\%$, 1931, an antelope jack rabbit was seen browsing from a small burroweed (Isocoma coronopifolia), most of the shoots of which had been cut off. The observation is unusual, and should not be regarded as indicating extensive work by the rabbit on this poisonous plant.

\section{MESQUTTE}

Far more important, in the Southwest, than their effect on any other species of browse is the work of jack rabbits on mesquite. No other 
species of brush was present in sufficient quantity to figure in the stomach analysis tables. Mesquite, on the other hand, is one of the principal foods of the jack rabbits in this region, forming 36 percent of all food of L. alleni and 56 percent of all food of L. califormicus. As already shown, mesquite is the great alternative to succulent grass. When green grass is available mesquite is not eaten to any extent. Whenever the supply of succulent grass declines, the consumption of mesquite increases.

Careful comparison of mesquite trees protected from and exposed to jack rabbits shows that they regularly snip off many of the lower branches keeping the trees "aerated." There is no question that, in the absence of jack rabbits, the mesquites in the Santa Rita region would be bushier toward the ground. We have seen no evidence, on the Santa Rita Range, of rabbit work handicapping the growth of mesquite. On the contrary, Prosopis appears to be thickest where overgrazing by stock and rabbits is most pronounced. In all probability the work of jack rabbits favors the growth of mesquite through removal of perennial grasses. Elimination of competing tufts of these grasses must favor the establishment of mesquite seedlings.

In browsing from mesquite the rabbit rears up on its hind feet, its fore feet hanging limp, its ears fopping freely; or, wishing to reach higher, stands on its toes, places its fore paws on a branch partly for support and partly to hold down the branch, and proceeds to crop off leaves, bark, or buds. It is especially fond of the tufts of green leaves which appear in the axils of the mesquite spines.

During severe seasons jack rabbits may seriously injure mesquite or other species of browse through gnawing the bark. We have observed instances where the bark was stripped for a distance of 2 feet. Stems within 3 feet of the ground and up to 1.5 inches in diameter may be gnawed. Serious work of this kind is extremely rare. In southern Cochise County and eastward into New Mexico, the mesquite is of a dwarf form and some plants occasionally receive attention from jack rabbits. There is a possibility that where local climatic or soil factors somewhat inhibit the growth of mesquite, the rabbits also may help to preserve the dwarf form of the bushes.

Aldous has pointed out that "In sandy areas on the Jornada Range Reserve, New Mexico, which have been overgrazed the rabbit may have a beneficial influence on helping restore the range. Where sand is abundant and overgrazing practiced it is but a short time until the grass is gone and the sand in a drifting condition. One of the first steps of a come-back is the growth of mesquite. The small bushes act 
as wind breaks and gradually the sand envelopes a good portion of the bush. The butied stems send out new shoots and the mesquite clump increases in size, as does also the sand dune. One of the chief foods of the rabbit during the winter and spring months is mesquite bark. This girdling and stripping of the bark naturally injures the plant and it responds like most girdled trees in that new shoots come from below the sand. The mesquite clump grows and becomes larger and more dense, thus preventing mutch of the drifting especially during the summer and allowing smailer annuals and perennials to take hold. One of the most important plants in this come-back process is the snakeweed (Gutierrezia jurcea) which makes a good cover over the whole surface. It is among this snakeweed that the climax grasses, such as gramas, get their start."

\section{OTHER SPECIES}

In all probability jack rabbit work is favorable to the spread, not only of mesquite, but most of the other species of browse. By grazing the perennial grasses (the chief competitors of browse seedlings) the rabbits, although they may nibble the mature plants and consume some seedlings, favor the browse species by injuring their competitors even more. It will be recalled also that aside from mesquite, alnost no browse appears in the stomach analyses. Field observations, however, show widespread diffuse work on browse.

In drier seasons catclaw (Acacia greggii) is regularly given attention by jack rabbits. Bark may be gnawed from larger stems, the terminal portions of branches constumed, twigs from $1 / 16$ to $1 / 3$ inch in diameter cut, and small leaf-buds chewed off. $A$. constricta also may be somewhat peeled and girdled. Occasionally $A$. suffrutescens is attacked.

While unpalatable in appearance, the terminal branches of the jujube

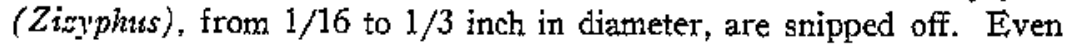
palo verde (principally Cercidium microphyllum) stems from $1 / 16$ to $1 / 4$ inch in diameter may be severed. While ordinarily palo verde is not eaten, individual shrubs are browsed to a height of 3 feet, and occasionally one finds all accessible twigs gnawed by jack rabbits. Small bushes, as much as 3 inches in diameter at the ground, may be seriously injured or even killed. The wood and foliage of hackberry (Cellis paliida) are so tottgh and repellent that they are given little attention though tender terminal twigs may be severed. Where it occurs, blackbrush (Flourensia cernua) is gnawed, but usually not seriously. Small quantities of crucifixion thorn (Koeberlinia spinosa), and soapweed, (Yucca elata) are consumed. At rather long intervals we have observed rab- 
bit cutting on the creosote bush (Corillea tridentata); but in southern Arizona rabbits apparently do not browse this bush. If eaten at all, the amount actually consumed must be very small in proportion to the crutting.

We have observed obvious jack rabbit work on Baccharis inrightit (PIate $8, B$ ) on the Santa Rita Range, where apparently rodents alone are sufficient to prevent the occurrence of the species under the grazing conditions prevailing. Bailey reparts jack rabbits feeding on the yellow flowers of a trifoliate barberry near San Angelo, Texas.

C. P. Wilson (1928a, pp. 19-23; and 1928b, pp. 27-29) has pointed out the potential seriousness of jack rabbit damage to chamiza (Atriplc.r canescens) under conditions encountered in New Mexico. Wilson asserts that rabbit injury to this plant was frequently greater than that caused by cattle. Cattle did not nip the seedlings so low, nor were they so likely to eat the little plants but 3 or 4 inches tall. "The rather common habit, with rabbits, of eating only a fraction of the vegetation that they cut off makes possible greater injury than would otherwise be the case. They are particularly fond of the larger stens of young chamizas, apparently not caring so much for the leaves and smaller stems; many of which are left on the ground where the small bushes stood before being destroyed." In one set of plot experiments rabbits and smaller rodents destroyed 72 out of 79 young chamizas (protected from livestock but not from rodents), while 44 out of 138 young chamizas (totally protected) survived. Wilson believes that chamiza, winter fat (Eturotia lanafa), and other valuable forage plants would be found in considerably larger acreage on the ranges of the Southwest than they are at present if it were not for the depredations of rabbits and smaller animals. We wish to point out, however, that this heavy damage by rabbits is quite likely in part the result of an overgrazed condition, the perennial grasses having been largeiy eliminated, reducing the amount of food available. Inevitably rabbit pressure is more severe on remaining vegetation.

\section{JACK RABBITS AND CACTUS}

While the stomach analyses show less cactus eaten by jack rabbits than expected, nevertheless, the animals feed on cactus in all drier times of the year.

Not all species of cactus are equally worked tpon. The writers have direct evidence of the eating by rabbits of the following species: Opuntia engelmanii and $O$. phaeocantha (prickly pears); Echinocactus wis- 


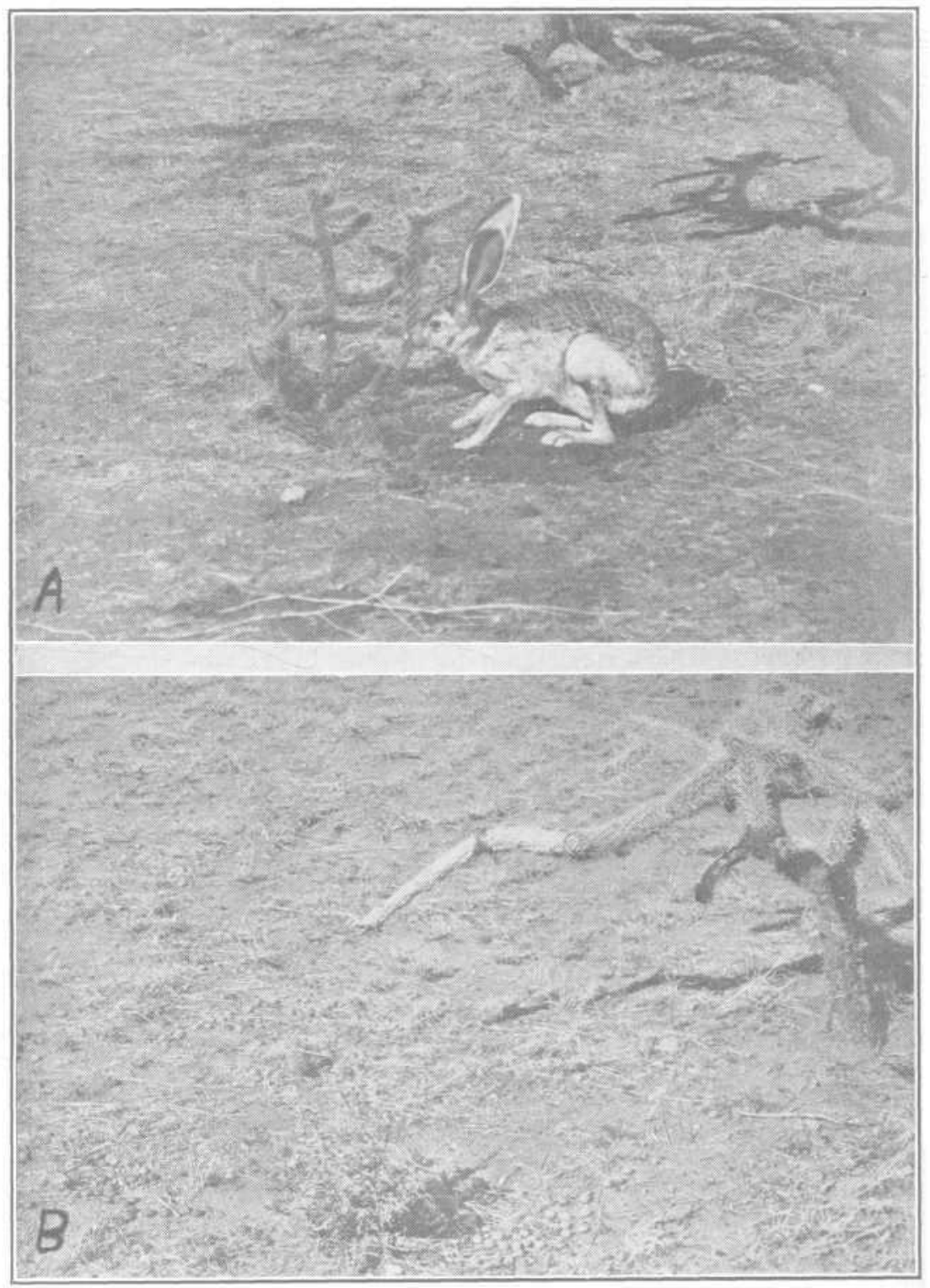

Plate 8,-A, This rabbit finds feeding on cholla cactus a delicate job. Note the white sides of this antelope jack rabbit: $\mathrm{B}$, Part of this cholla branch was stripped by jack rabbits. The plant, almost wholly consumed, in the extreme foreground, is Baccharis wrightii. Santa Rita Range. 
lisenii (visnaga); Opuntia fulgida and $O$. spinosior (chollas; Echinocereus fendleri (hedgehog cactus) ; Mammillaria sp. (pin-cushion cactus, Plate 10, B) ; Carnogia gigonted (giant cactus). Unquestionably others are eaten.

It is only natural that the least spiny species are most subject to rabbit attack. The prickly pear type is evidently more acceptable than the cholla (Plate 6, B). On a 4- or 5-mile walk in the Sopori Creek region (Pima County) 10 chollas and 39 prickly pears were observed. Of the chollas six showed no rabbit work, one light rabbit effects, and three serious work. Three of the prickly pears showed no rabbit effects, 8 were lightly and 7 moderately attacked, and 21 of the 39 , or $5+$ percent, seriously gnawed.

Table 10 gives the results of a much longer count made on the Santa Rita Range. The plants were examined just as they were encountered in walking actoss the country. The table shows that 50 percent of the prickly pears suffered heavy rabbit attacks, while but 2 percent of the chollas and none of the visnagas (in this partictlar count) were seriously attacked. Some additional counts and observations over a wide area and through more than 10 years, indicate the essential maintenance of this relationship except that, wherever the jack rabbits get a chance, they eat visnaga with every evidence of enjoyment.

TABLE 10.-JACK RABBIT WORK ON CACTUS, SANTA RITA RANGE. APRIL 1 , 1925 .

\begin{tabular}{|c|c|c|c|c|c|c|}
\hline \multirow{2}{*}{$\begin{array}{c}\text { Degree } \\
\text { rabbit } \\
\text { work }\end{array}$} & \multicolumn{2}{|c|}{ Prickly, pear } & \multicolumn{2}{|c|}{ Cholla } & \multicolumn{2}{|c|}{ Visnaga } \\
\hline & $\begin{array}{l}\text { No. of } \\
\text { plants }\end{array}$ & Percent & $\begin{array}{l}\text { No. of } \\
\text { plants }\end{array}$ & Percent & $\begin{array}{l}\text { No. of } \\
\text { plants }\end{array}$ & Percent \\
\hline Serious*.................. & 84 & 50 & 2 & 2 & 0 & 0 \\
\hline Moderate.................. & 41 & 24 & 7 & 7 & 0 & 0 \\
\hline Light ..................... & 36 & 21 & 22 & 22 & 4 & 18 \\
\hline None & 5 & 3 & 70 & 70 & 18 & 82 \\
\hline Totals....................... & 166 & 100 & 101 & 100 & 22 & 100 \\
\hline
\end{tabular}

* As classified, "serious" work was rabbit attack which would kill or conspiculously maiform the plant. "Moderate" work could not be classed as light, but was hardly serious. "Light" work was inconsequential.

The prickly pears over considerable areas may be consumed in extreme seasons. Ordinarily some individual prickly pears, apparently as attractive as others (Plate $6, \mathrm{~B}$ ), are passed by, for what reason we do not know. The flesh of prickly pear pads is to our taste about as palatable as spinach. 


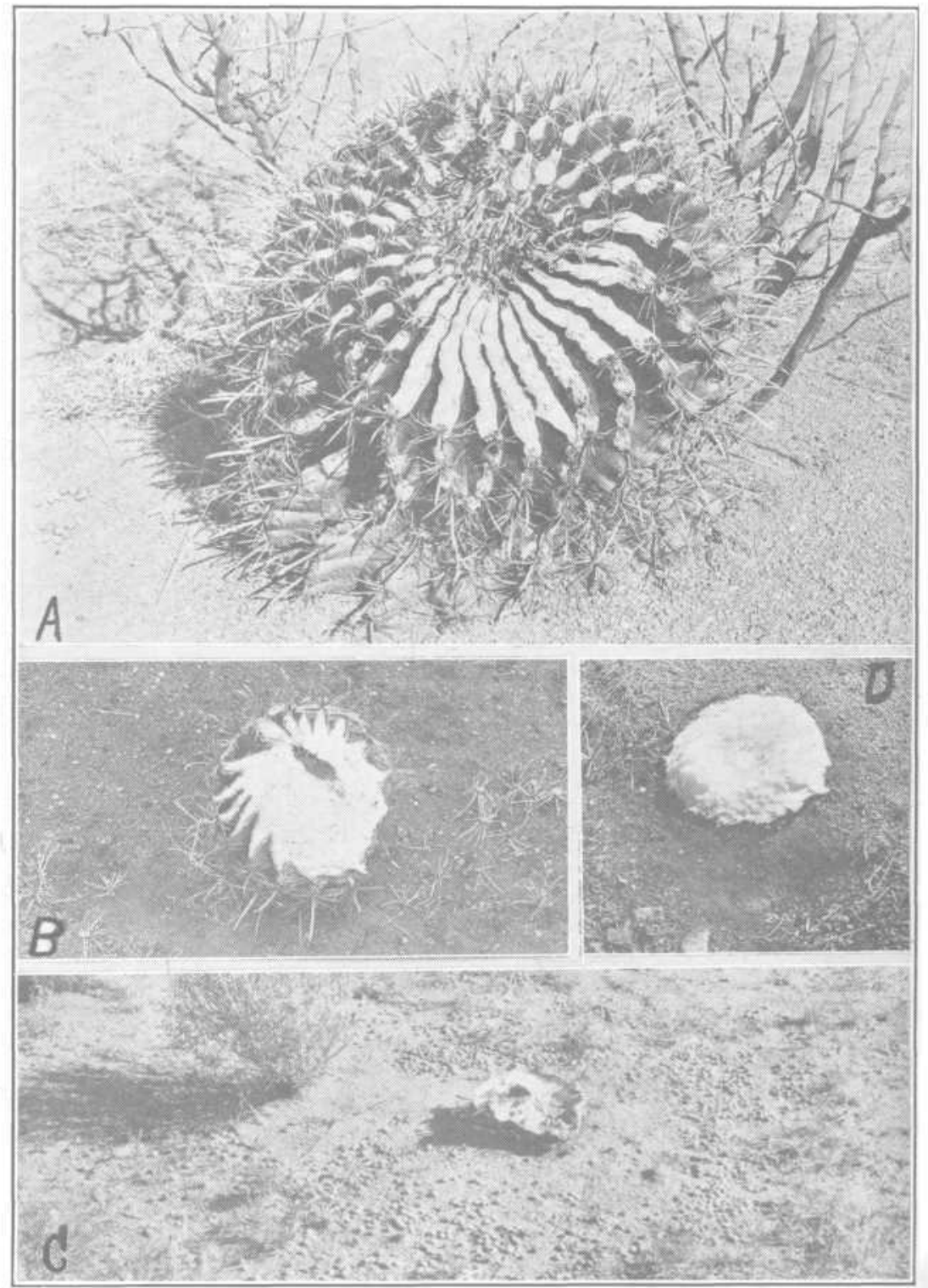

Plate 9.-Stages in consumption of barrel cactus, or visnaga, by jack rabbits, Santa Rita Range; A, The beginning. This specimen is now open to further attack; B, The top gone. Note the spine clusters on the ground, cut off by the rabbits; C, This specimen has been almost wholly transformed into rabbit pellets; D, Nothing left but the base, close to ground level. 
The prickly pear pads are most often caten from the edge, or, where the spines are scattered or worn off, they may be attacked on their fiat sides. Entire joints are frequently consumed. and in very dry seasons the entire plant may be eaten down to the base. Sometimes the cactus is able to put forth new stems, but not infrequently it is killed.

In the vicinity of Tucson a cholla, Opuntur spinosior (Plate 8) is second choice after the prickly pears, thotgh there is perhaps a question as to whether the visnaga, Echinocactus axislizenii, may not belong here. for visnagas are occasionally found heavily eaten by jack rabbits. Once the armature of an Echinocactus is penetrated, the rabbits eat it with avidity, often consuming it nearly to the ground surface (Plate 9). The scattered spines, rabbit tracks on all sides of the cactus, and peliet accumulations clearly indicate the jack rabbit, even if it be not observed in the act.

In eating cholla or visnaga the hare cuts around the spine patches and allows them to fall to the ground. With its sensitive nose it feels about the cactus very carefully, prospecting for a good place to bite in. The nose is carefuily pushed between the spine pads and a hold on the desirable morsel secured. The rabbit often has to puil quite hard to dislodge the piece it is after. The bark may be gnawed to a height of 27 inches. Occasionally one sees joints of this cactus stripped (Plate 8, B). Rarely branches are cut off. Rabbits frequently get stuck with cactus spines, and their movements, as they nurse or shake their forepaws to remove the spines, are comical to say the least.

The ultra-spiny chollas, as, for example, Opuntia fulgida, receive less attention than the others, although on occasion one sees antelope jack rabbits feeding on this species and even resting beneath it.

The buds and flowers of Echinocereus fendleri are sometimes consumed (Plate 10, A). Young sahuaros (Carnegia gigantea) are sometimes eaten near the ground down to the central woody stem.

\section{DISTRIBUTION OF CACTUS}

When considerable numbers of sabbits, and the inevitability of their work on cactus in dry periods, are noted, the probability that the animals affect the occurrence and distribution of cactus on our ranges may be readily understood. In an indirect manner the rabbit greatly favors the cholla although it attacks it somewhat, because pressure is exerted more heavily on the competitors of cholla (grasses and prickly pear) than on the cholla itself. Anything that weakens the grasses tends to favor establishment and growth of new chollas. If this hypothesis holds, cholla, wherever it is spreading in the range country, is an indicator of disturbance and really of overgrazing. To the extent that the rabbit 
helps cholla, it is somewhat inimical to man's interest, for the cholla is becoming a pest on considerable areas in southern Arizona. So far as known jack rabbits do not spread chollas or other cacti directly, as do cattie and possibly wood tats.

\section{DROUTH AND OVERGR A.ZING CRITICAL}

Two factors are of major importance in telation to jack rabbit work on cactus and other vegetation.

First. when too many livestock are permitted on an area, attacks by both stock and rabbits on all palatable vegetation are inevitably more serious and severe.

A second factor influencing the relation of jack rabbits to vegetation is the obvious one of drouth. A few weeks at the driest period of the year may be more significant for the future of the vegetation than all the rest of the year. Similarly the activities of jack rabbits at the climax of a long drouth may be more far-reaching than through many years of less extreme weather conditions. In southern Arizona the seasons of 1917-1918, 1922-1923, and 1924-1925 were especially dry.

It is recalled that 'Thornber's cactus planting experiments (Thornber, 1911, pp. 491-493) were much interfered with and some of then were absolute failures because of the work of jack rabbits at dry periods.

In the early years of the Santa Rita Range, i.e., between 1905 and 1910. Griffiths planted a considerable number of prickly pears. These cacti, while suffering some losses at intervals, were still for the most part in flourishing condition after 20 years. In the drouth of 1924 1925, however, all were killed. Cattle had a part in this, of course, but jack rabbits were probably chiefly responsible.

The influence of jack rabbits on the occurrence and distribution of cactus, as well as of grass and other plants, is therefore related in a rather definite and intinate way to the amount of grazing and the severity of the ever-recurring dry seasons.

Where climatic conditions somewhat handicap the prickly pear the jack rabbit is an important check. It seems obvious, as pointed out by Griffiths (1928, p. 9) that west of the Pecos River. Texas, the growth of prickly pear in comparatively slow, owing to the lack of both fertility and moisture. Similar conditions prevail through much of the arid Southwest. In places more favorable to the pear this animal apparently has little inftuence. It occurs very commonly in sotuthern Texas - but the prickly peat and mesquite have taken much of the country.

The jack rabbit should not be introduced into Australia, India, or Africa in the hope that it will control prickly pear! 


\section{SPINES AS A PROTECTION TO DESERT PLANTS}

While spines have been considered to afford protection against animals to the plants of arid lands, our observations indicate there are distinct limits on their protective powers. It is true that spineless cacti are rarely, if ever, found on the open ranges, but are restricted to well protected sites on steep canyon walls where cattle cannot, and jack rabbits do not, ordinarily go. while the extremely spiny cacti, as Opuntia fulgida, and most visnagas are protected by their spiny armature from attack.

In spite of their spines, however, the prickly pears are regularly attacked and in dry times consumed by rabbits, wood rats, and cattle. Opuntia spinosior is also attacked, though to a much less extent. Even the visnaga and the "jumping" cholla (Opuntia fulgida) are not immune. Of themselves, spines are evidently insufficient to afford complete protection to the plants of arid lands. The character of the spines, the kinds and numbers of animals, and especially, the dryness of the seasons, all infuence the results. We derive the impression that the spines are not so much essential organs produced by natural selection for the protection of desert plants as they are the structural results of the pressure of certain climatic conditions, especially dryness, on the vegetation, and that such protective influence as they may possess is incidental.

\section{JACK RABBITS AND GRASS}

\section{IEPL'S HLI ENI}

Among grasses found in stomachs of Lchus alleni are: Aristida sp., Boutelou, two species, Eragrostis sp.. Trichloris mendocina, Valoto saccharata, Panicum sp., Bonteloua aristidoides, Cenchrus sp., Sporobolus sp., Eriochloa acuminata, Agrostis sp., Chaetochloa sp., Echinochloa sp., and Chloris sp., or 13 genera and at least 14 species. TVe have no concrete evidence of any jack rabbit eating Heteropogon contortus, Andropogon, or the large Hilarias. Mesquite grass (Hilaria cenchroides) does not appear in the stomach analyses though the rabbits undoubtedly eat it. There is little doubt that the jack rabbit feeds on nearly all the species in their strcculent stages.

Jack rabbits are hungry animals and their digestive powers are rapid and efficient. They feed almost continuously, and literally for hours at a time. Grasses palatable to cattle seem to be equally palatable to jack rabbits. These hares - at least under present conditions, where the range is often overgrazed - are possibly harder on the range than the cattie are, as they can graze more closely than cattle. Jack rabbits could, but seldom do, penetrate under bushes and crop off the grasses that cattle cannot reach. 
There is little question that jack rabbits cut off and waste a good deal of grass. This grass-cutting habit has been observed by the authors and by Aldous. In Plot 1A, Santa Rita Range, we often note large patches of dry grass which have been cut, many stalks left lying, and almost none standing. The presence, in every instance of cutting, of the large and unmistakable pellets of jack rabbits indicates that these anumals are in large part responsible.

On April 12, 1923. it was noted that jack rabbits had cut off nearly all the tall grasses in the afternoon shade of certain of the bushes. Abbey (1909, p 95) has referred to the habit of Lepus timidus cutting and clearing away large open spaces to allow them more room to play

\section{LEPUS CALIFORNICUS}

Grasses identified in the stomachs of califormicus inciude the following: Agrostis sp, Aristida sp., Bouteloua aristidoides, Bouteloua eriopoda, Bouteloua sp., Trichloris mendocina, Panicum sp., Hilaria sp, FesIuca, Eriochloa acuminata, Valota saccharata, Chaetochloa sp, Eragrostis sp., and Sporobolus fle.ruosus For this lot of stomachs the diagrams show that about a quarter of all food taken was grass Since fewer stomachs of californcus than of alleni were secured we do not have an adeqtate basis for comparison of food habits As pointed out by Aldous, who has worked principally on californicus, estimating jack rabbit injury to grass by stomach examinations alone is misleading, for the grass wasted should be given attention as well as that consumed. As with the antelope jack, this species bites down many of the tall grass shoots, eats the lower succulent portion, and leaves the upper 80 percent of the stem lying on the ground. The cut stalks may not be available as food for stock.

The graph (Figure 3), while it indicates the importance of grass in the diet of the Arizona jack rabbit, stuggests that for this species grass is not so important as for the antelope jack rabbit. This finding accords with our observation of the distribution of the two species of jack rabbits. While the antelope jack rabbit is the principal hare on the grassy bahadas of the Santa Rita and Baboqtivari ranges and in similar localities, the Arizona jack rabbit is more common in the semi-desert areas where grasses are scarce, and weeds and browse more in evidence.

\section{GENERAL FEFECTS}

Table 11 shows the possible amounts of the different major items of vegetation, including grass, mesquite, and miscellaneous vegetation, consumed by jack rabbits, if our estimates as to weight of food consumed 


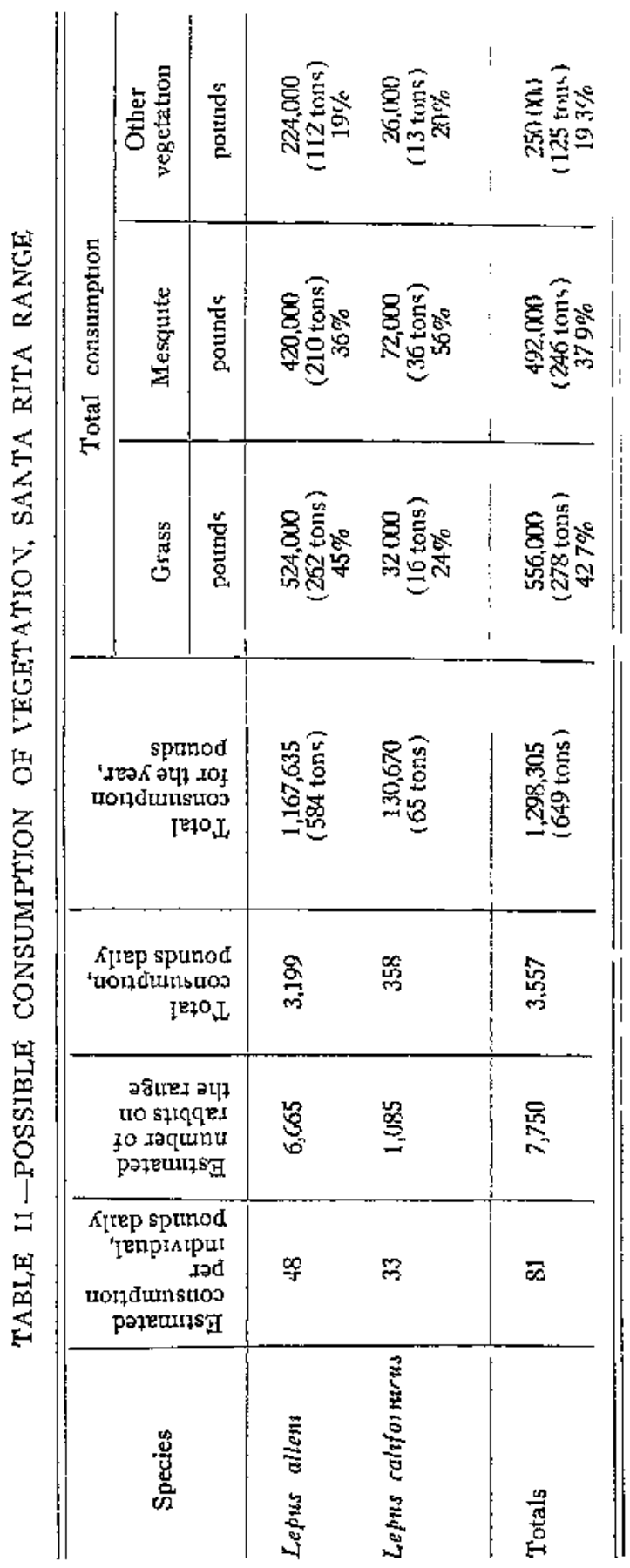


by individuals daily and numbers of the animals present (see p. 559) on the Santa Rita Range are approximately correct. The figures given do not afford any indication of the amount of grass cut and left lying uneaten.

Hensel (umpublished MS, 1919) estimated the average total forage productivity of the Range at 1,100 potnds per acre per year, one-half of which was counted as available to stock under conditions that would not result in overgrazing. At this rate ( 550 pounds per acre per year), probably not excessive for the Range under conservative management, the anount of production for the entire area would approximate $27,-$ 500,000 pounds, or 13,750 tons per year. The calculated amount of this potential product consumed by jack rabbits, including both grass and veeds, is 402 tons, or 2.9 percent. As estimated by Hensel, forage production on the Range includes chieky or principally grass. If the weeds are omitted and only the grass portion of the rabbit's food is compared with potential grass production on the Range, the amotnt eaten by rabbits is reduced to slightly more than 2 percent.

It will be recalled that our determinations (see p. 516) indicate that on the average 30 indivicluals of californicus will eat as much valuable forage as one sheep, and 148 as much as one cow; and that 15 alleni will eat as much valuable forage as one sheep, and 74 as much as one cow.

When added to conservative grazing by cattle the pressure of jack tabbit grazing may at times be enough to produce a condition of overgrazing. The heavier the grazing by livestock the nore opportunity there is for jack rabbit grazing to be harmful. Consequently the mote conservatively a pasture is grazed the less serious is the damage by jack rabbits likely to be.

A long-continued drouth may result in overgrazing by stock and jack rabbits even when under all ordinary conditions the grazing pressure wotld not be too great. These considerations emphasize the necessity for stocking the ranges according to the poor seasons, rather than the best season or even the average season. Forsling $(1924$, p. 5$)$, directly advocates liniting breeding cattle to range capacity in poor years.

Under all but the most conservative stocking with cattle the tendency of grazing by jack rabbits will be to accentuate overgrazing, to eliminate the more palatable grasses and favor their replacement by somewhat less desirable species and by weeds.

Matthams (1921, pp. 234-235) points ott that in Australia rabbits assist the weeds to survive and displace the nutritious grasses. $\mathrm{He}$ says areas about rabbit warrens are often seen upon which weeds are abundant, and that many instances can be cited where, when rabbits 
and stock have been excluded from such areas, the natural grasses have in a great measure displaced the noxious weeds. "Where the natural grasses grow more quickly and luxuriantly than the weeds, the latter are handicapped in their struggle to survive, and where the growth of pasture is retarded and the constitution of the plant weakened by rabbits the weeds are assisted to a corresponding degree."

\section{JACK RABBITS AND WEEDS}

The variety, but not a completc list. of weeds consumed by jack rabbits is indicated by the stomach analy ses. A small amount of additional evidence has been derived from direct observation. Thus the rare Carlozerightia linearifolia, though never identified in rabbit stomachs, is nevertheless so heavily grazed by rabbits that its survival is doubtful in areas where the animals are numerous. On the Jornada Range, snakeweed (Gutierresia juncea) is clipped and perhaps eaten to a slight extent. Ephedra trifurca is also eaten on the Jornada, and occasionally the plants are stripped of all foliage in reach. Petals of Psilostrophe tagetinae have been found in rabbit stomachs, and Fiogonum anmum is known to be eaten. Eschscholt sia Mexicana is freely consumed whenever it is available. When the showy Kallstroemia grandifiora appears the rabbits eat it to a certain extent also. Rarely jack rabbits chew on burroweed (Isocoma coronopifolia), a common and very troublesome poison plant on the Santa Rita Range.

The animals are known to feed extensively on filaree in some places. In other localities jack rabbits are well known to eat a variety of weeds. Two specimens taken near Beswick, California, by Gaut and Ferry, September, 1905, had masticated a mass of the yellow tops and dark frosted lower leaves of rabbit brish (Chrvsothamnus occidentalis). Bailey (October 15,1888 ) found rabbits eating seeds and probably leaves of pigweed (Chenopodium) near Ogden, Utah. Near Voltage, Oregon, in the summer of 1920 , the same observer recorded rabbits feeding on a variety of vegetation including tules, salt grass, bunchgrass, three or more kinds of pigweed, greasebrush, Grayia sp., Tetradymia sp., and Chrysothamnus sp.

Apparently rabbits can make use of many different species of weeds, but only do so, ordinarily, when succulent grass is lacking. The most important effects of jack rabbits on weeds, as on browse, are probably indirect. Though the animais work directly on weeds their destruction of grass must relieve the seedling weeds of much competition. There is littld question that jack rabbit work, at least under conditions of overgrazing, is on the whole favorable to weed growth (Plate 12). 


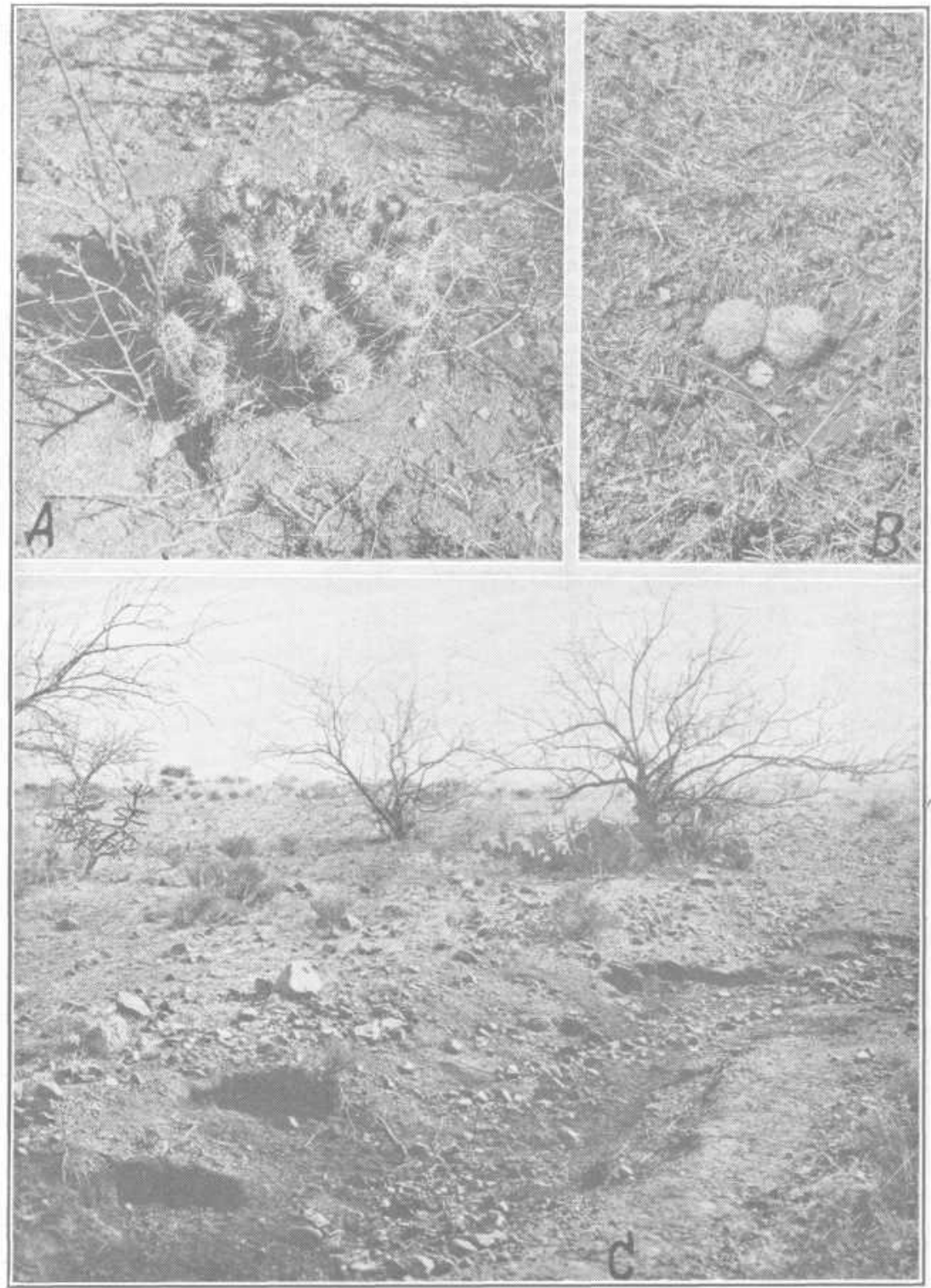

Plate $10 .-\mathrm{A}, \mathrm{B}$, Lesser species of cactus eaten by jack rabbits, Santa Rita Range; A, Hedgehog cactus (Echinocereus fendleri). The round white scars indicate where flowers or buds have been eaten; B, Pincushion cactus (Mammillaria sp.), from which one entire portion has been eaten, the white stump remaining; C, A "lick" on the Santa Rita Range, where jack rabbits have dug and gnawed dark red earth. 
On the basis of extensive observations of regetation in the arid Southwest as related to the influences surrounding it, Cooperrider is of the opinion that the order of rabbit preference for plants, when available. is annuals and then perennials followed by grass.

This observation accords with our own findings that jack rabbits are more abundant in areas where weeds are common than in those where climax stands of grass occur. It is entirely possible that our stomach analyses are not really numerous enough to show true conditions, aside from the difficulty of identifying the small succulent anmuals in the stomachs. It may well be that we have over-emphinsized the rabbit's liking for grass.

\section{JACK R.ABPITS AND CROPS}

The jack rabbit is extremely fond of altalfa. young cotton plants. young grape vines, lawn grasses, and ornamentals. This phase of the food habits of the animal will be more fully treated under economic relations.

\section{ANIMAI FOOD}

Goldnan gives reports by natives in the vicinity of Camargo, Tamat1lipas, January 4-29, 1902, that Lepus califormicus morriami in that vicinity sometimes fecl on the carcasses of dead horses. An American resident assured him that in Lafayette Cotnty. Texas. they were known as horse rabbits on account of this habit.

Insect remains occtr infrequently in rabbit stomachs. Only 3 out of 61 stomachs of $L$. californicus showed insect or other Arthropod material, while only 20 of 179 stomachs of L. alleni contained traces of Arthropods. Apparently all insect material found in the stomachs was of an accidental character.

\section{MINERAL ELEMENTS}

While no notable jack rabbit concentration has been observed abont salt put out for cattle, our observations and those of Aldous indicate that salt or some other mineral element is frequently sought.

At the United States Rabbit Experiment Station, Fontana, California, a spool of salt and sulfur is regularly hung in the cages in which domestic rabbits are kept. The rabbits lick or even eat this material. Rabbits have been found to consume more food which has been salted than food that has not. A rabbit consumes more salt when molting than at other times. It is likely that wild hares must also secure a certain amount of mineral matter for the maintenance of their health. 
Elliot and Crichton (1926) have shown that high mineral content of pasture grass is associated $w$ ith high nutritive value for livestock Not only that, but these authors and also Godden (1926) have pointed out that deficiencies in mineral elements in pasture grasses are associated with specific nutritional diseases.

For several years we have observed a rabbit "lick" on the southwest slope of one of the red lills north of Plot lA on the Santa Rita Range (Plate 10, C). Rabbits, mostly allewi, are numerous in this neighborhood. The animals have dug or bitten into the dark red earth, and fecal pellets are abundant. Analysis of the soil of this "lick" has not show nany salt or saline constittents. Many rabbit pellets found nearby are so coated with red earth as to resemble little red balls of mud. Breaking the pellet shows that the red earth is a surface coating over the remains of vegetation normally present. Rabbit pellets, similarly coated with red earth, have been observed west of Benson, Arizona, and southwest of Vail, Arizona. Jack rabbits have recently (1932) dug holes a foot deep in one of the corrals on the Santa Rita Range and have several times been observed eating the earth from the steep sides of these excavations That salt blocks had lain at these places seemed an obvious conclusion, but analysis of the soil showed only a slight trace of salt; less, in fact, than is contained in the well water supplying the city of Tucson

Gravel or sand was recorded in 26 out of 61 stomachs of californicus and in 97 ont of 179 of alleni. The material was found in stomachs collected from April to October. In some of the stomachs the records were not complete, so that more stomachs rather than fewer actually contained this material.

\section{FEEDING}

The jack rabbit feeds at night, before and after sunrise, and for several hours of the morning, say up to 8 or 10 o'clock. Toward evening they begin to feed at from 4 to 6 o'clock, depending on the time of year. On cloudy days, rarely otherwise, they feed during midday hours. Jack rabbit stomachs examined were never empty, no matter what time they were taken.

The ratio of the weight of stomach contents of the antelope jack rabbit to weight of animal is low, ranging from 0.7 percent to 3.5 percent, and averaging 1.7 percent.

Food seems to traverse the alimentary tract very rapidly. When a small rabbit in our cages ate Bouteloua aristidoides, dry, its feces were larger and light brown, like most of the pellets observed on the range, 
and averaged 7 to $9 \mathrm{~mm}$. in diameter. When feeding on green alfalfa the feces were small, almost black, and averaged 6 to $7 \mathrm{~mm}$. in diameter. After contintous feeding with alfalfa, the rabbit was fed Boutelous at $6-7 \mathrm{pm}$. "Bouteloua" feces were numerous twelve hours later.

\section{ENEMIES}

To what extent can the natural enemies of jack rabbits be relied on to hold the animals in check? We shall now discuss these enemies and their possibilities.

\section{COYOTE}

\section{GENERAL RELATIONS}

Coyotes, the most widely distributed of the flesh-eaters in jack rabbit territory, have long been recognized as enemies of these ofttimes troublesome animals. The first adequate discussion of the interrelations of coyotes and rabbits was given by Palmer (1897, p. 45), who pointed out that the coyote is a most effective rabbit destroyer and accomplishes more good in this way than it ustally receives credit for. $\mathrm{He}$ also mentions the California coyote bounty law, in effect from March 31, 1891 to September 30, 1892. Following the destruction of scores of thousands of coyotes, rabbit increase was so great that shortly, in at least one county (San Bernardino), a bounty of 20 cents apiece was offered on rabbits.

In 1905 (p. 177) Bailey pointed out that on the one hand the coyote kills many sheep and a few goats, some poultry and considerable game, while on the other, the bulk of its food the year around consists of rabbits, prairie dogs, ground squirrels, gophers, wood rats, mice, and small rodents.

Jewett in 1910 asserted that Lepus californicus zvallazeralla in the vicinity of Vale, Oregon, formed the main food supply of the coyote.

Warren (1910, pp. 248-249) has called attention to the fact that coyotes kill many rodents, cottontails, and jack rabbits in Colotado.

Cary's observations in the same State $(1911$, p. 73) offer further evidence of a similar character.

Baker, Korstian, and Fetherolf (1921, p. 310) report that with the destruction of a large number of coyotes, the principal enemy of rabbits in the Wasatch Mountains, Utah, there has been a considerable increase in the number of rabbits and a corresponding increase in damage to conifers. This is an interesting illustration of the fact that predatory mammals quite frequently are friends of the forest. 
Sampson (1928, p. 350) says, "Rabbits, prairie dogs, ground squirrels, gophers, field mice, and chipmunks are staple articles of the coyote diet. ... Organized warfare against the coyote has doubtless resulted in appreciably increasing the rodent population in some localities. However, this disturbance in the balance of nature, as it has been termed, favoring the rodents, is not very serious, as effective methods are also available for holding in check the rodent population." Unfortunately no completely satisfactory method of rabbit control has been devised for the warmer southern part of the western range country, where obviousiy, the difficulty of baiting rabbits is much greater than in the cold northern regions where the snows of winter tend to concentrate the rabbits and make them desperately hungry.

Ligon (192\%, p. 108) notes that the killing of coyotes, badgers, and large prairie-drielling hawks has had a tendency to increase the numbers of the black-tailed jack rabbit in New Mexico.

Will and Emmet Isaacks, cattlemen of Las Cruces, New Mexico, and other ranchers in that vicinity, believe the coyote is an important check on jack rabbits. The rabbits are a real problen, they say, while under present conditions the coyotes do no harm on stock ranches. Forest Service officials and stockmen on the Jornada Range, are unanimously of the opinion that the coyote is a check on the increase of jack rabbits. At present (1930) coyotes are extremely abundant and rabbits noticeably less numerous than usual. Professor J. L. Lantow, Animal Husbandman of the N'ew Mexico College of Agriculture and Mechanic Arts, is "positive" the coyote is an effective check on jack rabbits.

R. L. Moore, manager of the 504,000 acre Waggoner Ranch at Vernon. Texas, believes that coyotes are an important check on rabbits and prairie dogs. Mr. Moore allows no trapping on this extensive property.

Stipervisor Rex King of the Crook National Forest, Arizona, says he has noticed in localities which are the natural habitats of jack rabljits that a drive on coyotes is followed by an increase in rabbits.

A. M. Philipson, U. S. Indian Service, reports that coyotes keep down jack rabbits on the Papago Indian Reservation, southern Arizona.

\section{RABBITS IN COYOTE STOMACHS}

Of 680 stomachs of coyotes taken in the State of Washington (19171919) on which rough records of stomach contents were kept by State and Biological Survey hunters, 85 stomachs, or $12 \mathrm{x} / 2$ percent, contained rabbit (probably including principally $L$. c. zeallawalla, with some $L$. toomsendit townsendii and Sylvilagus nuttallii nuttallii). Tables given by Fenderson (1930, pp. 345, 348) show that out of 36,989 coyote stom- 
achs exanined by Biological Survey huters from 1919 to 1923, 7.029 or 21 percent contained "rabbit" : and of $\$ 9,170$ stomachs examined from 1924 to $1928,12,141$ or 20 percent contained "rabbit."

\section{SEASONAL, CYCLIC.IL, AND LOCAL ASPECTS}

The relation of the jack rabbit to the colote population is subject to marked variation. When rabbits are abundant, coyotes mas secure many, when scatce, few. An estimate of the significance of the conote as a jack rabbit enemy based on stomach examinations during a season of either abnormally large or small numbers of rabbits might therefore be misleading. Under anything like natural conditions coyote-rabbit relations are automatic in character; but the rabbit probably has nore to do with coyote numbers than the coyote does with rabbit numbers.

Trappers in the San Angelo. Texas, region reported to Bailey that the rabbit was rarely found in coyote stomachs in 1918 while the previous year it was generally found. Dixon $(1925, \mathrm{p} .45)$ found that coyotes in northern California showed a high percentage of game and domestic stock eaten. while stomachs from the southern part of the State showed ground sqtirrels and jack rabbits predominating.

Henderson (1930, p. 338) refers to studies of the coyote in Nevada in winter, which showed that rabbits were its principal food. With disappearance of the snow, however, the coyote had greater difficulty in catching rabbits, and turned to herds of domestic sheep.

\section{CHECK AND B.ALANCE RELATIONS}

"An unusual increase of jack rabbits in any region is always followed by a corresponding influx of coyotes," says Bailey (1905, p. 17 $)$. "which probably accounts in part for the often-observed fact that in the years following their maximum abundance jack rabbits are unusually scarce."

Nelson (1918, p. 424) after referring to efforts of the Federal Government to suppress coyotes, says, "The complete destruction of coyotes would, no doubt, upset the balance of nature in favor of rabbits, prairie dogs, and other harmful rodents, and thus result in a very serious increase in the destruction of crops."

Evidence on increase of jack rabbits following coyote eradication is conflicting. Most of it is uncritical, and the best leaves much to be desirec. There are reports, particularly from Texas and Utah, that rabbits and rodents have not increased following eradication of coyotes and other flesh-eaters. There is so much competent testimony, however, that jack rabbits often do increase following coyote etadication that it cannot be lightly dismissed. Of course other factors entirely aside 
from predators, as favorable or unfavorable climatic conditions, or presence or absence of disease (see p. 553) may play a part in the observed variation in numbers of jack rabbits.

There is a feeling on the part of many officials directly concerned with rodent control, and also among some stockmen, that the activities of coyotes and other carnivores in controlling jack rabbits and rodents are negligible. It is felt by the writers, however, that the flesh-eaters undoubtedly help to regulate jack rabbit numbers. We agree with $\mathrm{Gil-}$ christ that while "A few individual coyotes will kill calves, as a general thing the presence of coyotes on a cow range infested with jack rabbits or kangaroo rats is to be encouraged. The wholesale poisoning of conotes and bobcats on cow ranges in the jack rabbit or kangaroo rat country is to be avoided." (Mimeographed news letter to hunters, A tizona, March 10, 1930.)

\section{BOBCAT}

Rabbits constitute one of the principal items in the diet of the bobcat. One of these animals shot on the Santa Rita Range had its stomach completely filled with rabbit remains.

Bailey (1905, p. 171) writing of Lynz baileyi in Presidio County, Texas, refers to the ranchmen's complaints of some poultry being killed, and still worse, a few sheep. It also takes a few quail and other birds. But there is an even larger sum on the credit side of the account. For example, bobcat feasts in the rocky comers of the cliffs usually disclosed a great preponderance of rabbits and wood rats. Long-continued field studies of bobcats in Texas convinced Bailey that the benefits conferred by the animal in consuming not only rabbits but rodents of other kinds outweighed darnage done.

The testimony of other observers is neariy unanimous to the effect that the bobcat preys consistently on rabbits. Thus Warren (1910, p. 254) says that in Colorado bobcats feed on rabbits, wood rats, mice, and birds. Cary (1911, pp. 167-168) writing from the same State. says that bobcats prey much on rabbits and other small mammals. Locally, he says, they are probably to be considered useful animals although they commit seriots depredations to poultry and sheep.

\section{SNAKES}

In the mesquite country on Ash Flat in the Graham Mountains, Arizona, May 30, 1914, E. G. Holt found a rattlesnake making a meal of several very young rabbits. Seton (1929, p. 752 ) reports the builsuake and the rattler as important enemies of the jack rabbits. 
Culley once killed a large rattler on the Santa Rita Range in the act of swallowing a young jack rabbit as large as a cottontail. When found the snake had the rabbit all down but the hind feet.

On May 1, 1931, O. N. Arrington of Tucson reported that he collected a rattlesnake (Crotalus atrot) measuring 42 inches without the rattles, and with a gross weight of 2 pounds, 13 ounces. On dissection two jack rabbits were found in the snakes stomach, a small baby jack and a larger jack. The snake's stomach was $233 \%$ inches long. The smaller animal occupied $5 \mathrm{~s} / 2$ to 6 inches of the space and the other approximately 18 inches. Together the jack rabbits weighed 1 pound, 3 ounces; snake carcass, 1 pound, 10 ounces.

\section{BIRDS}

Almost all of the larger birds of prey feed on jack rabbits. Palmer (1897, p. 44) and Lantz (1908, p. 336) have published detailed lists of the bird enemies of rabbits.

That the golden eagle, great horned owl, western red-tail, ferruginous rough-leg, and bald eagle feed extensively on rabbits is attested by stomachs and pellets examined by the Biological Survey, and bones found on or near nests. Sometimes an untusual accumulation of material was discovered at predator nests. In the Davis Mountains, Texas, Bailey found remains of at least 100 cottontails, together with a few young jack rabbits, in the debris about a horned owl's nest. It is not improbable that young jack rabbits are more frequently taken than the older ones. One observer near Albuquerque, New Mexico, saw a ferruginous rough-leg kill a jack rabbit.

An increase in jack rabbits following killing of their natural enemies, the hawks, is mentioned by Ligon. He reports that in the Pecos Valley, New Mexico, in 1918 there seemed to be few natural enemies of rabbits, which were extremely abundant, so numerous in fact, that they were killed and shipped to market as a commercial proposition. Ligon (1927, pp. 58-59) makes a strong plea for the hawks and owls. especially the red-tail, rough-leg, and Swainson, as destroyers of rabbits. prairie dogs, and other injurious rodents.

Golden eagles have been found feeding on antelope jack rabbits on the Santa Rita Range. We have examined many nests of western redtails and western horned owls on the Santa Rita Range but have failed to find any jack rabbit remains, although parts of cottontails and smaller rodents were plentiful. Jack rabbit bones together with fragments of cottontails, wood rats, meadow mice, and pocket gophers were found in owl castings under a large pine tree near Flagstaff, Arizona. 


\section{MISCELIANEOUS}

Among other enemies of jack rabbits in the Southwest are gray foxes (Bailey, 1905, p. 181; Warren, 1910, p. 236) ; badgers (Palmer, 1897, p. +4); man, especially the aborigines and some of the Mexican population, as well as farmers, irresponsible shooters, and sometimes hunters for the market; the automobile, forest fires, drouth, hail, and extremely cold weather.

\section{CONCLUDING REMARKS ON ENEMIES}

The extent to which natural enemies of jack rabbits can be relied upon to hold these animals in check is an ever-recurring and fertile subject of discussion. Admittedly the extent to which natural enemies prey upon them, and the practicability of reiying upon predators for satisfactory control of jack rabbit abundance, are dependent upon local conditions, including the type of crop and livestock production prevailing in the region.

Under present conditions in Arizona the predators which feed upon jack rabbits to an extent that renders them a factor which should have consideration in a program of wild-life administration would include the coyote, bobcat, gray fox, the bull snake, and rattlers, some of the larger hawks and owls, and the eagles. The problems involved in control of jack rabbit populations by natural enemies are exceedingly intricate and their solution is rendered particularly difficult becatse of the well-known tendency of these animals to fluctuate greatly in numbers, evidentily due to the operation of a variety of causes which up to the present time have not been subjected to adequate critical investigation. Interpretations offered of observations made in many localities and by interested individuals have varied widely in conclusions reached. Commonly conclusions announced are clearly modified by the viewpoint of the individual, the extent to which there has been opportunity for long-time and comprehensive accumulation of facts and a disposition to weigh carefully the various factors that may have been operative. Manifestly snap judgment cannot be relied upon to provide a satisfactory solution of these varied and important telationships. Based on their field studies the authors of the present paper would emphasize the need for intensive study of this problem in order that comprehensive data may be accumulated and careful evaluation made of the im. portance of the various factors involved as a basis for a sound working program in future handling of lands populated by jack rabbits. Fortanately the Biological Survey and its cooperators are now engaged in such a study from which it is hoped that information may be secured and conclusions reached which will prove helpft1 in dealing with this important problem. 


\section{PARASITES AND DISEASES}

\section{ARTHROPODS}

Arthropod parasites of jack rabbits include flies, fleas, possibly sucking lice, and ticks.

The largest and most conspicuous of the insect parasites are the dipterous larvae commonly known as "warbles," related to the ox warble or grub (Hypoderna) which lives in the backs of cattle. Rabbit warbles belong to the genus Cuterebra* (family Oestridae). They are large, dark brown or black, squirnung grubs which live in mucoid cysts in the subcutaneous connective tissties. The surface of the warble is hard, spiny, and feels like a rasp. Since each, while still resident beneath the skin of the jack rabbit, becomes as large as the last joint of a man's muldle finger, one may well imagine the resultant irritation. From one to several may be present in the throat or rump of a single animal. In an extrene case no less than 13 large and 3 young warbles were found in the throat of one antelope jack rabbit. Some years, nearly all of the rabbits are infested; in others, warbles are scarce. A sudden reduction in numbers of these parasites took place in 1927-1928; nor has the infestation appreciably increased up to date (February, 1933).

Since the life history, especially the mode of infestation, of $C$ utercbra, is unknown, some facts which may be significant are worth recording. The adult insects are large, hiack flies which wonld be conspicuous about the jack rabbits if they commonly hovered about them for oviposition: but we have never seen one about its host. Only two specimens of the adult have ever been taken in the field by members of the Department of Entomology of the University of Arizona, and these were neither on nor near jack rabbits.

There is no apparent seasonal periodicity in the occurrence of younger and older larvae. Large, apparently mature warbles are found at any time of year, and young grubs may occur at the same time in an individual host. On two occasions young jack rabhits have been found infested with nearly mature warbles, one of these rabbits weighing only about 3 pounds, the other just above 4 pounds. Since the adult flies probably appear at a definite season, it is unlikely that they oviposit directly on the host; for if they did so there would be an obvious periodicity in the larval stages. The eggs should be conspicuous if placed on the hair of the host, but in handling hundreds of rabbits the eggs have never been

* Cuterebra princeps and C. americana have been determined for us by $\mathrm{Mr}$. F. C. Bishopp, United States Bureau of Entomology. 
found. It has been suggested that the eggs may be placed on vegetation, whence they are ingested by the host animals; a suggestion which our observations support. If this be the method, the actual infestation might occur at any time of year or at several successive times in the same year for a single host.

Only 31 percent of the antelope jack rabbits examined since 1928 have shown Cutcrebra infestation. Of the infestations recorded, 60 percent were in the throat, and 40 percent in the rump. In the Arizona jack rabbit, in the same period, the infestation has been 50 percent, all in the rump. Prior to 1928 throat warbles were undoubtedly more abundant and occurred in californicus as well as in alleni. Whether the throat and ramp are infested by different species of Cuterebra has not been determined. Bailey has observed Cuterebra larvae in the eyes of jack rabbits in Otegon,

Fleas, though reported by some observers to be abundant on jack rabbits, are not common in southern Arizona. In fact, on a number of specimens of both species it was impossible to find fleas. On many others but few were found. For californicus other observers have noted heavier infestations. On the Santa Rita Range in January, 1921, Bailey noted that fleas were found abundantly on jack rabbits, which at times fairly swarmed with them. We have never been able to confirm this. Aldous, in November, 1929, examined 45 jack rabbits on the Jornada Range, finding all infested with fleas; and in January, 1930, he recorded 38 from Mesa, Arizona, as 100 percent infested. One species of flea (Hoplopsyllus affnis) occurs on both jack rabbits, and the cat flea (Ctenacephalides felis) has also been taken from californicus.*

Although careful search has been made, we have found neither sucking lice (Anoplura) nor biting lice (Mallophaga) on jack rabbits. This is not strange, since the literature fails to reveal a single record of occurrence of a biting louse on any species of North American rabbit; and only the following records of Anoplura from wild rabbits in the West. Keilogg and Ferris (1915, p. 28) and Ferris (1916, p. 102) have reported sucking lice (Haemodipsus ventricosus) from L. californicus in Sonoma and Humboldt counties, California, and from L. c. deserticola, Ehrenberg, Arizona. Francis (1922, p. 23) has recorded the same parasite fron jack rabbits in Utah.

The jack rabbits of southern Arizona are commonly infested with ticks. The seasonal distribution of young and adult ticks is so distinct that they were supposed, prior to specific identification, to be different

"Determinations by F. C. Bishopp 
species. All have been identified, however, as Dernacentor parumapertus marginatus The large, engorged adults are found in great numbers on the ears and around the eyes of jack rabbits during the summer months, appearing in May and disappearing in September. or at the latest, October. During June and July nearly every jack rabbit of both species is infested. In late autumn and winter quantities of the young or seed ticks, of the above species are found on the ears and eyes of both jack rabbits, first appearing in October and becoming most abundant in November, December, and January. While an individual host animal may carry a large number of these young ticks, the percentage of jack rabbits infested appears to be less than in summer.

\section{TAPEWORMS AND NEMATODES}

The most conspicuous of several "worms" which parasitize the jack rabbits is a species of tapeworm (Multiceps sp.) which occurs within the rabbit in the "bladder worm" or cysticercus stage, i.e. the rabbit is the secondary or intermediate host. The coyote is probably the primary host. The watery cysts of this parasite may be found at any time of year, occurring in an estimated 10 to 20 percent of the hosts, the degree of infestation showing some variation in different years. These cysts may occur in almost any part of the body. In the muscles they vary from the size of a sparrow egg to that of a man's fist. When of large size they may be evident as distinct swellings on the living animal (Plate 11, A). In two or three instances a bulk of cyst material estimated at nearly a quart occupied the body cavity of the host (Plate 11, B). Several cysts may occur in a single badly infested individual. Two specimens have been taken in which a cyst the size of a small hen's egg was so placed between the jaw muscles on the side of the head as to force the lower jaw to one side, causing the incisor teeth to wear off in a diagonal slant, and distorting the molars so as to render eating difficult or nearly impossible. Both specimens were poos and probably not far from starvation. In one of these the stomach was full of coarse, unchewed grass and weeds.

We have but a single record of a mattrre tapeworm occurring in the jack rabbit. Nichol took a specimen of Raillietina sp. from the small intestine of Lepus alleni.

Small nematodes of two species have been taken from the alimentary canal of the jack rabbit. One of these, Nematodirus sp., is found in the intestine; the other, Dermatoxys veligera, ${ }^{*}$ is rather common in the

* All determinations of netnatodes and tapeworms by the Bureau of Animal Industry, U. S. Department of Agriculture 


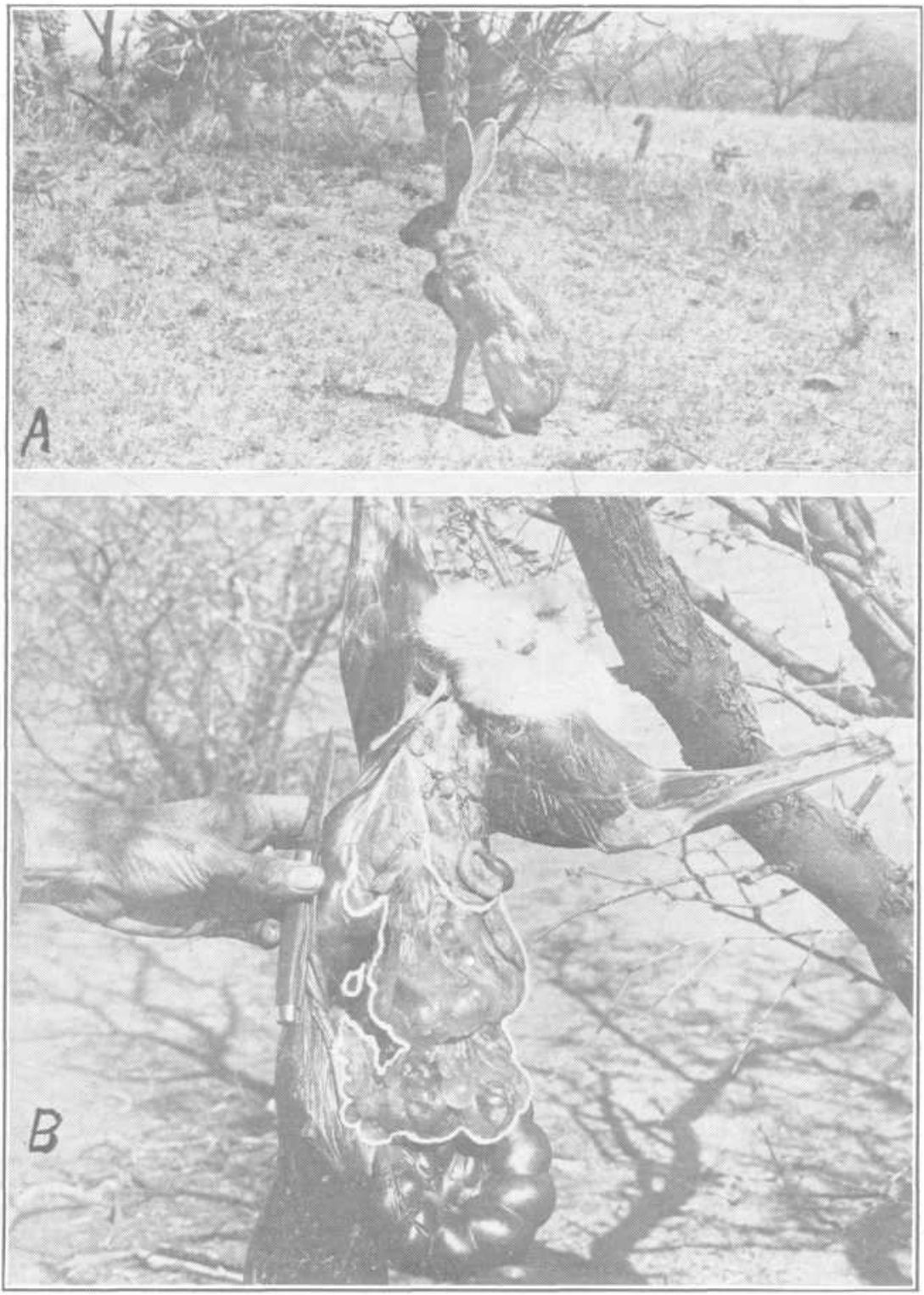

Plate 11.-A, An antelope jack rabbit with tape worm cyst beneath the skin of the throat; B, An unusually large tapeworm cyst in the body cavity of an antelope jack rabbit (cyst material outlined in white). 
coecum. We have observed no instances in which either of these appeared to be of great importance to the host.

In spite of the high incidence of parasitism among our jack rabbits there is little evidence that parasites have affected the numbers of the animals in sotthern Arizona during the past 10 or 12 years. It is reasonable to suppose, however, that in extreme cases weakening of the host occurs, leading perhaps to the capture of the jack rabbit by a coyote or other predator.

Marked fluctuations in numbers of jack rabbits do not occur in the southern Arizona region, nor do we have the extremes of parasitism or of disease that are so conspicuous in some other places. As might be cxpected, extreme infestation with parasites, and serious outbreaks of disease, appear to be definitely correlated with excess population of jack rabbits. 'Thus, Pailey, in eastern Oregon, in the early autumn of 1920 , sketched the following vivid account of conditions among the jack rabbits there.

"At the present time, Augrst and Septemher, the rabbits are dying off rapidly from various diseases. Almost as many dead as alive are seen and many sick individuals are so far gone that they are stupid and may be picked tup by the ears without effort to escape. Many were seen actually dying and watched as they made their last kick, then examined for symptoms.

"Many were heavily infested with Ctterebra and some had both eyes destroyed or so crowded with these parasites as to be unable to see. I watched a Cuterebra larva crawl out of the cornet of the eye of one rabbit as he sat tuncler a sagebrush and the other side of his head was puffed out by several more. Some had bunches over their backs and sides until they were misshapen with them, but $T$ do not know that these alone caused death.

"Some of the rabbits have large bunches of transparent fluid with white specks in it, the tapeworm larval cysts, under the skin and in the body cavities. In heavily infested individuals these were like bunches of white grapes among the intestines, in the thoracic cavity and in the liver and kidneys, apparently enough to kill the rabbit.

"In other rabbits watched in their lest death struggles the symptoms were different and apparently not due to parasites. One had a greatly enlarged heart, filled up with white, hard tissue, congested and spotty liver [this lesion indicates tularemia], congested lungs with many hemorrhagic spots, enlarged and softened kidneys, and dark red muscle. After the first good rain the rabbits scattered out over the higher ground and apparently the mortality decreased." 


\section{TULAREMIA AND OT'HER DISEASES}

Considering the number of jack rabbits which we have examined more or less carefully the percentage of obviously diseased animals found is surprisingly small.

Perhaps the most important disease of jack rabbits, certainly the one of greatest present interest, is tularemia or "rabbit fever," which is infectious, plague-like, and frequently fatal to rodents and rabbits. It is readily transferred to man by ticks and blood-sucking insects, or by personal contact with diseased rabbits. In man it is a debilitating, disabling, and sometimes fatal malady, with a death rate of about 4 percent.

Generally recognized in man as an important disease for scarcely more than a decade (Francis, 1922) tularemia has already been reported in all but three of our states. Although we have not personally encountered any case in rabbits, Hull (1930, p. 210) records two cases of tularemia in man in Arizona.

Obviously the incidence of the disease is less in this region than in some others. Nevertheless, since rabbits and hares constitute the great reservoir of infection in the United States, it seems desirable to sound here a note of warning.

If an epizootic disease breaks out among the rabbits leave them severely alone. Beware always of poor, emaciated, weak, or obviously sick rabbits of any species. If such be killed, the carcass should be burned, buried, or similarly destroyed without handling. Rubber gloves should be used in dressing rabbits if the presence of tularemia is suspected in the locality. The liver and spleen of a rabbit infected with tularemia show small white spots - foci of necrosis, or decay, affording what is perhaps the best evidence of the disease. If an apparently healthy rabbit being dressed or dissected shows evidence of disease at once discard and destroy the specimen and cleanse the hands as thoroughly as possible, using antiseptic if available. The germ of tularemia can infect a human through the unbroken skin. In any case, however healthy the animal may appear, if it is to be eaten it should be thoroughly cooked as a precautionary measure. Even an infected animal is made safe for food by heating sufficiently to cook the flesh clear to the bone. Take no chances on eating rabbit meat "rare." Infection most frequently occurs from direct contact with rabbits. Thus, of 540 human cases listed by Hull (1930, p. 218) 453 had dressed or dissected rabbits. Most of the others had been insect or tick bitten. Ticks and deer flies caused more infections than other insects known to be capable of transmitting the disease. 
Our records of diseased rabbits in Arizona show only a few sporadic occurrences. A californicus female had two large tumors in the vicinity of the shoulders. One was under the skin, with no evternal opening. the other was exuding pus. A male alloni had a large spherical tumor 1 inch in diameter in the spleen. Aldous in 1929 examined 45 callfornicus on the Jornada Range and recorded 2 with "pus boils" and 2 with pylephlebitis (inflammation of the portal vein) A number of cases of infections or ticer-like sores have been noted on the genital organs of both male and female alleni. These sores were inmediately around the genital openings, and produced a swollen vuiva in the female and swollen prepuce in the male. Presumably such infections would be transferable by coitus.

Pus infections of the cavities from which Cufcrebra grubs have issued are common but by no means universal.

Henshaw and Birdseye $(1911$, p. 20) pointed out that in the Bitter Root Valley, Montana, several kinds of rabbits, including Lepus baird, Lepus campestris and Svivilagus nuttalli, carry the ticks which transmit Rocky Mountain spotted fever.

\section{NUMBERS}

\section{FLUCTUATIONS}

Marked fluctuations in rabbit numbers, esfecially in Canada, are well known. Preble (1908), Nelson (1918), Hewitt (1921), Soper (1921), Elton (1927), and others have given strong evidence of cyclic fluctuation in northern climates.

From a position of skepticism as to the marked differences in fluctuations in animal numbers in the north and south we have been forced to conclude that cycles are much harder to trace in the milder climates. Studies of the jack rabbits of southern Arizona have not revealed strongly marked fluctuations. This is not saying, however, that lesser fluctuations do not exist. So far, our counting methods are not refined enough to disclose ninor variations in numbers

Regarding true causes of jack rabbit fluctuations we are still very much in the dark. The classification of causes of cycles made at the Matamek cycle conference calls to mind the vagaries and mysteries cited by the peoples of pre-scientific eras in their flounderings after satisfactory explanations of the insistent natural phenomena all about them. Many of the causes cited are simply suggestions wihch serve as a cloak for ignorance. 


\section{JACK RABBIT COUNTS}

The determination of the numbers of jack rabbits has been one of the most puzzling and troublesome of problems in this study. Yet, since knowledge of numbers is essential if estimates of ecologic or economic status are to mean much in a quantitative way, we have tried several methods and finally arrived at reasonably satisfactory results.

Something, but unfortunately not much, has been learned by tallying up the numbers on definite areas as recorded in connection with rabbit drives.

Jack rabbit censuses by automobile have afforded somewhat better information.

The best counts of all are those in course of which rabbits and cows seen were carefully recorded and their ratio on a particular area determined.

Ligon in 1918 reported that the Pecos Valley, New Mexico, from Fort Sumner southward for some 160 miles into Texas, was perhaps worse infested by jack rabbits and cottontails than any other part of the Southwest. He estimated that rabbits averaged 400 to the square mile (0.62 per acre) over several hundred square miles of the valley. But near Carlsbad Cave in the same valley in 1924 Bailey saw so few jack rabbits that he judged their total numbers would not average more than three per square mile (0.0047 per acre).

In 1929, Aldous poisoned 101 rabbits on $141 / 2$ acres on the Jornada Range, 61 cottontails and 40 jack rabbits (2.7 jack rabbits per acre).

Between 1923 and 1927, principally on the Santa Rita Range, we made more than 50 jack rabbit counts, mostiy at times of year when visibility was best, and ustually from an automobile moving at 10 to 15 miles per hour. The counts thus made covered a lineal distance of 238.4 miles, but the time of day was not recorded for all. Assuming that we had under observation a strip 500 feet wide, the area embraced was approxinately 14,448 actes, on which were recorded 767 rabbits, (34 per section, or 0.053 per acre). At this rate, there would be 2,618 jack rabbits on the 77 square miles of the Range.

We are certain, however, that this is an underestimate. One never sees all the rabbits in a 500-foot strip, because of variable attention of the observer, and low visibility of the rabbits, due to their immobility and to protective regetation.

The most satisfactory of these estimates was that made by counting the rabbits at the time of day when they were visible in greatest numbers. On this basis (90 jack rabbits seen before 6 a.m. and after 6 p.m., 
on a 500 -foot strip 17.9 miles long) there were 53 jack rabbits per section ( 0.083 per acre), or 4,088 on the entire Range. Even this estimate is quite likely below the actual numbers.

Table 12 includes all counts in which time of day was recorded. In all these counts made before 6 a.m. and after 6 p.m., five jack rabbits were seen to the mile; in all counts before 8 a.m., and after 4 p.m., 4.3 per mile; in all counts between 8 a.m. and 4 p.m., 2.3 per mile; while between 10 a.m. and 2 p.m. but 1.5 were noted per mile.

Another method of counting jack rabbits was tested which in our opinion gave the best results obtained. Both jack rabbits and cattle were counted and a ratio established. The approximate number of cattle on the Range being known, an estimate of the total jack rabbit population was made.

TABLE 12,-JACK RABBIT COUNTS ON THE SANTA RITA RANGE (1923-1927).

\begin{tabular}{|c|c|c|c|c|}
\hline 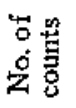 & Time of day & $\begin{array}{c}\text { Total } \\
\text { jack } \\
\text { rablits }\end{array}$ & $\begin{array}{l}\text { Total } \\
\text { of } \\
\text { miles }\end{array}$ & $\begin{array}{c}\text { Jack rabbits } \\
\text { per mile }\end{array}$ \\
\hline 5 & Before 6 a.m., and after 6 p.m...... & 90 & 17.9 & 5.0 \\
\hline 24 & Before 8 a.m. and after 4 p.m........ & 360 & 82.1 & 4.3 \\
\hline 19 & Between 8 a.m. and 4 p.m. ........ & 149 & 63.8 & 2.3 \\
\hline 5 & Between 10 a.m. and 2 p.m. ........ & 24 & 16.3 & 1.5 \\
\hline
\end{tabular}

TABLE 13.-COW-JACK RABBIT COUNTS, SANTA RITA RANGE.

\begin{tabular}{|c|c|c|c|c|c|c|c|c|}
\hline Type & 总 & 总 & 总商 & $\underset{ت}{ت}$ & 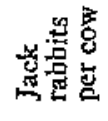 & 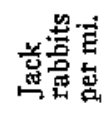 & 总总总 & 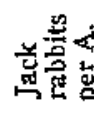 \\
\hline Semidesert............ & 38.9 & 2358 & 207 & 68 & 3.04 & 5.3 & 54 & .085 \\
\hline Mesa & 37.6 & 2280 & 535 & 133 & 4.02 & 14.2 & 149 & .233 \\
\hline Foothill ... & 8.6 & 527 & 50 & 20 & 2.50 & 5.8 & 60 & .095 \\
\hline Count $14 * \ldots . . .$. & 6.0 & 364 & 30 & 25 & 1.20 & 5.0 & 52 & .082 \\
\hline Totals for range & 91.1 & 5529 & 822 & 246 & 3.34 & 9.0 & 95 & .149 \\
\hline
\end{tabular}

* Mesa and foothill types could not be separated in this count. 


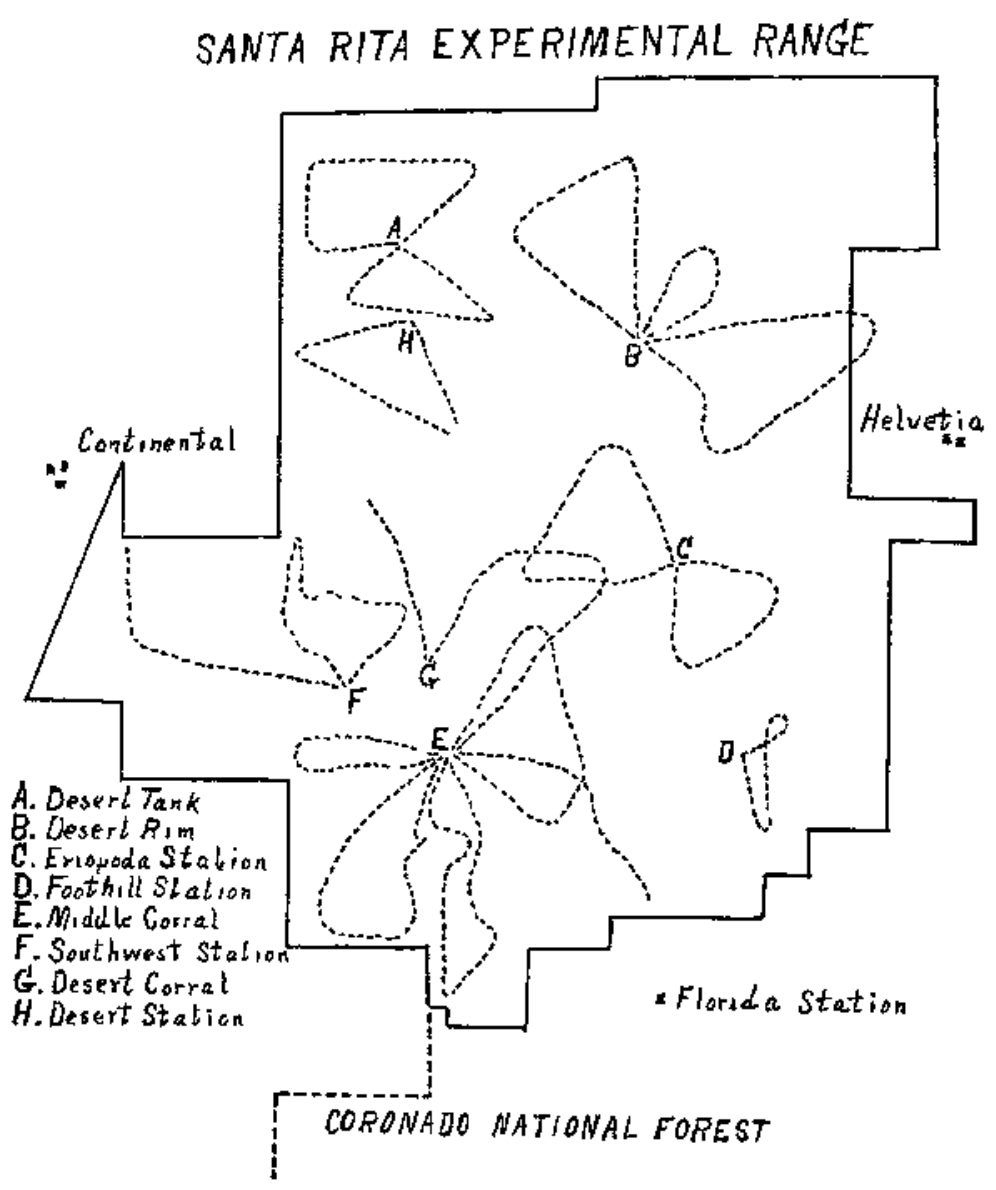

Fig. 4.-Dotted lines show routes traversed in making jack rabbit-cow counts.

In the cow-jack rabbit counts we travelled on horseback, on foot, or by car across a portion of the Range, calculating the distance by the use of a tally checker, and plotting our course on a map. All jack rabbits and all cattle on a strip 500 feet wide and 91.1 miles long were counted (Fig. 4). This is an area of approximately 5,529 acres. Mileage was as follows: by car, 2.5 miles; on horseback, 34.25 miles; on foot, 54.5 miles. Sometimes two observers counted the same strip at the same time. This doubtless enabled them to see more rabbits. Seggregated according to the types in which they were made, the results are shown in Table 13.

There was a marked concentration of jack rabbits in the mesa type, where the rabbits per mile were considerably more numerous than in either the barren semidesert area or in the well-grassed foothill type. 
Multiplying the number of cows, approximately 1,100 , by $3.3+$ (cowjack rabbit ratio) we get 3,674 , the total of jack rabbits. This checks fairly well with the number determined by connts made previously (see Table 12) during those times of day when rabbits were most numerous. Many jack rabbits were doubtless missed on these counts, but it is perhaps safe to assume that we saw half of the rabbits. If this be correct, the true number of jack tabbits on the 77 square miles of the Range would be twice 3,674 or 7,348 . We conclude that the permanent poptlation of jack rabbits on the Santa Rita Range probably does not exceed 10,000 and may not be over half that.

Segregating jack rabbits by species (see Table 14), we find a notable difference in the distribution of Lepus allesi and $L$. californicus by vegetation types. There appear to be $2.85 \mathrm{~L}$. alleni to each $\mathrm{L}$. califor nicus in the semidesert type, 5 alleni to each californicus in the foothill type, and 11.35 alleni to each califorricus in the mesa type.

Lepus alleni is apparently least abundant, on an acreage basis, in the semidesert type (0.062 per acre); it is only slightly more abundant in the foothill type (0.075 per acre) ; but in the mesa type it is approximately three times as abundant (0.214 per acre) as in either of the others.

With Lepus californicus the situation is different. This species seems to decrease quite regularly from the semidesert type, where it is most abundant $(0.022$ per acre), through the mesa type where it occurs at the rate of 0.018 per acre, to the foothill type, where it is 0.015 per acre.

\section{PELLET COUN'TS}

In captivity rabbits regularly defecate while they are feeding or very soon after. Field observations indicate similar babits on the part of hares in the wild. The utility of the pellet count depends in part on this observed relationship between feeding and defecation. There is a significant relationship between numbers of pellets and abundance of jack rabbits on a given area. Though it gives no information on absolute numbers, the pellet count is a reliable method of determining relative abundance.

The question has been raised, with reference to our experimental plots, whether there is not an abnormal concentration of rabbits in the cattle exclosures, where grass is sometimes more abundant than outside, and into which rabbits may range freely. The most convenient way of checking this point is the pellet count. 


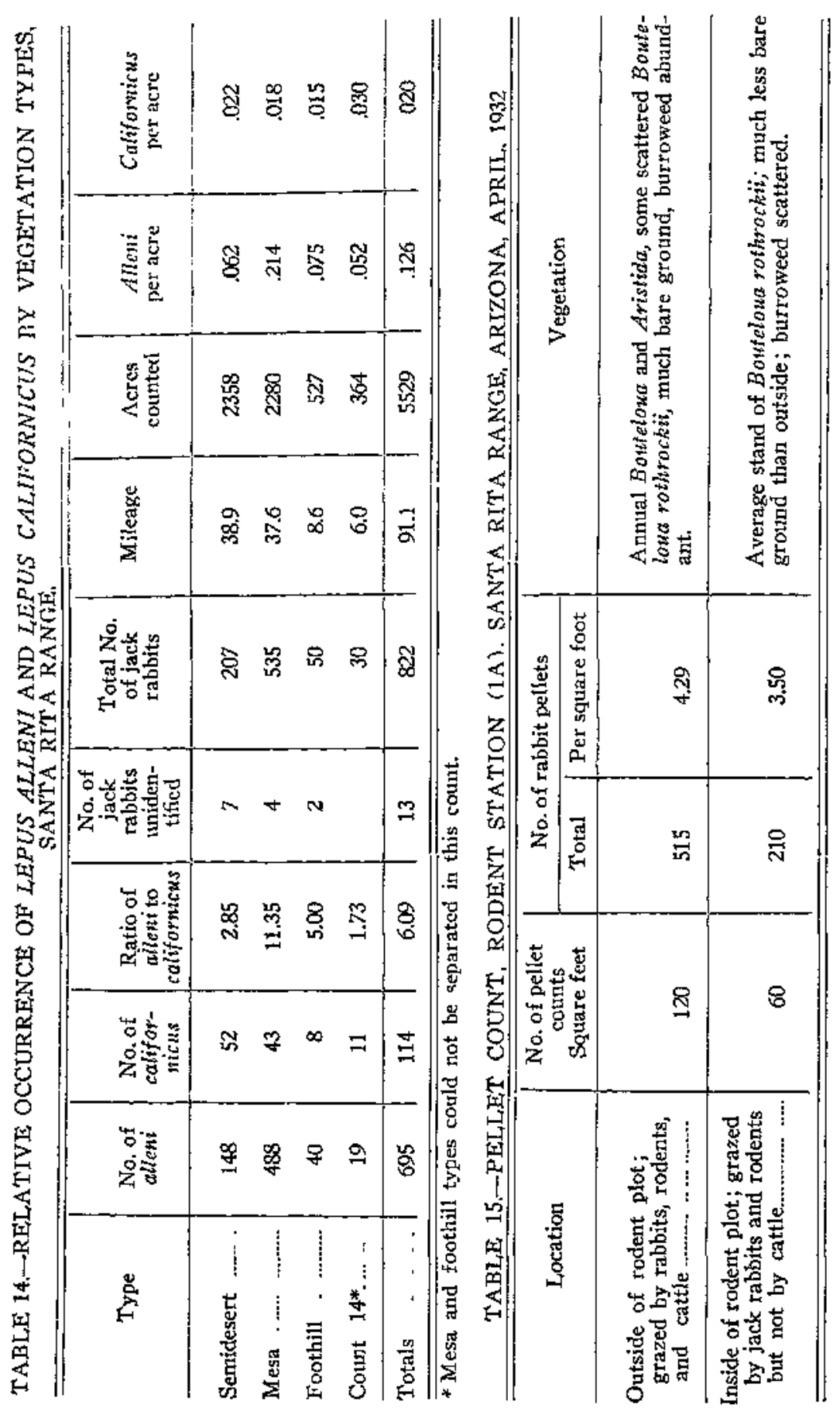


The pellets on 60 square feet were counted within the rodent-grazed plot, or cattle exclosure, where concentration might be expected; and the pellets on 120 square feet were enumerated in four places on the open land outside the fences. The counts were taken with a circulat hoop inclosing 1 sçuare foot of area. The hoop was placed on the ground, the pellets counted, the hoop picked up and the observer walked 50 feet, placing the hoop again, just as it came. This method gave counts from 1 square foot at 50-foot intervals along a line of 1500 feet. Results shown in Table 15 indicate no concentration of jack rabbits in the rodent-grazed plot, indeed, they show that jack rabbits do not occur so commonly in that area as they do in the less well-grassed tract outside. Later pellet counts, made during an tnusually dry period, show some concentration in the rodent-grazed plot.

A considerable number of peliet counts taken in a similar manner in the different vegetation types of the Sana Rita Range shows that jack rabbit pellets per unit (square foot) are considerably more abundant in the mesa type (2.45) than in the foothill $(0.75)$ or the semidesert (1.85). Individtal jack rabbits per unit (section) actually counted in the mesa type (149) were also considerably more abundant than in the foothill type (60) or in the semidesert type (54).

The number of jack rabbits actually counted in the mesa type was about $2 \pi / 2$ times as great as in the foothill type, while the number of jack rabbit pellets counted in the mesa type was about 3.3 times as great as in the foothill type. The number of jack rabbits actually counted in the semidesert type was slightly less than in the foothill type. Peilets counted in the semidesert type, however, were considerably more than twice as numerous as in the foothill type, showing a discrepancy between data on numbers derived from counts of jack rabbits and those derived from counts of pellets (Table 16).

TABLE 16-PEILET COUNTS AND RELATIVE ABUNDANCE OF JACK RABBITS BY VEGETATION TYPES ON SANTA RITA RANGE.

\begin{tabular}{|c|c|c|c|c|}
\hline Type & $\begin{array}{c}\text { Area } \\
\text { counted } \\
\text { squtare feet }\end{array}$ & $\begin{array}{c}\text { Jack rabbit } \\
\text { pellets }\end{array}$ & $\begin{array}{l}\text { Pellets per } \\
\text { square foot }\end{array}$ & $\begin{array}{l}\text { Jack rabbits } \\
\text { counted } \\
\text { per section }\end{array}$ \\
\hline 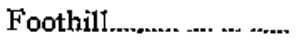 & 428 & 321 & .75 & 60 \\
\hline 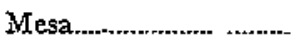 & 594 & 1454 & 2.45 & 149 \\
\hline Semidesert..................... & 569 & 1054 & 1.85 & 54 \\
\hline Totals ............................ & 1591 & 2829 & & \\
\hline Average....................... & & & 1.777 & \\
\hline
\end{tabular}




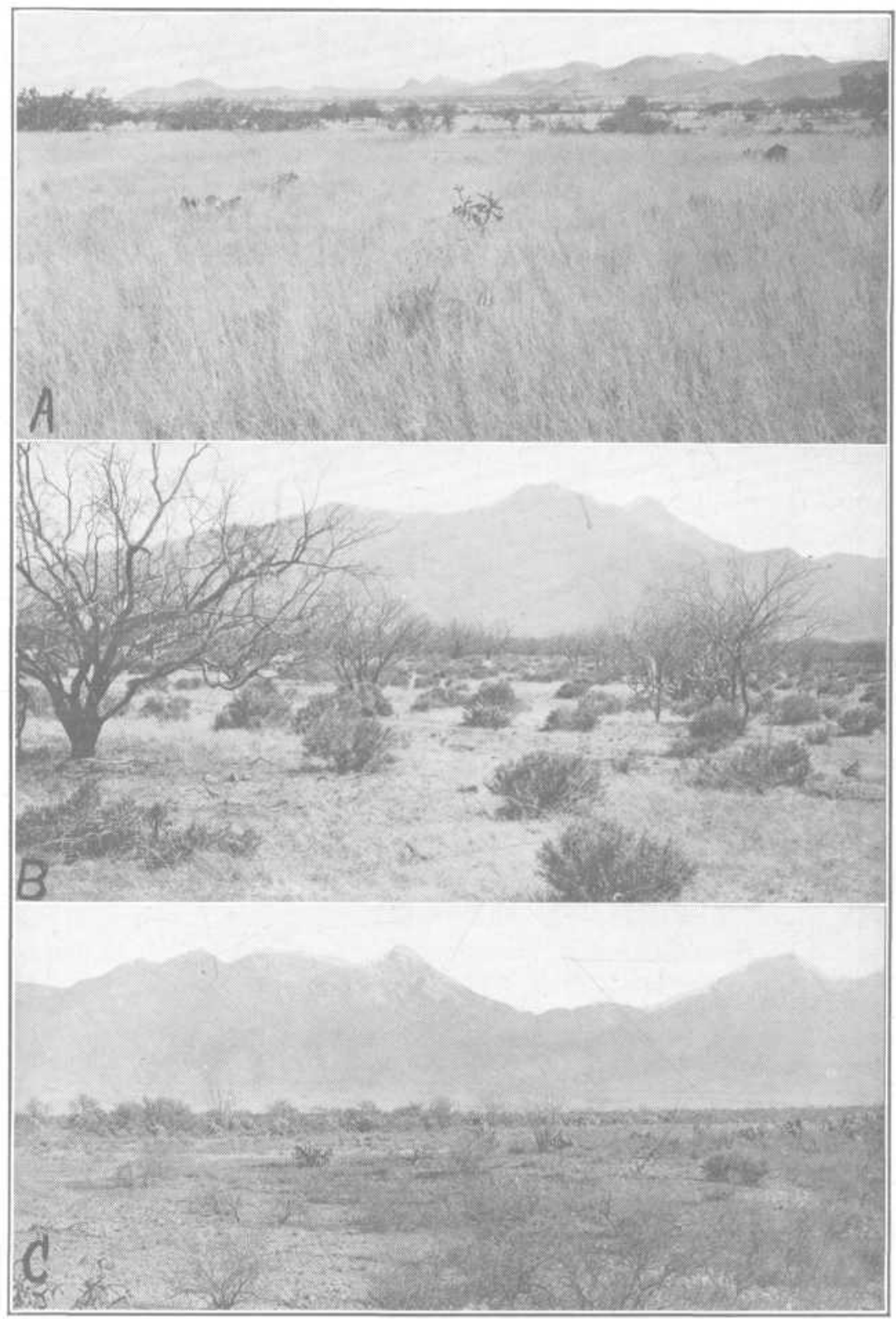

Plate 12.-Jack rabbit habitats, Santa Rita Range: A, Excellent grass in mesa type, where jack rabbits are only moderately abundant; B, sparse grass and abundant burroweed in mesa type-jack rabbits numerous; C, Semi-desert type where Arizona jack rabbits are more abundant than in the other types. 
It appears that jack rabbits are less easily seen th the burrow eed of the semidesert type than in the more open grass of the foothill type. The pellet counts suggest also that rabbits are less easily seen in the mesa type than in the foothill type, though the discrepancy is not so

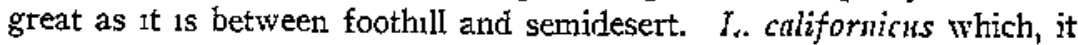
will be remembered, occurs more commonly in semidesert than in any other type, often escapes view by sneaking away in some shallow wash. I. alleni, on the other hand, runs characteristically across the washes and in the open. It is probable that califormicus evades notice more often than does alleni.

It is of interest that 2,829 jack rabbit pellets were found on 1.591 square feet of surface, counted at wide intervals over the Range, in all the main vegetation types. Four hundred and eighteen pellets weighed 8969 grams, or 0.21456 grams per pellet The pellets on a square-foot average 03815 grams, and on an acre 3661 pounds. For the 50,000 acres of the Range this amounts to $1,830,500$ pounds, or 915 tons. This Is approximately 30 times the weight of the living jack rabbits on the Range

\section{GRASS AND JACK RABBIT ABUNDANCE}

Contrary to our original opinion, detailed studies indicate that it is not true that jack rabbits are most abundant where the grass is best within their range. L. alleni reaches its maximum under conditions of moderate grass growth, as on the mesa type. It is less abundant both in the better-grassed foothill type and in the poorer-grassed semidesert type. Even in the mesa type, alleni is apparently less abundant where the stand of grass is excellent (Plate 12, A) than where the grass is of poorer stand and more mixed with weeds (Plate 12, B). (See Table 17.) L. califormicus is more abundant in the poorly grassed semi-desert type (Plate 12, C) than it is in erther the better-grassed mesa type or in the foothill type, where the best stand of grass in the region is to be found. This observation has a very practical bearing. It indicates that the stockman will make no mistake in conservative handiing of his range; that jack rabbits will not necessarly increase to consume the surplus of the grass left by cattle; and that if a range is allowed to run down, jack rabbits are likely to become more, rather than less, abundant, at least up to a certain point.

The reasons for the above findings are not entirely clear. It is not at all impossible, however, that the jack rabbit is more partial to some of the weeds and herbs of the secondary successions that accompany 
overgrazing. than to an exclusive diet of the clinax grasses. (See p. 541). Also there are more mesquites (on the Santa Rita) on the overgrazed areas. There is a possibility, also, that like so many rodents, the jack rabbits prefer open country with high visibility, to areas where the grass prevents seeing far.

TABLE 17-PELIET COUNTS, MESA TYPE, SANTA RITA RANGE, ARIZONA, APRIL, 1932.

\begin{tabular}{l|c|c|c}
\hline \multicolumn{1}{c|}{ Location } & $\begin{array}{c}\text { No of pellet } \\
\text { counts } \\
\text { Square feet }\end{array}$ & \multicolumn{2}{|c}{ No of rabbit pellets } \\
\cline { 2 - 4 } & 120 & 264 & 220 \\
\hline $\begin{array}{c}\text { In exceltent grass; } \\
\text { Eriopoda Station (2B) }\end{array}$ & 120 & 515 & 429 \\
\hline $\begin{array}{c}\text { In poor grass; } \\
\text { Rodent Station (1A). }\end{array}$ & Per square foot \\
\hline
\end{tabular}

* Good stand of Boutelota rothrockn, burroweed scattered. Annual Boufelout and $A$ sistida scattered.

† Much bare ground, burroweed abundant Anntal Boutelowa and Aistida, some Boutelous rothrockii, mostly scattered.

\section{ESTIMATED WEIGHT OF JACK RABBITS ON THE RANGE}

As estimated by us, there are some 7,500 jack rabbits on the 50,000 acres of the Santa Rita Range. The weight of these animals is of Interest. According to our counts, 1,085 of the rabbits are L. californicus. As the average californicus weighs 5.5 pounds, the total weight of this species on the range is 5,967 pounds. On the same basis there are $6,665 \mathrm{~L}$. alleni on the range. This species weighs 8 pounds on the average, the total weight for the Range being 53,320 pounds. The total weight of jack rabbits is 59,287 pounds. The 1,100 cattle on the Range at 750 pounds each would approximate 825,000 pounds in weight. Thus, the jack rabbits, on a liberal estimate, weigh but 7.18 percent as much as the cattle.

\section{ECONOMIC STATUS}

Jack rabbits may injuriously affect three great resources: farm crops, range, and forest.

\section{CROP DAMAGE}

Where cultivated crops are grown in jack rabbit country serious damage frequently occurs. The injury may be increased by an unusual abundance of the animals over a large territory, as has occurred repeat- 
edly in California, Oregon, Washington, ldaho, and other states, but of which we can find little evidence in southern Arizona. Serious damage may also occur, however, as a consequence of local concentration resulting directly from drouth and shortage of succulent food outside irrigated areas. Such concentrations have been unmistakable in southern Arizona in "bad" (drouth) years, where they occur mainly as nocturnal incursions from the surrounding "desert." Alfalfa, orchard and ornamental trees, young cotton, and many minor crops are thus attacked. In 1923 Taylor and County Agent C. B. Brown made a survey of jack rabbit damage in the Marana district, Pima County, Arizona. Eightyeight acres of young cotton had been completely destroyed, with loss estimated at $\$ 15,000$. The damage was confined to farms adjacent to hrush land, and within one-half mile of such cover The same year a Casa Grande, Arizona, farmer lost 20 out of 180 acres of cotton. A rancher at Servoss, Cochise County, Arizona, during this same exceptionally dry season lost 14 acres of alfalfa throtgh jack rabbits. After summer rains had produced abundant food on the desert, ranchers reported no further trouble.

Similar losses occur all over the West, as inclicated in reports by Jewett (Oregon), Palmer (California), Couch (Washington), and Preble (Oregon). The last-named definitely refers to the dry condition of the surrounding country as a cause of the jack rabbit raid on crops. Bailey reported from Oregon that "In fields of young alfalfa and grain the rabbits often take a large part of the crop or all of it unless fenced out. ... In a dry season, the loss from them is more serious than when there is more rain and more vegetation."

It seems clear that in cases of crop damage artificial control of rabbits must be exercised or adequate protection by fencing provided.

\section{RANGE DAMAGE}

A very large part of Arizona is devoted to grazing. Indeed, range lands occupy about 88 percent of the area of the State, and comprise some $64,000,000$ acres. Similar proportions hold for much of the western United States, where grazing is an important industry.

In southern Arizona, and doubtless in many other localities, always excepting areas where the prairie dog is abundant and uncontrolled, jack rabbits probably do more damage to range lands than any other gnawing animals. It is a remarkable fact, however, that few jack rabbits are found on the extensive and well-grassed Empire Ranch country, east of the Santa Rita Mountains, or the San Rafael Valley to the south, along the international boundary, while on the beautiful ranges 
of the Altar Valley the animals are plentiful along the washes. These areas, with or without jack rabbits, conservatively grazed by cattle, seem to refute, so far as the jack rabbit is concerned, the sweeping state ment quoted by Barnes (1926, p. 14) that "Not only have the ranges been over-stocked but the prairie dog and the jack rabbit have also been damaging the land until the best natural grass country in the United States has been aimost destroyed." Does not the jack rabbit get too much blame for the results which come primarily from over-stocking?

Nevertheless, figures already given, see pp. 516 to 521 , and 523 to 525 , clearly indicate that jack rabbits destroy an appreciable amount of forage. As aiready stated (p. 527) there is no evidence that mesquite is damaged by rabbits. On the contrary, mesquite has apparently increased substantially since 1900 on the Range and is probably a factor in crowding out the grass. The condition of vast areas in southern Texas, where mesquite and prickly pear have nearly taken the country, may be a warning for us. Mesquite and cholla are certainly increasing on many of our heavily grazed areas.

When winter range is poor and the green bases of the grasses short and diffcult for cattle to graze, rabbits can still feed on them and thus may further reduce the possibility of utilization by cattle. The damage to grasses would doubtless be more serious than it is were it not for the fact, confirmed by these studies, that jack rabbits at times of grass shortage turn increasingly to mesquite and cactus.

We are not, however, in position to say that jack rabbits reduce the carrying capacity of range lands in this region by 25 percent or any other figure. Local conditions are so various, and the problem so complex, that any such statement would be misleading. Problems of jack rabbit damage to range are local. Each community is a problem in itself. It will do little good to eliminate jack rabbits, even where they are superabundant, if an area is being persistently overgrazed by livestock.

\section{FOREST DAMAGE}

A number of references to rabbit damage in the forest have been made (see p. 511 et seq.). No reports have been received, however, of this sort of injury in the Southwest.

\section{VALUE OF JACK RABBITS}

Inasmuch as the jack rabbit has been generally considered, if not a pest, at least useless, it may prove surprising to see assembled the evidences of its positive value. Jack rabbits have proved to be valuable 
for their skins, for human food, as food for fur-bearers, and as a safety factor for game and domestic livestock.

The largest item is that of returns from skins, which but a few years ago could not be sold at any price. Sales in Washington State for the winter of 1928-1929 were estimated by the Biological Survey at 4,000 white-tailed jack rabbit skins at $\$ 1.15$ per pound, and 150,000 blacktailed jack rabbit skins at 75 cents per pound. In the United States, in $1929,8,000,000$ pelts were sold for about $\$ 2,000,000$. In Australia, in June, 1927, over 30,000,000 rabbit skins were marketed (Kinghom, pp. $211-213,1928$ ), nearly $£ 3,000,000$ being the return during that month for skins alone. While, as Kinghorn states, the various credits do not compensate for rabbit damage done, surely there is nothing against making a pest pay in cash as well as with its life for some of the injury it does.

Various Indian tribes long ago discovered methods of making warm sleeping robes from rabbit skins. Stich robes are found in burials of the ancient cliff and pueblo dwellers of the Soutliwest.

As food jack rabbits are not popular with the rural white population, but they are in some demand among the poorer classes and foreign elements of cities. Bailey in 1916 reported that Lepus c. wallawalla had been shipped to Portiand in large numbers at 10 cents each. Vorhies reports that in Salt Lake City (1910-1915) jack rabbits sold readily at 25 cents per head, and that large kills of a thousand rabbits made on winter holiday drives for charity were eagerly taken. In southern Arizona the poorer Mexican population consumes jack rabbits whenever they can be obtained. A large agrictltural project near Tucson some years ago found its fields seriously damaged by jack rabbits. The management solved the problem by providing the Mexican laborers with cheap .22 calibre rifles and ammunition at cost.

As a supplemental feed for hens, jack rabbit carcasses are valuable. The meat diet added to other rations produces eggs at an acceierated rate. While the American farmer may dislike to take the trouble to shoot jack rabbits on his fields morning and evening for his poultry this suggests itself to us as a feasible practice which would often pay good profits. At the same time control would be exercised precisely where and when most needed.

\section{THE JACK RABBIT A SAFETY FACTOR}

It seems clear that the existence of a fairly generous supply of jack rabbits affords some protection to wild game and domestic animals by diverting the attentions of coyotes and other carnivores. 
Some years ago Preble (1908, p. 212) called attention to a similar relation between rabbits, varying hares, and game in the AthabaskaMackenzie region. He said that many large game animals, and even sledge dogs, were destroyed by wolves when rabbits were scarce.

A significant interrelation of similar kind was emphasized a few years ago by Cabot (1912). In Labrador in the year 1905 mice of various species reached a peak of abundance. Predatory creatures of all sorts fed on the mice. Abundance of mice therefore tended to build up the ptarmigan and the caribow through diverting the attention of flesh-eaters from the game species. The next year the mice disappeared. The consequent change in the wild life was rematkable. The wolves attacked the caribou, and the predatory birds the ptarmigan, both game species being much reduced. The mouse population affected all the game, food, and fur species in the region.

Cabot also presents some significant information regarding the rabbit in Labrador. He writes that the rabbit (varying hare), the caplin, a fish of coastal waters, and the mouse exist mainly to feed their predatory superiors, and possess an importance quite beyond their apparent insignificance. In years of rabbit scarcity in Labrador the Indians do not hunt the districts where there are no lakes to provide a supply of fish. In these years the lynx, the chief rabbit hunter of them all, is said not to breed. The hardship of the rabbit's absence is felt also by the martens, by birds of prey, and by other hunting creatures. Thus it is that, as Cabot says ". . . one may well touch his hat with respect when the name of the Indians' 'Little White One' is mentioned."

Of course the values mentioned by Cabot are those of a primitive northern country, where great and apparent fluctuations in animal population are the rule. While the case is far different in our own Southwest, there is no doubt in our minds that, in small or moderate numbers, the jack rabbit will be of neutral or even beneficial status on all but cultivated lands.

A number of careful observers have noted increased coyote depredations following decrease in rabbit numbers. For example, a definite statement to this effect by Benjamin Lawton, chief game guardian and wolf bounty inspector for the Province of Alberta is quoted by Hewitt (1921, pp. 199-200). Hewitt also points out (p. 211) how the numbers of rabbits affect the grouse. He explains that in its normal haunts the goshawk preys on the rabbit and grouse. When rabbits are abundant the hawks increase in numbers and when the rabbits periodically disappear the hawks attack the grouse in greater numbers.

Bailey says (1928, p. 61), in the Carlsbad region of New Mexico, 
"Out over the dry flats and ridges only an occasional rabbit was seen, and their total numbers would probably not average more than three to a square mile of the valiey country. In this scattering and about normal abundance they are of little economic importance and may prove an asset rather than a liability, for they feed the coyotes, eagles, hawks, and owls and thus prevent more serious depredations on livestock and game."

Leopold (1931, p. 96) refers to the known importance of the snowshoe rabbit in diverting predators from more valuable game.

In 1930 a stockman on the Lembi National Forest told S. B. Locke that there were many more rabbits in the old days when coyotes were thick, than now. It was his opinion that the present scarcity of rabbits and sage grouse caused the coyote to live principally on sheep, so that even with fewer coyotes, the damage was proportionally greater. On the contrary, Foster is of the opinion that the removal of jack rabbits in the Congress Junction area, Arizona, has had no influence whatever in turning the attention of coyotes to sheep. He believes that the extent to which coyotes control rabbits or rodents is in direct proportion to the amount of domestic livestock. When sheep are available, coyotes will not eat many rabbits since it is much easier, he points out, for the coyote to kill a young lamb than to catch a jack rabbit.

Nevertheless, we feel that there is much evidence to indicate that a normal population of rabbits and rodents which form the food for a variety of flesh-eating birds and mammals is an important safety factor for quail, fawns, sheep, and calves.

\section{CONTROL}

\section{RABBITS IN AUSTRALIA}

An interesting and significant picture of what might happen in this country in the absence of natural checks on jack rabbits is afforded by the story of the introduction and increase of rabbits in Australia. Since this story fot the most part is unfamiliar to American farmers and stockmen, we have outlined it here.

The introduced rabbit which is such a pest in Australia is not a hare, but the rabbit from the Continent of Europe, Oryctolagus cuniculus (Miller, 1912, p. 485) secondarily introduced into England, South Africa, and elsewhere.

The exact date of the introduction of the rabbit into Australia is unknown. Kinghorn (1928, pp. 211-213) refers to the establishment 
and increase of rabbits introduced by Governor King as early as 1791 ; while Matthans (1921, p. 18) refers to an importation made by Thomas Austin of Barwon Park in 1859 as the first to become acclimatized on the mainland. Suffice it that the climate and soil of Australia suited the rabbits perfectly, and their natural enemies were too few and too weak to keep their numbers within reasonable bounds.

While at first the rabbits increased and spread very slowly, being the prey of eagles, hawks, and native cats (presumably Dasyurus), at length they" secured a firm footing and commenced to expand in a terrifying manner. In spite of all attempts at suppression, the rabbits steadily overran the country until, at present, almost the whole of the Continent is well within their grip.

By 1921 (Matthams) the total amount spent by the Australian Government approached $£ 200,000$ per year in addition to large sums spent by landholders and to the colossal losses suffered through the consumption and destruction of pasture and produce.

As the rabbit numbers increased the people were not idle, and vigorous attempts were made to bring the pest under control. At different times there were employed as major projects introduction of nataral enemies, disease, and various methods of eradication, including poisoning, digging out of dens, destruction of vegetation, and a bounty system of killing.

The Australian predators proving impotent in the face of the rising menace, many attempts were made to bring in the natural enemies of rabbits from Europe. At different times stoats, weasels, ferrets, and foxes were imported. None of these species was effective.

Stoats and weasels are well known to be bloodthitsty animals, killing more than they require to satisfy their wants. They proved serviceable, explains Matthams, especially in rocky and forest country, although they did not keep the rabbits suppressed to a satisfactory extent. Ferrets were extensively bred and released by thousands on Crown lands, espeially in New Zealand. While they kept certain areas fairly free from rabbits, they were suspected of more driving away of rabbits than actual destruction. In the seventies foxes were introduced into Victoria by the Melbotarne Hunt Club for sporting purposes. By 1921 thousands were roaming about Australia. Their principal food is rabbits.

In all these cases of introduced predators it is difficult to prevent their depredations on valuable life, including domestic poultry, lambs, native wild life, and introduced game. When rabbits became scarce the stoats, weasels, and ferrets turned to poultry yards and ground-nesting birds. In New Zealand they exterminated the introduced game 
where it was once plentiful. The fox, likewise, readily turned to lambs, poultry and bird hife. Apparently all these foreign predators have themselves become serious pests.

The bounty or "bonts" system was apparently given a thorough trial and it is reported that in 1887 bounties were paid on $27,000,000$ scalps in New South Wales alone. Between 1883 and 1888 (when the bonus system was discontinued) expenditures for bounties aggregated $£ 917,000$.

None of these various means was found superior in actual killing of rabbits to the laborious digging out of burrows, use of poison (strychnine, phosphorus,* arsenic, and poisonous gases) and elimination of cover practiced from the first.

In something like desperation the Government of New South Wales offered a reward of $£ 25,000$ (August 31,1888 ) to anyone who could demonstrate an effective means of exterminating rabbits (Matthams, 1921, p. 121). Although a good deal of activity was stimulated by this offer and a number of diseases introduced in a limited way they were not effective. There was always the chance, too, that the disease would spread to desirable wild life.

\section{BIOLOGICAL CONTROL,}

Principles of biological control as applying to prey-predator relations among vertebrates have received far less attention from research workers and wild life administrators than their importance deserves. In attempting to formulate our own opinions we have been much helped by the analogy between these prey-preciator relations among the vertebrates and bird-insect relations. Certain papers in the latter field by McA tee $(1920,1926,1927,1928,1931)$ have been particularly illuminating. We propose the following tentative principles, largely paraphrased from McAtee, which we believe to be applicable.

1. Predators almost invariably specialize on the most abundant or most easily accessible food supply.

This is a commonplace of field experience. When rabbits, rodents, or insects are superabundant, they will be given special attention by flesh-eaters. To a degree, at least, natural checks act automatically in a manner similar to the governor on a steam engine.

2. Predators must be judged on their average economic tendencies

It is of interest that phosphorts is or has been used in Australia, apparently extensively, in spite of complaints of damage to valuable wild life. This poison is so dangerous that in the United States its use is rigorously avoided if not prohibited. 
rather than on local activities and seasonal or otherwise exceptional behavior.

We are beginning to realize the error of appraising our "predatory" mammals on the basis of the most serious depredations of individual offenders. Snap judgments as to the true status of flesh-eating or other species either of birds or mammals, are almost sure to be wrong.

3. Control measures should not be applied to a whole species of predator on the basis of damage done locally. The proper remedy for local and sporadic depredations by flesh-eaters is local and temporary control.

The Biological Survey has repeatedly emphasized the need for confining control activities to particular linited localities. The necessity for this is increasingly realized, both from the standpoint of the biology of the situation, and of the economical use of State and Federal funds.

4. Rabbit, rodent, and insect control, aside from that applied by man, is due to a combination of all inimical factors - unfarorable climate, predators, parasites, diseases, and innate defects in the herbivores themselves - in other words, the whole envitonmental complex.

5. Probably the most useful function of predators is in their constant cutting down of the numbers of herbivores and insects in general, and not in their more spectacular services in the presence of rabbit. rodent, or insect plagues.

The value of biological controls in preventing animal plagues by nipping them in the bud is one that is frequently overlooked. A predatory animal may be an effective check when the numbers of its prey are small, whereas it may be of negligible influence if the food species breaks out of bounds and attains to plague status. In this connection see Hail $(1927$, p. 202).

6. Predators, where present in normal numbers, are a reasonably mobile force against rabbits, rodents, and insects and sometimes gather at the scene of an outbreak.

7. Predators are only one of the natural forces regulating the numbers of rabbits, rodents, and insects: it takes all the natural forces together to do the job.

Under the artificial conditions man has created it will sometimes be necessary for him to supplement the activities of all these natural forces and combat the rabbits, rodents, and insects directly to secure the degree of control necessary to commercial success.

8. Under normal conditions the natural enemies of rabbits, rodents, game, and insects live on population surpluses; the "interest" only is taken, the "capital" being left intact. 
9. Good economic tendencies are as satisfactory as any grounds for advocating the protection of predators.

In a real sense Huxley (in Elton, 1927, p. xiv) is right when he says the existence of enemies is a biological necessity to a species, as it prevents disastrous over population. So long as a normal number of natural checks is present, we probably need not be concerned, under ordinary conditions, about the breaking out of rabbit plagues. But it is a forlorn hope to depend on the flesh-eaters to "control" rabbits or rodents in the sense of eliminating all losses. In all probability control in this sense would seldom or never result from the natural enemies of a "pest" species. For the welfate of the predators is dependent on a continting supply of their food. Nevertheless, the services of the flesh-eaters in preventing the undue increase of a "pest" species may be appreciable, and fully warrant, in some localities, retaining the carnivores for their services in this regard.

Changes in conditions following upon occupation by man are responsible for modified and often problematic status. Ligon (1927, p. 49) writes that "Formerly when wild life had few other enemies, predatory animals exerted little influence on its abundance. In fact, predatory animals under primitive conditions were decidedly beneficial in preventing superabundance and in eliminating the weaklings and tunfit. Furthermote, they were potent factors in the process of distribution. But today we have an entirely different ratio of hunters to hunted. Then, too, game and game ranges have been greatly reduced, and predatory animals, naturally, harbor where the game finds protection from man. Compared with their prey, in the limited cover where the remaining game ranges, coyotes, because of more recent adaptations, are more numerous. Wildcats, which are serious enemies of game, are also numerous in most game covers." This discussion well illustrates the present-day point of view of the control man, the sportsman, and the livestock man.

There is little doubt that, as pointed out by Spencer in a letter to the writers, disturbance of vegetation through overgrazing, deforestation, farming or reclamation, is more far-reaching in its effects on rodent numbers than are the flesh-eaters. This observation accords also with that of Leopold, who has found that provision of cover and other environmental conditions is much more important to the conservation and increase of game than control of flesh-eaters.

Lantz (1917a, p. 17) has emphasized the need for better protection of coyotes, foxes, wildcats, badgers, skunks, minks, hawks, owls, eagies, and snakes, as enemies of rodent pests of the farm. He asserts that much of the damage now done by rodents is due to the unceasing war- 
fare naged against carnivorous animals, the fact that they destroy far more noxious rodents than they do useful animals being forgotten. $\mathrm{He}$ has pointed out, also $(1918$, p. 22) that many of our fur animals are an asset to the country, equal in value to our game, and that their destruction has often proved of no real help to game conservation.

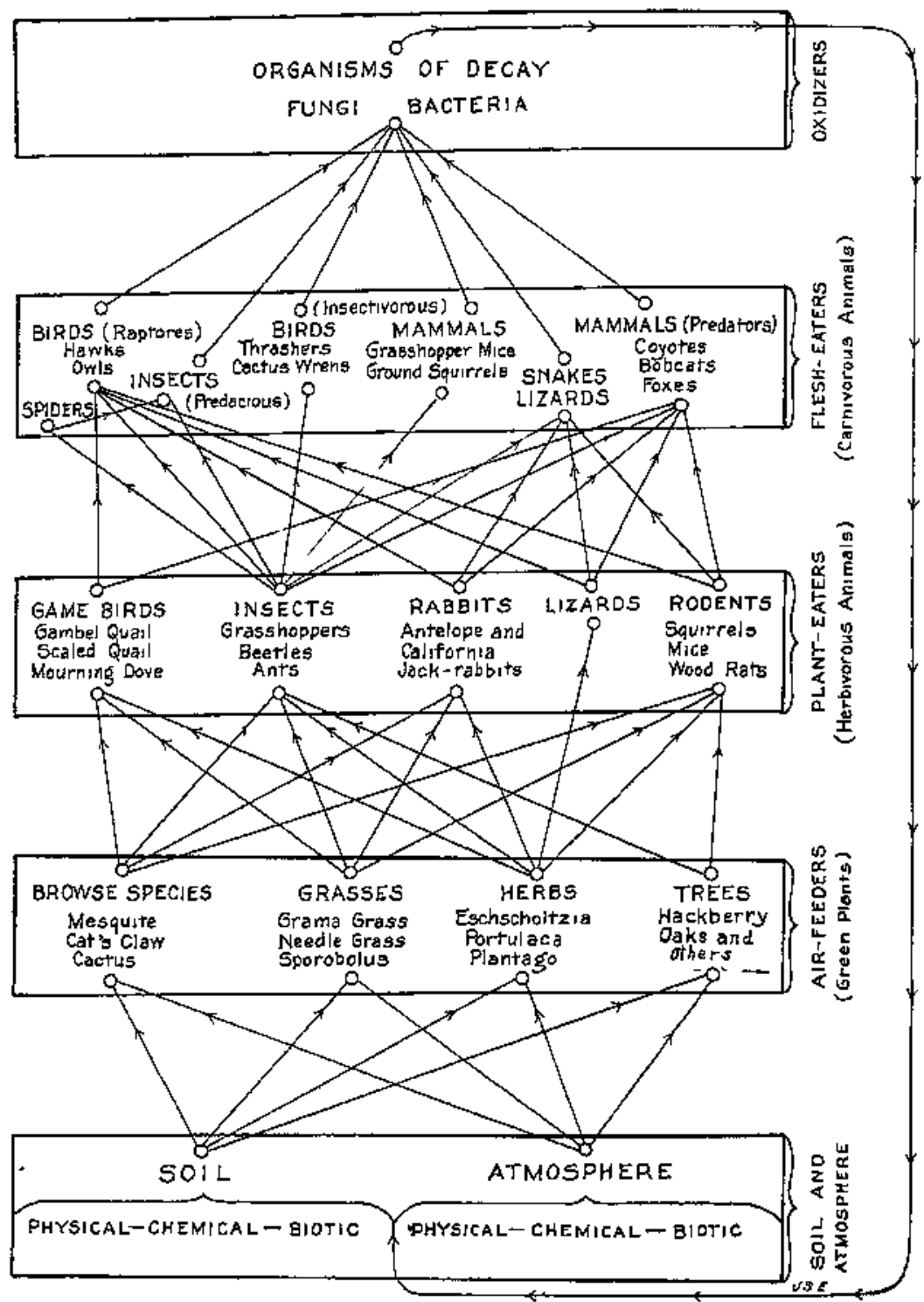

Fig. 5.-Tentative diagram of bio-physical complex on the Santa Rita Range. 
We sometimes hear the argument that it is essential to get rid of the coyote so that the game can become more abundant. Often equally emphatic arguments are heard that the coyote has no appreciable effect on rabbits; that killing the coyote will not result in appreciable rabbit increase. We feel it would be thoroughly inconsistent to urge that the removal of coyotes permits the appreciable increase of game, but not the appreciable increase of jack rabbits and other rodents, even if the coyote fed equally on game and rodents: but as a matter of fact, rodents, and especially rabbits, figure to a much greater extent in coyote diet than does game.

To our mind the evidence shows that where anything like normal conditions prevail, it is best not to try to exterminate either the jack rabbits or their predatory enemies. The policy of the Biological Survey and of some of the states concerned is in full accord with this conclusion. The presence of jack rabbits may appreciably relieve predatory pressure on desirable game and livestock. The presence of flesh-eating mammals and birds is a factor of unknown importance in preventing plagues of rabbits, rodents, and insects (Fig. 5).

\section{THE BALANCE OF NATURE}

Under original conditions the forces of nature, predators, parasites, prey, all the complicated physical, chemical, and biotic factors, were in equilibrium of a sort. Sometimes this was violently fluctuating, but nevertheless following an inexorable law of compensation. There is no question that in the realm of bio-ecology, as in physics and chemistry, for every action there is an invariable and inevitable and absolutely equal reaction. This balance of cause and effect must have held as long as the universe has been operating on uniformitarian as distinguished from catastrophic principles.

Much skepticism has been expressed, of late, of the reality of the balance of nature. We are of the opinion, however, that the phrase is pertinent and accurate. Nor can man affect the situation at all, in the sense of eliminating the balance. He has blithely and necessarily upset the original balance, and he can further disturb the present balance. In any case, a new balance of forces must ensue. He may abstract a weight here or put another there, but he can never destroy the balance any more than he can prevent the conservation of energy. The new balance may be more to his liking, or it may be extremely harmful to him. It is man's job to understand the balance well enough to be sure, when he changes it, that the new arrangement will be to his advantage- 
The fact that man as yet understands very little of the natural world is an excellent argument that he should be cautious in upsetting nature's arrangements.

Marsh has well said $(1898$, p. 143) "As often as we destroy the balance by deranging the original proportions between different orders of spontaneous life, the law of self-preservation requires us to restore the equilibrium, by either directly returning the weight abstracted from one scale or removing a corresponding quantity from the other. In other words, destruction must be either repaired by reproduction or compensated by new destruction in an opposite quarter."

This means that if we reduce the natural predatory enemies of jack rabbits for whatever reason, we shall probably have to plan for an increase in rabbits. Destruction necessitates further destruction. As repeatedly asserted by the Biological Survey and others conversant with the situation, extermination is not a justifiable objective. To paraphrase Romell slightly (1930, p. 842) we may say "Everything indicates that in the future the administration of natural resources will have to rely still more than now on natural equilibria." The best control program is that which interferes least with the orderly relationship of natural species, but which at the same time, helps to assure success to the agriculture, range management, and forestry on which man depends for his own existence.

\section{DIRECT METHODS}

It has long been recognized that direct control of the jack rabbit is one of the most difficult of all the control problems which trouble the farmers of the Southwest and the Federal and State agencies which attempt to help them. One reason for this is that in the mild climate of the Southwest rabbits do not concentrate in winter as they do in the more extreme northern climates, and so are much less easily poisoned.

Federal and State agencies have been working on these problems and have devised some good methods. Control must of course be adapted to local conditions. The isolated farm or small comminity surrounded by much wild land may be able to use poison alfalfa, but in the long run will probably find it cheaper to fence against the jack rabbit, or as previously suggested, to shoot the animals day by day and use the carcasses for pouitry feed. Rabbits killed in excess of present need may be preserved in our arid climate by immediately skinning, gutting, and hanging them up to dry.

Gilchrist has worked out a careful comparison of the relative costs of shooting with a .22 calibre tifle and of poisoning, as follows: 


\section{Shooting}

Labor of 1 man 8 days at $\$ 2.50$ per day $\$ 20.00$

$1,000.22$-calibre rifle cartridges at $\$ 5.00$ per thousand. 5.00

13 gallons gasoline at 25 cents per gallon used in car while travelling 191 miles shooting jack rabbits

1 gallon lubricating oil at 30 cents per gailon.

Total cost of shooting 859 jack rabbits.

Cost per rabbit shot.

\section{Poisoning}

Labor of 1 man 4 days removing stock and prebaiting. ..........\$10.00

Labor of 1 man 4 days placing poison.

$173 / 4$ ounces strychnine at 57 cents per ounce........................... 10.12

355 pounds of fresh alfalia for pre-bait at 1 cent per pound..... 3.55

355 pounds of fresh alfalfa for poison bait at 1 cent per pound. 3.55

Total cost of poisoning 962 jack rabibits.

Cost per jack rabbit poisoned

These demonstrations were on a comparable scale of size, and were in the same general region, near Willcox, Arizona. The cost of poisoning was more than $1 / 2$ cent higher per rabbit than the cost of shooting, or $161 / 2$ percent more expensive. This cost differential may result from failure to find all poisoned rabbits.

In connection with this excellent showing for the shooting method it may be pointed out that the use of poison has certain disadvantages. Not only may valuable livestock be accidentally poisoned, but harmless or beneficial wild life may occasionally be destroyed. Poisoning of pest species of animais has been advocated and practiced to a greatly increased degree in recent years, but the poisons and poison baits are not ordinarily specific and are very difficult to handle in a manner above criticism. Poison should be used only under supervision of State or Federal officers. Otherwise it may be expected that its abuse will eventually bring about the passage of strict legislation against the use of poison.

Since most cuitivated fields are already fenced against livestock, the expense of adding the necessary netting to make a rabbit-proof fence is not great. An effective, though not very permanent, job can be done with the cheapest material, common poultry net. Where the first cost can be met, a more durable net will pay in the long run. This fence must be tight to the ground, since the rabbits will crawl or even burrow 
under rather than go over. Two-inch mesh poultry net, 2 feet in height, is ordinarily sufficient to turn rabbits. Occasional inspection for entrance burrows will be necessary.

Rabbit drives, being spectacular (and, where shooting is a part of the drive plan, appealing to man's sporting or killing instinct) sometimes result in the destruction of impressive numbers of jack rabbits. Since this method is most successful where and when very dense rabbit poptlations occur, and since extreme over-poptation of jack rabbits is relatively rare in Arizona, it is not much advocated here. If it were not for the picnic and sports feature it would probably seldom be resorted to, for if all the man power used in a drive were paid for at day-labor wages, and the ammunition and gasoline used were charged against the project, driving would prove to be an expensive method of control.

We regret that it has been impossible for us to hit upon any readily applied formula which would tell just when control should be applied. We have wrestled long with this problem, but have been forced to conclude that information regarding the economics of industry and of wild life is not sufficient to permit of any simple statement.

As pointed out to the writers by Spencer, the time to determine optimum numbers of range-feeding rodents and rabbits is during the worst years, when animal damage is greatest. Just as stock should be regulated on a basis of the numbers a range can carry in the driest years, so attempts to limit the native vegetation feeders may well be guided in the same way.

If a stockman or rancher has a rabbit problem, he shotld examine the situation from the point of view, not alone of the damage done by the rabbits, but also the possible benefits. Often there will be no question whatever regarding the need for control. State and Federal offcials, including county agricultural agents and Federal leaders in todent and predatory mammal control. can be of great assistance and should be consulted whenever damage becomes serions.

Where the problem is not so simple, and there is a question whether jack rabbits are abundant enough and doing damage enough to warrant control, the benefit should in all cases be given the existing condition.

\section{A FUNDAMENTAL, PRINCIPLE}

In former days protection, with little reference to long-tinne results, was the magical word in conservation of assumed valuable game. In the same way extermination was the objective for control of alleged pest species.

The more scientific management programs of the present day require a readjustment of former aims. Protection of deer may be extremely 
harmful if a surplus population grows up and overconsumes the available feed. Extermination of alleged pests is so often attended with costs and difficulties that it must be abandoned as an aim of control.

The modern objective of game and wild life management is a nornal popratation of wild animals. Judicious interference by man will often be necessary to maintain optimum numbers. The question of what is the optimum number of a particular species will have to be settied in each locality on the basis of its actual and potential values, the damage it may do, and its often complex relationships, incinding the interest of man in that particular place. This is wild life management.

\section{SUMAIARY}

1. More and larger areas under natural conditions are needed for the study of range problems.

2. Jack rabbits (hares) are readily separable from all other rabbits by structural characters and habits. The antelope jack rabbit. l.pus alleni, is readily distinguishable by its long white-edged ears and white sides from the gray-sided jack rabbits, Lepus californicus ssp., which have black-tipped ears and gray sides. L. alleni averages 8 pounds in weight and $L$. c. eremicus 5.5 pounds.

3. There are no apparent secondary sexual characters in the jack rabbits.

4. Jack rabbits are admirably adapted structurally and also in behavior for successftil life in an arid environment.

5. Lepus alleni is chiefly Mexican in distribution, occurring within the United States in only a small part of southern Arizona. It inhabits somewhat open country chiefly below 4,500 feet altitude.

6. The Lepus californicus group of jack rabbits occurs over practically the whole of the western United States, from the upper Arid Tropical to the Transition Zone.

7. Lepus alleni shows some tendency to gregariousness, but in $L$. californicus there is little or no such tendency. There is no evidence of hybridization between the two species.

8. Daily movements of jack rabbits depend on food and shelter relations. Seasonal movements of relatively limited extent may take place, usually in accordance with available food.

9. The rump-flash is a spectacular feature of the antelope jack rabbit. 
10. The senses of hearing and smell in the jack rabbit are particularly keen. Toutch also, is probably sensitive. Sight is apparently less useful than the others.

11. The normal life span of jack rabbits is unknown.

12. The sex ratio is nearly balanced.

13. The breeding season of jack rabbits in southern Arizona is long, extending from January to September.

14. Lepus californicus produces more young per litter, average 2.24 (1-6), than L. alleni, average 1.93 (1-5). The litter averages vary by months, showing a correlation with average monthly precipitation. Prob. ably three or four litters are produced each season.

15. Jack rabbits probabiy scatter their young at or soon after birth, though occasional nests have been authentically recorded. The young are fully furred and active at birth.

16. Rabbit pressure may exercise a profound effect on plant associations. Man's disturbance of original conditions accentuates this situation, and is frequently the cause of difficulties.

17. Calculations indicate that it takes 15 Lepus alleni to eat as much valuable forage as one sheep, or 74 as much as one cow; and twice as many $L$. californicus as $L$. alleni to consume the same amounts.

18. In our experimental plots on the Santa Rita Range jack rabbits and rodents are apparently mainly responsible for holding the vegetation in a preclimax condition, preventing attainment of the climax grass stage.

19. Stomach analyses available indicate that 36 percent of the food of Lepus alleni is mesquite, and 45 percent grass; and that $L$. californicus consumes 56 percent of mesquite and only 24 percent of grass. On these analyses it appears that grass and mesquite together constitute 80 percent of all food of both species. Unfortunately stomach analyses do not give an adequate idea of weeds consumed. It is probabile these figures by themselves would lead one to seriously underestimate the rabbit's actual liking for and consumption of weeds.

20. The evident fondness of rabbits for grass when available probably favors the encroachment on grass ranges of mesquite, cholla cactus, weeds, and other species.

21. It is estimated that jack rabbits consume less than 3 percent of the potential production of grass on the Santa Rita Range. 
22. Jack rabbits are chiefly crepuscular and nocturnal.

23. Flesh-eaters, as the coyote, bobcat, and numerous other mammals, and a wide variety of hawks and owls, feed quite regularly on jack rabbit and under normal conditions help to prevent over-population.

24. Jack rabbits are commonly infested with parasites, of which Cuterebra larvae (warbles), ticks, and tapeworm cysts are most com1mon. Fleas are fairly abundant. Tularemia, to which humans are also susceptible, is the most important germ disease of rabbits. so far as known. There is little evidence that any of these materially affect the numbers of jack rabbits in southern Arizona.

25. The jack rabbit population in southern Arizona does not show extremes of variation. Fluctuations in numbers are more marked in regions of greater temperature extremes, but maxima or minima occur at different times in different localities.

26. Several methods of enumerating jack rabbits were tested and checked against each other. The mumber of these animals on the 50,000 acres of the Santa Rita Range is probably between 5,000 and 10,000. The jack rabbits are estimated to weigh only 7 percent as much as the cattle on the Range.

27. Pellet-count methods were developed as a means of checking on the relative abundance of jack rabbits on different areas.

28. Jack rabbits tend to be more abundant in open weedy areas than in the best grass areas.

29. Jack rabbit effects, even if neutral at other times, may be important during the driest season of the year; jack rabbit pressure on vegetation during the driest season of the driest year of a cycle is likely to produce results more far-reaching than in any other year or combination of years. Numbers should be regulated with this in mind.

30. Jack rabbits are of value for skins, as food for man and carnivores, and as a safety factor for game and livestock.

31. The experience of Australia should serve as a warning of what might happen if the natural predator checks on rabbit increase were completely removed. The best control program is one which interferes least with the orderly relationships of natural species, but which, at the same time, helps to assure success of the agriculture, range management, and forestry on which man depends for his own existence. Natural equilibria must be increasingly relied upon in administration of natural resources. 
32. Consumption of grass by jack rabbits varies inversely with consumption of mesquite and cactus. Conservative handling of grazing ranges, including stocking for the worst years rather than the best or even the average years, and retention of a normal population of flesheaters, may ordinarily be counted on to obviate serious rabbit injury. Under conditions of overgrazing and of misapplied control of predators. there is almost sure to be a jack rabbit and rodent problem.

33. Rabbit drives in Arizona are not of great value for direct control. Poisoning and careful work under certain conditions with a .22 calibre rifle are reasonably effective, with the cost and other advantages in favor of shooting. For crop protection rabbit-proof fence is best and cheapest.

34. In small or moderate numbers the jack rabbit may be of neutral or even beneficial status on all but cultivated lands. 


\section{BIBLIOGRAPHY}

Abbey, George.

1909.-The balance of nature and modern conditions of cultivation. 278 pp., illus. London.

Allan, H. H.

1926.-The vegetation of Mount Peel, Canterbury, New Zealand. Trans. New Zealand Inst. 56: 37-51; 57: 73-89.

Anthony, $\mathrm{H}$. E.

1928.-Field book of North American mammals. 625 pp., illus. New York.

Arthur, S. C.

1928. - The fur animals of Lottisiana. La. State Dept. Cons. Bul. 18, 433 pp., illus.

Ashbrook, F. G.

1930.--Rabbits for food and fut. 176 pp, ,llus. New York.

Bailey, Vernon.

1905.-Biological survey of Texas. North Amer, Fauna No. 25, 222 pp, illus.

1928 - Animal life of the Carlsbad Cavern. Amer. Soc. Manmal. Monog. 3, 195 pp., illus. Baltinore.

Baker, F. S., Korstian, C. F., and Fetherolf, N. J.

1921 --Snowshoe rabbits and conifers in the Wasatch Mountains of Utah. Ecology 2. 304-310.

Barnes, W. C.

1926.-The story of the range. U. S. Dept. Agr., 60 pp., illus (Reprint Senate Hearings Comm. Public Lands, 69 th Cong., 1 st Session, pursuant S. R. 347.)

Bird, R. D.

1930.-Biotic communities of the aspen parkland of central Canada. Ecology $11: 356-442$.

Birdseye, C.

1912. - Some common mammals of western Montana in relation to agriculture and spotted fever. U. S. Dept. Agr. Farmers' Bul. 484, 46 pp., illus.

Burnett, W. I.

1926.-Jack rabbits of eastern Colorado. Cir 52, Office State Entom., Colo. Agr. College. $18 \mathrm{pp}$, illus.

Burr, J. G. 1930.-Year book on Texas conservation of wild life. $110 \mathrm{pp}$, illus Austin.

Cabot, W. B.

1912.-In northern Labrador, 292 pp. Boston.

Cary, Merritt.

1911.-A biological survey of Colorado. North Amer. Fauna No. 33, 256 pp., illus.

Cattell, J. McKeen.

1929.-P sychology in Ametican science, 70 (1815), 335-347.

Clements, F. E.

1916.- Plant succession; an analysis of the development of vegetation. Carnegic Inst. Wash. Pulbl. 242, 512 pp., illus.

Couch, L. K.

1930.-Introduced European rabbits in the San Juan IsIands, Washington. Jour. Mammal. 10:334-336.

Dayton, W. A.

1929.-The best forage species not always handicapped by over-grazing? Forest Worker, p. 26. 
Dixon, J.

1925.-Food predilections of predatory and fur-bearing mammals. Jour. Mammal, $6: 34-46$.

1926.-Dressed weights of muskrats, beavers, and jack rabbits. Jour. Mammal. 7. $133-134$.

Elliot, W., and Crichton, A.

1926.- II. Report on the effect of the addition of mineral salts to the ration of sheep. In Elliot, W., Orr, J. B., and Wood, T. B. Investigation of the mineral content of pasture grass and its effect on herbivora. Jour. Agr. Sci. 16: 65-77.

Elton, C. S.

1927.-Animal ecology. 207 pp., illus. New York.

1929.--Ecolog:, Animal. Encyl. Brit., ed. 14, 7: 915-924.

Farrow, E. P.

1925a.-On the ecology of the vegetation of Breckland. VIII. Views relating to the probable former distribution of Callumo heath in England. Jour. Ecol. 13: 121-137.

1925b.-Plant life on East Anglian heaths. 108 pp., illus, Cambridge.

Ferris, C. F.

1916.-Notes on Anoplura and Mallophaga, from mammals, with descriptions of four new species and a new variety of Anoplura. Psyche 23. 97-120.

Flower, W. H., and Iydekker, R.

1891.-An introduction to the study of mammals living and extinct. 763 pp., illus, London.

Forsling, C. I.

1924.--Saving livestock from starvation on southwestern ranges. U. S. Dept. Agr. Farmers' Bul. 1428, 22 pp., illus.

Francis, E.

1922,-Tularaemia, a new disease of man. U. S. Pub. Health Serv., Hyg. Lab. Bul. 130,87 pp., illus.

1925.-Tularaemia. Jour. Amer. Med. Assn. 84:1243-1250.

1928. -Tularaemia in rabbits and other animals as related to human health. Jour. Wash. Acad. Sci. 18: 108.

Godden, W.

1926--III. Report on the chemical analyses of samples of pasture from various areas in the British Isles. In Elliot, W, Orr, J. B., and Wood, T. B. Investigation of the mineral content of pasture grass and its effect on hetbivora. Jour. Agr. Sci. 16:78-88.

Goldman, E. A.

1930.-The coyote-arch predator. Jour. Mammal. 11 : 325-334.

Grange, W. B.

1932:-Observations on the snowshoe hare, Lepus americanus phaeonotus Allen. Jour. Mammal. 13: 1-19.

Griffiths, D.

1928--Prickly pear as stock feed. U. S. Dept. Agr. Farmers' Bul. 1072, 19 pp. illus.

Grimnell, J., Dixon, J., and Linsdale, J. M.

1930.- Vertebrate natural history of a section of northern California through the Lassen Peak region. 594 pp., illus. Berkeley. 
Hall, E. R.

1927.-An outbreak of housemice in Kern County, California. Univ, Cal. Pubt. Zool. 30: 189-203.

Hanmond, J.

1925.-Reproduction in the rabbit ... with foreword and chapter on the formation of the corpus lutewn by F. $H$. A. Marshall. 210 pp., illus. London.

Hanson, $\mathrm{H}$. C.

1929.-Types of grazing land in Colorado. The Cattleman, March, pp. 57-63.

Henderson, W. C.

1930.- The control of the coyote. Jour. Mammal. 11: 336-350.

Henry, W. A. and Morrison, F. 8.

1923.-Feeds and feeding a handbook for the student and stockman Ed. 17. 691 pp., illus. Madison.

Hershaw, $H$. W., and Birdseye, $C$.

1911.-The mammals of the Bitterroot Valley, Montana, in their relation to spotted fever. U. S. Dept. Agr. Cir. No. 82, 24 pp., illus.

Hewitt, C. G.

1921.-The conservation of the wild life of Canada. 344 pp., illus. New York.

Iliili, R. R.

1928.-The war against the desert. Jour. Forestry 26: 91-93.

Horton, J.

1930---Birds and mammals killed by forest fires. The Mrurrelet, $11: 22$.

Howell, A. B.

1923.-Periodic fluctuations in the numbers of small mammals. Jort. Mammal. 4: $149-155$.

Hull, T, G.

1930.-Diseases transmitted from animals to man. 350 pp., illus. Baltimore.

Huntington, E.

1931. -The Matamek conference on biological cycies, 1931. Science, 74: 229-235.

Johnson, C. E.

1925.-The jack and snowshoe rabbits as swimmers. Jour. Mammal. 6: 245-249.

Johnson, F. R.

1923. Tree planting in the Great Plains region. U. S. Dept. Agr. Farmers' BuI, 1312, 32 pp, illus.

Joyner, N. F.

1929.-The prairie hare. Yellowstone Nature Notes, 6: 1-2.

Keilogg, V. L. and Ferris, G. F.

1915. The Anoplura and Mallophaga of North American mammals. Leland Stanford Jr. Univ. Publ. Univ, Ser. 92 pp., illus.

Kinghorn, $\mathrm{J}$. R. 1928.-Faunal problems. Anstraliar Zoologist, 5: 211-213.

Kittredge, .

1920.-Forest planting in the Lake States. U. S. Dept. Agrr. Dept. Bul. 1497, $87 \mathrm{pp}$., illus.

Klugh, A, B.

1926.-The life of the varying hare. Nature Mag. 7:228-230.

Lantz, D. E.

1905 -Kansas mammals in their relation to agriculture. Kans. Agr. Exp. Sta. Bul. 129, pp. 331-404, illus.

1908. -The rabbit as a farm and orchard pcst. U. S. Dept. Agr. Yearbook Sep. 452, 13 pp., illus. 
1916.-Cottontail rabbits in relation to trees and farm crops. U. S. Dept. Agr. Farmers' Bul. 702, 12 pp., illus.

1917a.-Destroying rodent pests on the farm. U. S. Dept. Agr. Yearbook Sep. 708,18 pp., illus.

1917b.-Raising Belgian hares and other rabbits. U. S. Dept. Agr. Farmers' Buil. 496,16 pp., illus.

1918.-Rodent pests of the farm. U. S. Dept. Agr. Farmers' But. 932, 23 pp., illus.

Leopold, A.

1931. - Report on a game survey of the north central states. 299 pp., iflus. Madison.

Lewis, F. J., Dowding, E. S., and Moss, E. H.

1928.-The regetation of Alberta. II. The swamp, moor and bog forest vegetation of central Aiberta. Jour. Ecol. 16: 19-70.

Ligon, J. S.

1927.-Wila life of New Mexico; its conservation and management. 212 pp., illus. New Mexico State Game Comm., Santa Fe.

Lundberg, Gustav.

1929,- - Vânt Villebrád. Haren (Our wild game, The hare). Skogen, 16:144151.

Lyon, M. W., Jr.

1904.-Classification of the hares and their allies. Smith. Misc. Coll. 45 : 321447, illus.

Marsh.

1898.-The earth as modified by human action. 629 pp. New York.

Matthams, J.

1921.-The rabbit pest in Australia, 264 pp., illus. Melbourne.

McAtee, W. I.

1920.-Abundance of periodical Cicadas, diverting attacks of birds from cuttivated fruits. The Auk, 37: 144-145.

1926.-The role of vertebrates in the control of insect pests. Smith. Inst. Annual Rept., 1925 : 415-437, illus.

1927.-Averages are fundamental in economic ornithology. Bird-Lore, 29 : $97-99$.

1928.-Birds and other checks upon insects. Sci. Mon. 27: 77-80.

1931.-Control of insects by birds. Wilson Bul, $43: 28 \div 29$.

Miller, G. $S$.

1912.-Catalogtte of the mammals of western Europe (Europe exclusive of Russia) in the collection of the British Musetum. $1019 \mathrm{pp}$. London.

Moseley, E. L.

1927.-Our wild animals. 310 pp., illus. New York.

Nelson, E. W. 1909.-The rabbits of North America. North Amer. Fauna No. 29, 314 pp,

1918.-Wild animals of North America, pp. 385-612, i11us. Nat. Geogr. Soc.. Wash.

Orde-Powlett, N.

1923.-Rabbits and sycamores. Jour. Camb. Univ. Forest. Assn. 2: 12-13.

Palmer, T. S. 1897.-The jack rabbits of the United States. U. S. Dept. Agr. Bul. 8,88 pp.,
illus. 
Pearson, G. A.

1931.-Recovery of western yellow pine seedlings from injury by grazing animals. Jour. Forestry, $29: 876-894$.

Preble, E. A.

1908. - A brological investigation of the Athabaska-Mackenzie region. North Amer. Fautna No, $2 \%, 574$ pp., illus.

Romell, L. G.

1930.-Forest soil researcin in relation to forestry with particular teference to the Northeast. Jour. of Forestry $28: 841-848$.

Roosevelt, $T$.

1904.-The wilderness hunter. 296 pp., illus. New York.

Sampson, A. W.

1928.-Livestock husbandry on range and pasture. $41 \mathrm{t}$ p., illus. New York.

Seton, E. T.

1909-Life-histories of northern animals. An account of the mammais of Manitoba. Vol. II, Flesh-eaters, pp. 677.1267, illus. New York.

1929.-Lives of game animals. Vol. 4, Pt. 2, pp. 441-949, illus. New York.

Soper, J. D.

1921. -Notes on the snowshoe rabbit. Jour. Mammal. 2: 101-108.

Spiker, J.

1931.-A biological reconnaissance of the Peterboro swamp and the Labrador pond areas. Roosevelt Wild Life Bul. 6: 1-151.

St. Clair-Thompson, G. W.

1928. The protection of woodlands by natural as opposed to artificial methods. 223 pp., ilitis. London.

Stead, D. G.

1928.-The rabbit menace in New South Wales. Dept. Agr. X. S. W. 72 pp., illus.

Stephens, F.

1906.-California mammals. 351 pp., tlius. San Diego.

Stoddard, H. L.

1931.-The bobwhite quail, its habits, preservation and increase. 560 pp., illus. New York.

Tansley, A. G.

1922. Studies of the vegetation of the English chalk. II. Early stages of re-development of woody vegetation on chalk grassland. Jour. Ecol. 10: $168-177$.

Taylor, W. P.

1930.-Methods of determining rodent pressure on the range. Ecology $11: 523$ 542.

Thornber, J. J.

1911.-Native cacti as emergency forage plants. Ariz. Agr. Exp. Sta. Bul. 67, 457-508, illus.

Vorhies, C. T., and Taylor, W. P.

1922. - Life history of the kangaroo rat, Dipodomys spectabilis spectabilis. U. S. Dept. Agr. Bu1, 1091, 40 pp., iltus. (Also Tech. Bul. 1, Ariz. Agr. Exp. Sta.)

Warren, E. R.

1910.-The mammals of Colorado. 300 pp., illus. New York.

Wilson, C. P.

1928 a.-Factors affecting the germination and growth of chamiza (Atriplex conescens). New Mex. Agr. Exp. Sta. Bul. 169, 3-29, illus.

1928b,-Forage plants destroyed by small animals. The Cattleman, $15: 27-29$. 
